\title{
"Lady Alcumy": Elizabethan Gentlewomen and the Practice of Chymistry
}

\author{
Sienna Louise Latham
}

A thesis submitted to the Victoria University of Wellington in fulfillment of the requirements for the degree of Master of Arts in History

Victoria University of Wellington

2010 


\begin{abstract}
This thesis explores the advent of gentlewomen's chymical activities in Elizabethan England. In the sixteenth century, chymistry gained widespread currency under Queen Elizabeth I. This thesis argues that the queen's significant chymical interests contributed to her iconography, thereby bridging England's previously discrete chymical and female realms. It shows that Elizabeth's influence and fundamental societal changes enabled women, beginning with the gentry, to acquire and apply chymical knowledge. Four case studies highlight the queen's impact on her female subjects through an examination of primary manuscript and printed sources. The Protestant gentlewomen Grace Mildmay, Mary Sidney Herbert, Margaret Hoby and Margaret Clifford may first have encountered chymistry in the manifestation of their religious beliefs through charitable healing, but they developed their knowledge in very different ways. Evidence of their engagement with chymical practitioners and writings provides context for their activities. Shared motivations led to divergent practices, indicating that chymistry in Elizabethan England took as many forms as there were practitioners. This thesis asserts the crucial importance of community to early modern chymists, noting courtly links and overlapping social circles. It contributes to limited historiography on Elizabethan alchemy as well as female alchemists.
\end{abstract}




\section{Contents}

Abstract ii

Acknowledgments iv

List of Figures $v$

List of Abbreviations $v i$

Note on Transcription vii

Introduction 1

1. Gnosis and Praxis: Queen Elizabeth I and Her Chymical Court 16

2. Grace Mildmay 44

3. Noble Nurse of Learning: Mary Sidney Herbert 69

4. Margaret Hoby 91

5. Margaret Clifford and the Elizabethan Chymical Community 115

$\begin{array}{ll}\text { Conclusion } & 140\end{array}$

Bibliography 146 


\section{Acknowledgments}

I am grateful to my supervisor, Glyn Parry, for his invaluable guidance and feedback, which have shaped my novitiate enthusiasm into a measured assessment of five remarkable women during the past year. I am also appreciative of Steve Behrendt's extremely helpful advice during the revision process. Many thanks to Jayne Archer and M.E. Warlick, who kindly shared their work on women and alchemy and encouraged mine. My family and friends have been a source of unfailing support throughout the research and writing process, and I am particularly grateful to my husband Chris for his patience while I transformed our home into a very specialized library. 


\section{List of Figures}

1. George Baker, "Lady Alchymya,"

The newe Jewell of Health (1576), frontispiece.

2. John French, "Pelican vessel,"

The Art of Distillation (1651).

3. "Gentlewomen Chymists and the Courtly Chymical Community," Compiled by the author and Chris McDowall (2010). 


\section{List of Abbreviations}

$\mathrm{BL}$

$C M S$

$C P R$

$C S P D$

$O D N B$

TNA

SP
The British Library

Calendar of the Manuscripts of the Most Honourable the Marquis of Salisbury, Preserved at Hatfield House, Hertfordshire

Calendar of the Patent Rolls Preserved in the Public Records Office

Calendar of State Papers Domestic

Oxford Dictionary of National Biography

The National Archives of the United Kingdom

State Papers 


\section{Note on Transcription}

I have retained original spelling and grammar when quoting from primary documents. For clarity's sake, expansions of uncommon or unclear contractions are indicated in brackets. Where secondary editions of primary documents have been utilized, I adopted the modernizing conventions employed by their editors. 


\section{Introduction}

Historians have downplayed Queen Elizabeth I's interest in and patronage of chymistry, but it is no coincidence that the monarch who so carefully managed her iconography drew comparisons with Lady Alchymia. ${ }^{1}$ This thesis examines the advent of female chymical activities during Elizabeth's reign, arguing that the historical paucity of women chymists was not a function of the art itself. Rather, it reflected cultural norms and prescribed gender roles. English society limited the nature and extent of female chymical involvement, but the transitional Tudor period would fundamentally alter this relationship. Though not the first English queen associated with the philosopher's stone, Elizabeth's influence heralded a shift in the activities deemed acceptable for women, allowing them to encroach upon the previously forbidden chymical realm in a manner consistent with both their accepted social functions and strongly held religious beliefs. ${ }^{2}$

Modern assumptions about alchemy have led to its marginalization in contrast to the utilitarian precision of chemistry. William Newman and Lawrence Principe have shown that early modern practitioners failed to draw a clear and consistent distinction in their linguistic treatment of the two terms. ${ }^{3}$ During the sixteenth century alchemy referred not only to the transmutation of base metals into gold (chrysopoeia) but also a quest to find the fabled elixir or philosopher's stone, medical alchemy (iatrochemistry), practical and theoretical chemistry, and spiritual alchemy later adopted by nineteenth-century occultists and, in a purely psychological context, C.G. Jung. To ensure clarity and guard against imposing contemporary views on my subjects, in this thesis I adopt Newman and

\footnotetext{
${ }^{1}$ On the neglect of chymistry in biographies of the queen, see, for instance, Patrick Collinson, "Elizabeth I (1533-1603)," ODNB, Oxford University Press, 2004; online edn., May 2008 [http://www.oxforddnb.com/view/article/8636, accessed 21 June 2010]; and works by J.B Black, Christopher Haigh, Joel Hurstfield, Paul Johnson, Sir Arthur Salusbury MacNalty, Anne Somerset, Agnes Strickland and Milton Waldman. Exceptions can be found in chymically focused works.

2 The French Queen Isabella, consort of Edward II, was associated with both a work of iatrochemistry and an "Elixir of Youth." See Jayne Elisabeth Archer, "Women and Alchemy in Early Modern England" (PhD dissertation, Cambridge University, 1999): 1.vii.

${ }^{3}$ William R. Newman and Lawrence M. Principe, "Alchemy and Chemistry: The Etymological Origins of a Historiographic Mistake,” Early Science and Medicine, Vol. 3, No. 1 (1998): 33, 35, 38.
} 
Principe's suggested terminology: first, by using "chymistry... when discussing the general development of the discipline"; second, by describing specifically "transmutational pursuits" as chrysopoetic rather than alchemical; and third, by employing, when applicable, precise terminology such as "iatrochemistry" and "spagyria", a Paracelsian expression that refers to the chymical process of dissolution and coagulation. ${ }^{4}$ Such specificity elucidates the variety in early modern chymical practice among both women and men.

We need only examine the history of chymistry to find a significant female presence in the royal art: as historical practitioners and emblematic symbols, and through links to the natural world and domestic sphere. My research into the earliest chymists benefits from prior work by historians like Frank Sherwood Taylor, Raphael Patai and P.G. Maxwell-Stuart, who acknowledged the prominence of women in the Egyptian, Chinese and Indian traditions. ${ }^{5}$ Indeed, as Jane Miller has asserted, "women were important to alchemy both as founders and adepts and as providers of an essential ingredient thought to ensure its success". 6 The first and most famous Egyptian practitioner, Maria Prophetissima or Maria the Jewess, likely lived between the first and third centuries. She combined practical experience and theoretical wisdom and gave her name to one of her inventions, a double boiler still widely used and known today as a bain-marie. Like the Virgin Mary in the Koran, Maria was associated with Miriam, sister of the biblical Moses. ${ }^{7}$ This parallel testifies to a longstanding relationship between religion and chymistry that the subjects of this thesis maintained.

\footnotetext{
${ }^{4}$ Ibid., 64.

${ }^{5}$ F. Sherwood Taylor, The Alchemists (London: Scientific Book Club, 1950): 25-66; Raphael Patai, The Jewish Alchemists: A History and Source Book (Princeton: Princeton University Press, 1994), Pt. 2; P.G. Maxwell-Stuart, The Chemical Choir: A History of Alchemy (London: Hambledon Continuum, 2008): 4-5, 24, 37. See also Cathy Cobb and Harold Goldwhite, Creations of Fire: Chemistry's Lively History from Alchemy to the Atomic Age (New York: Plenum Press, 1995): 46-7; Lama Anagarika Govinda, Foundations of Tibetan Mysticism (New York: Samuel Weiser, 1969): 56-7.

${ }^{6}$ Jane A. Miller, "Women in Chemistry," in Women of Science: Righting the Record, eds. G. Kass-Simon and Patricia Farnes (Bloomington: Indiana University Press, 1993): 302.

${ }^{7}$ Patai, The Jewish Alchemists, 71, 74.
} 
Women also feature prominently in chymical language and imagery, a logical extension of the discipline's emphasis on reproduction and creation. Through the fourthcentury chymist Zosimos, who preserved Maria's writings and addressed his own works to Theosebeia, his soror mystica, we learn that gendered balance has been fundamental to chymical theory since inception: "Join the male and the female, and you will find what is sought". ${ }^{8}$ These feminine and masculine principles could manifest in a variety of ways: as wife and husband, adept and novice, queen and king, patroness and would-be client, and sister and brother. ${ }^{9}$ Lyndy Abraham and Leah DeVun have shown that even the philosopher's stone itself garnered hermaphroditic comparisons, at once both genders and neither. ${ }^{10}$ Michael Maier, a seventeenth-century occultist and counselor to Emperor Rudolf II, later attempted to justify to his contemporaries the prominence of a female figure like Maria with the kind of gender fluidity we will see in representations of Queen Elizabeth, describing "this courageous female warrior" as "endowed with a clearly virile spirit". 11

The portrayal of chymical concepts as women maintains a tradition of female allegorical representations popularized during the Middle Ages. From Dame Nature to Alchymia, we find no shortage of intellectual constructs clothed in the female form. Joseph Addison first hypothesized in 1721 that grammar was to blame; in Latin and the Romance languages, abstract nouns typically take the feminine gender. ${ }^{12}$ While true, the comparative lack of interest in personifying masculine nouns undermines his theory. Barbara Newman has suggested that "the logic of representation virtually demanded feminine figures". ${ }^{13}$ Although plentiful in the medieval period, these intermediary

\footnotetext{
${ }^{8}$ Ibid., 66. Zosimos was quoting Maria.

9 Archer, "Women and Alchemy," 8.

${ }^{10}$ Lyndy Abraham, A Dictionary of Alchemical Imagery (Cambridge; Cambridge University Press, 1998): 98-9; Leah DeVun, "The Jesus Hermaphrodite: Science and Sex Difference in Premodern Europe" in Journal of the History of Ideas, Vol. 69, No. 2 (2008): 193-218, esp. 194.

${ }^{11}$ Patai, The Jewish Alchemists, 76-7.

${ }^{12}$ Barbara Newman, God and the Goddesses: Vision, Poetry and Belief in the Middle Ages (Philadelphia: University of Pennsylvania Press, 2003): 36.

${ }^{13}$ Ibid.
} 
Christian goddesses all but disappeared during the early modern era, with the noteworthy exception of the marginalized esoteric tradition that included alchemy. ${ }^{14}$ The fifteenthcentury illuminated manuscript Aurora consurgens exemplifies this tradition, drawing parallels between scripture and chymical imagery. ${ }^{15}$

Another parallel pertinent to this thesis is the representation of the labor or opus mulierum (the toil or work of women) in chymical emblems. From the fourteenth century chymists had associated their art with "women's work", pointing to similarities between chymistry and the mundane activities that occupied housewives every day. ${ }^{16}$ M.E. Warlick has noted a profusion of quotidian imagery, with women engaged in domestic tasks such as cooking and laundering intended to illustrate steps in the Great Work. ${ }^{17}$ Indeed, many of the techniques seekers of the philosopher's stone utilized were developed and honed in the kitchen. These images remind us that the domains of women and chymistry intersect in two crucial places: the natural world and the household sphere.

Nature's personification as a woman gave mankind implicit permission to exploit her resources, as when practicing chymistry. ${ }^{18}$ Janus-like Dame Nature had two faces: as beneficent mother, she catered to our most primal needs, freely supplying sustenance and shelter; in an instant, though, her countenance could darken, shifting allegiance to chaos and disorder. ${ }^{19}$ In this guise she represented the unpredictable forces behind destructive storms, droughts, plagues and famines. Both metaphors catered to the possibility of

\footnotetext{
${ }^{14}$ Ibid., 305.

${ }^{15}$ Marie-Louise von Franz, ed., Aurora Consurgens: A Document Attributed to Thomas Aquinas on the Problem of Opposites in Alchemy (London: Routledge \& Kegan Paul, 1966). See, for example, p. 35, which echoes Proverbs 3:15-18 almost verbatim.

${ }^{16}$ The Opus mulierum et ludus puerorum was first published in De alchimia opuscula complura veterum philosophorum... (Frankfurt, 1550). See Lynn Thorndike, History of Magic and Experimental Science, Vol. 4 (New York: Columbia University Press, 1941): 547.

${ }^{17}$ M.E. Warlick, "The Domestic Alchemist: Women as Housewives in Alchemical Emblem" in Alison Adams and Stanton J. Linden, eds., Emblems and Alchemy (Glasgow: Glasgow Emblem Studies, 1998): esp. 26-7; and M.E. Warlick, "Moon Sisters: Women and Alchemical Imagery" in Alexandra Lembert and Elmar Schenkel, eds., The Golden Egg: Alchemy in Art and Literature (Berlin: Galda und Wilch, 2002): 183-98.

See, for example, Michael Maier, Atalanta fugiens (Frankfurt, 1617).

${ }^{18}$ See Carolyn Merchant, The Death of Nature: Women, Ecology, and the Scientific Revolution (San Francisco: Harper \& Row, 1980): xvii, 2 and passim; Newman, God and the Goddesses, 316.

${ }^{19}$ Chymist John Hester utilized similar imagery. See his The first part of the key of philosophie (London, 1580); Archer, "Women and Alchemy", p. 10.
} 
gaining power over Nature. As a woman, she was fertile and creative, capable of being dominated, controlled or exploited. This perception of the natural world as female pointed to assumptions about women's status in relation to men.

The subjugation of women had its roots in the scriptural Garden of Eden. For the church fathers, the creation story confirmed female inferiority. Ruled by her heart rather than her head, the "weaker vessel" required the guidance of male reason. Contemporary anatomy also supported the doctrine of female subordination. ${ }^{20}$ Early modern medical tracts attested to women's biological inferiority; Fontanus confirmed the Hippocratic assertion that "the matrix is the cause of all those diseases which happen to women". ${ }^{21} \mathrm{He}$ and his colleagues interpreted the womb as a flaw rather than a perfecting characteristic, drawing attention to the etymological link between hysteria and the Greek hysterikos, or womb, with female-only conditions like "suffocation of the mother" and "the green sickness". 22 The fairer sex would be viewed as imperfect versions of men - mere vessels for sustaining the growth and development of children — until the 1590s, when developments in anatomy rendered this judgment false. ${ }^{23}$

At the same time, women's association with Nature, whose form recalled their own, underscored their possession of secrets unavailable to even the most powerful, skilled and learned of men: those relating to female health and reproduction. The distinctions that exist for us today between science and superstition did not feature in the early modern landscape, as Keith Thomas has demonstrated. ${ }^{24}$ Standing at the intersection of life and death, women appeared to possess occult powers that inspired equal parts awe and fear in

\footnotetext{
${ }^{20}$ Londa Schiebinger, The Mind Has No Sex?: Women in the Origins of Modern Science (Cambridge: Harvard University Press, 1991): 178-88.

${ }^{21}$ Quoted in Kate Aughterson, Renaissance Woman: A Sourcebook: Constructions of Femininity in England (London, Routledge, 1995): 61.

${ }^{22}$ See, for instance, Edward Jorden, A brief discourse of a disease called the suffocation of the mother (London, 1603).

${ }^{23}$ Schiebinger, The Mind Has No Sex?: 178.

${ }^{24}$ Keith Thomas, Religion and the Decline of Magic (Oxford: Oxford University Press, 1971).
} 
men. ${ }^{25}$ Given their susceptibility to the devil's wiles, this supposed affinity for mysterious powers recalls Eve's Fall.

These views provide background for Nature's frequent alignment with scripture as the other sacred book worthy of investigation and potentially a source of divine revelation. ${ }^{26}$ Early pictorial representations of the goddess appear fully clothed; she welcomes the attention of natural philosophers, who have much to learn from this mysterious, wise figure. ${ }^{27}$ Later, we find her in a state of undress, sometimes entirely nude, her secrets exposed and accessible. Chymists in particular drew a clear distinction between nature and their art, which could pervert, perfect or surpass the natural world. ${ }^{28}$ Like medicine, alchemy constituted a perfective art that aimed to create an end not found in Nature. The profusion of base metals in the earth proved that Dame Nature rarely produced the philosopher's stone, whereas the true alchemist always succeeded.

Feminist historians and critics have suggested male natural philosophers used chymistry to unlock women's biological secrets and demystify nature. David Noble, for instance, theorized that their underlying goal was an arrogation (and, indeed, an abrogation) of distinctly feminine powers such as procreation. ${ }^{29}$ Just as metals grew in the womb of the earth, influenced by the heavens, so too did the chymist develop metals in his own vessel or matrix, observing occult stellar influences. As such he epitomized the Renaissance notion of the human body as microcosm to the macrocosmic world. If men could perform acts of creation without the presence or assistance of women - as

\footnotetext{
${ }^{25}$ Anthony Fletcher, Gender, Sex and Subordination in England 1500-1800 (New Haven: Yale University Press, 1995): 232-3.

${ }^{26}$ Peter Harrison, The Bible, Protestantism and the Rise of Natural Science (Cambridge: Cambridge University Press, 1998): 45.

${ }^{27}$ Barbara Obrist, "Nude Nature and the Art of Alchemy in Jean Perréal's Early Sixteenth-Century Miniature" in Chymists and Chymistry: Studies in the History of Alchemy and Early Modern Chemistry, ed. Lawrence M. Principe (Sagamore Beach: Science History Publications, 2007): 115-7. See also Barbara Obrist, "Visualization in Medieval Alchemy" in HYLE: International Journal for Philosophy of Chemistry, Vol. 9, No. 2 (2003): 131-70.

${ }^{28}$ See Merchant, The Death of Nature, xix; William Newman, Promethean Ambitions: Alchemy and the Quest to Perfect Nature (Chicago: University of Chicago Press, 2004): 4, 17.

${ }^{29}$ Quoted in Penny Bayer, "From Kitchen Hearth to Learned Paracelsianism: Women and Alchemy in the Renaissance" in Mystical Metal of Gold: Essays on Alchemy and Renaissance Culture, ed. Stanton J. Linden (New York: AMS Press, Inc., 2007): 366.
} 
Paracelsus claimed to create life with his homunculus - they had further proof of the vast gulf between the sexes. ${ }^{30}$ Thus the subjection of women related to the desire by men to appropriate their perceived powers.

Early modern prescriptive texts defined marriage and motherhood — preferably to at least one son - as a woman's ultimate achievements. ${ }^{31}$ They claimed that a virtuous wife was chaste, silent and obedient to her husband, hinting at a vested interest in male honor and sexual ownership. ${ }^{32}$ Unconventional women risked accusations of witchcraft, promiscuity or scolding when they stepped out of bounds, the stigmatized "other" in contrast to the behavior represented as appropriate. ${ }^{33}$ As Laura Gowing has pointed out, these conduct books imply that "female disobedience is a problem caused by male incompetence and that female subjection is natural". ${ }^{34}$ The fact that the authors of such books recognized a need to prescribe behavior implies that the boundaries were not already in place. As subsequent chapters will show, in practice, although chastity, silence and obedience contributed to her reputation, they did not wholly characterize a respectable

\footnotetext{
${ }^{30}$ See Hildegard Elisabeth Keller, "Seeing 'Microcosma': Paracelsus's Gendered Epistemology" in Paracelsian Moments: Science, Medicine \& Astrology in Early Modern Europe, eds. Gerhild Scholz Williams and Charles D. Gunnoe (Kirksville: Truman State University Press, 2002): 93-115; William R. Newman, "Alchemy, Domination and Gender" in Noretta Koertge, ed., A House Built on Sand: Exposing Postmodernist Myths About Science (Oxford: Oxford University Press, 1998): 216-26; Margaret J. Osler, "The Gender of Nature and the Nature of Gender in Early Modern Natural Philosophy" in Judith P. Zinsser, ed., Men, Women, and the Birthing of Modern Science (De Kalb: Northern Illinois University Press, 2005): 71-85.

${ }^{31}$ See Fletcher, Subordination, esp. Ch. 1. On conduct books, see Suzanne Hull, Chaste, Silent \& Obedient: English Books for Women, 1475-1640 (San Marino: Huntington Library, 1982); Naomi J. Miller, "Hens Should Be Served First': Prioritizing Maternal Production in the Early Modern Pamphlet Debate" in Debating Gender in Early Modern England, 1500-1700, eds. Cristina Malcolmson and Mihoko Suzuki (Houndmills: Palgrave Macmillan, 2002): 161-84; Ann Rosalind Jones, "Nets and bridles: early modern conduct books and sixteenth-century women's lyrics" in The Ideology of Conduct: Essays on Literature and the History of Sexuality, eds. Nancy Armstrong and Leonard Hennenhouse (London: Methuen \& Co., 1987): 39-72; Jacqueline Eales, Women in Early Modern England, 1500-1700 (London: UCL Press, 1998): Ch. 4. See also specific conduct books: Edward Gosynhyll's Schole house of women (1541), Thomas Tusser's $A$ hundred good points of housewifery (1557), The worckes of Thomas Becon (1564), and Robert Cleaver's $A$ godlie forme of householde gouernment (1598).

${ }^{32}$ Fletcher, Subordination, 25-9.

${ }^{33}$ See Reginald Scot, The discouerie of witchcraft (London, 1584); James VI of Scotland, Daemonologie (Edinburgh, 1597); D.E. Underdown, "The Taming of the Scold: the Enforcement of Patriarchal Authority in Early Modern England" in Anthony Fletcher and John Stevenson, eds., Order and Disorder in Early Modern England (Cambridge: Cambridge University Press, 1985): 116-36; Heidi Breuer, Crafting the Witch: Gendering Magic in Medieval and Early Modern England (New York: Routledge, 2009), Ch. 1, esp. p. 6, and Ch. 4, pt. III, on maternal misappropriation ("witch's mark") in the representation of witches.

${ }^{34}$ Quoted in Fletcher, Subordination, 103.
} 
woman. Awareness of acceptable conduct enabled some ladies to test and transcend theoretical limits in emulation of their queen.

Women's powers were at their peak in the domestic sphere. As the organizers and maintainers of household order, women, particularly gentlewomen and the nobility, were accorded what today may seem an unexpected degree of authority within the confines of their own homes. From childhood girls learned practical skills: cooking, cleaning, mending, gardening, child-rearing, healing, distillation, hospitality and, in the case of the gentry, estate management. They effectively controlled the domestic food supply and maintained their family's health with medical knowledge. She may have been subordinate, but the early modern English housewife was expected to exhibit efficiency and competence as well. ${ }^{35}$ The skills required of these wives and mothers belied the commonly held beliefs that reason prevailed only in men or that women, ruled by their passions, could not grasp complex concepts and processes. Many served as healers to their family and neighbors, as few could afford the services of physicians. Folk remedies passed along the distaff line from mother to newly married daughter in the form of recipe books that paralleled a long tradition of male "books of secrets". ${ }^{36}$ Both contained medical receipts and gender-specific technical information. ${ }^{37}$

Female medical practitioners, midwives and specialists in women's health played a vital role in the history of medicine. ${ }^{38}$ However, organizations such as London's Royal College of Physicians, founded in 1518, sought to maintain their own social and financial

\footnotetext{
${ }^{35}$ Ibid., 173-4, 233.

${ }^{36}$ Lynette Hunter, "Women and Domestic Medicine: Lady Experimenters, 1570-1620" in Women, Science and Medicine, 1500-1700: Mothers and Sisters of the Royal Society, eds. Lynette Hunter and Sarah Hutton (Thrupp: Sutton Publishing, 1997): 95.

${ }^{37}$ See William C. Eamon, Books of Secrets and the Empirical Foundations of English Natural Philosophy, 1550-1660 (Ann Arbor: University Microfilms International, 1986): 39-41 and passim.

${ }^{38}$ See, for instance, Schiebinger, The Mind Has No Sex?, pp. 104-12; Deborah E. Harkness, "A View from the Streets: Women and Medical Work in Elizabethan London" in Bulletin of the History of Medicine, Vol. 82, No. 1 (2008): 52-85; Margaret Pelling and Charles Webster, "Medical Practitioners" in Health, Medicine and Mortality in the Sixteenth Century, ed. Charles Webster (Cambridge: Cambridge University Press, 1979): 179-80, 186-7; and Doreen A. Evenden, "Gender Differences in the Licensing and Practice of Female and Male Surgeons in Early Modern England” in Medical History, Vol. 42, No. 2 (1998), pp. 194-216.
} 
status by controlling and condemning their competitors. ${ }^{39}$ They promoted a tripartite hierarchy of physicians, surgeons and apothecaries that excluded and thus marginalized wise women, midwives and other unlicensed medical practitioners. Deborah Harkness has convincingly argued that organized systems of urban health care included early modern women working under the aegis of parishes and hospitals; she identified 305 unlicensed female practitioners in London between 1560 and 1610, fewer than ten percent of whom the College prosecuted. ${ }^{40}$ Even in the relatively regulated urban areas there existed a wide range of options for the sick, catering to the medical and financial needs of every class. Regardless of claims that unlicensed physicians were unskilled, evidence points to a lively market for their more affordable services. For example, Lauren Kassell has shown that self-taught astrologer-physician Simon Forman saw several hundred repeat patients in 1596 and $1597 .^{41}$ As Margaret Pelling has asserted, early modern medical practice "was neither well organized nor firmly controlled". 42

The fluid boundaries delineating appropriate behavior for women during Queen Elizabeth's reign would enable them to practice chymistry. A variety of changes in the sixteenth century contributed to the rise of female chymists in England. By closing convents and selling land to fund England's university system, Henry VIII restricted female access to knowledge, necessarily shifting their education to the household sphere where natural philosophy also found a home. ${ }^{43}$ Women may not have been allowed to

\footnotetext{
${ }^{39}$ See Pelling and Webster, "Medical Practitioners," pp. 165-235; Lauren Kassell, Medicine and Magic in Elizabethan London: Simon Forman: Astrologer, Alchemist, and Physician (Oxford: Oxford University Press, 2007); and John T. Young, Faith, Alchemy and Natural Philosophy: Johann Moriaen, Reformed Intelligencer, and the Hartlib Circle (Aldershot: Ashgate, 1998); Schiebinger, The Mind Has No Sex?, 10412; Merchant, The Death of Nature, 153; and Lucinda Beier, Sufferers \& Healers: The Experience of Illness in Seventeenth-Century England (London: Routledge \& Kegan Paul, 1987): 16.

${ }^{40}$ Harkness, "A View from the Streets," 56, 58-9 and passim. See also Rebecca Laroche, Medical Authority and Englishwomen's Herbal Texts, 1550-1650 (Aldershot: Ashgate, 2009): 2-4.

${ }^{41}$ Kassell, Medicine and Magic,143-4. See also the breakdowns of his consultations and treatments in the 1590 s on $129,154-5$.

${ }^{42}$ Margaret Pelling, "Medical Practice in Early Modern England: Trade or Profession?" in Wilfrid R. Prest, ed., The Professions in Early Modern England (Beckenham: Crook Helm, 1987): 104.

${ }^{43}$ Deborah E. Harkness, "Managing an Experimental Household: The Dees of Mortlake" in Isis, Vol. 88, No.

2 (1997): 247-62; Schiebinger, The Mind Has No Sex?, 13.
} 
attend a university, but many believed a virtuous, well-rounded lady benefited from a little learning. Both botany and, significantly, chymistry were considered feminine subjects worthy of study on account of their enduring association with women's work. ${ }^{44}$ The overlap in the raw materials, equipment and techniques of these fields puts into context female pursuit of chymical knowledge and experience long before their efforts gained official sanction and recognition.

Crucially for the subjects of this thesis, printed herbals, which tied household activities to the natural world surrounding them, reveal the changing perception of a small portion of female healers during Elizabeth's reign: charitable gentlewomen. With their detailed illustrations and descriptions of each plant's utility, these books appealed to literate women who made use of this knowledge in their culinary, medicinal and artistic endeavors. William Turner, the "father of English botany", made a point of excluding “euery old wyfe" from his mid-century herbal's intended audience, but John Gerard's 1597 publication included a non-royal, contemporary woman. ${ }^{45}$ Gerard contrasted the charitable medical practice of Anne Wylbraham, "a worshipfull gentlewoman", with the avaricious efforts of "the beggarly rabble of witches, charmers, \& ...couseners". ${ }^{6} \mathrm{He}$ recognized that gentlewomen like Wylbraham would utilize his Herball, and he supported their efforts gladly. My subjects, too, embraced the respectable combination of spiritually motivated charity and medicine. Gerard's dichotomy draws attention to the importance of status, suggesting that Elizabeth's close ties to natural philosophy first impacted female members of the gentry. His herbal highlights another important transition embodied by the queen herself: the representation of a real woman in place of intangible goddess figures.

\footnotetext{
${ }^{44}$ Schiebinger, The Mind Has No Sex?, 27, 241.

${ }^{45}$ Whitney R.D. Jones, "William Turner (1509/10-1568)," ODNB, online edn. [http://www.oxforddnb.com/view/article/27874, accessed 10 September 2010]; William Turner, The Seconde Parte of VVilliam Turners Herball (Cologne, 1562), sig. 3v.

${ }^{46}$ John Gerard, The Herball or Generall Historie of plantes (London, 1597): 288. See Laroche, Medical Authority, 12, 21-2.
} 
The pervasiveness of chymistry in early modern culture cannot be overstated.

Charles Nicholl has pointed out that, during Queen Elizabeth's reign, “alchemy was very much there at the time: in the air, on the page, a mode of perception". ${ }^{47}$ As a part of everyday life, chymical symbols, principles and practices appeared in what to modern eyes seem unexpected places - for instance, in portraits of the queen, on New Year's gifts from her subjects and among the royal employees, as I will discuss. James Campbell has contextualized William Cecil's backing of chymical projects throughout his life, supporting Glyn Parry's assertion that courtly Elizabethans took an abiding interest in occult philosophy and, more specifically, chymistry. ${ }^{48}$ However, the notion of chymistry as an elite field belies its transcendence of geographical, gender, age and class differences. The anonymous 1526 text Gloria Mundi claims that the prima materia, the substance from which the philosopher's stone is formed, is "found in the country, in the village, in the town, in all things created by God... Rich and poor handle it every day. It is cast into the street by servant maids. Children play with it". ${ }^{49}$ Chymistry threaded through the fabric of life for ordinary people, not merely those who identified as alchemists. ${ }^{50}$

In the following chapters I explore limited primary evidence and secondary analysis of female chymists during Queen Elizabeth's reign, engaging with the intersecting histories of alchemy, medicine, women and religion. My sources range from Mary Sidney Herbert's published works to Margaret Hoby's private diary, including medical receipts passed from mother to daughter, as in the case of Grace Mildmay, political records related to the queen's chymical patronage, Margaret Clifford's correspondence from a fellow chymist, and the herbals and medical texts that disseminated elite knowledge.

\footnotetext{
${ }^{47}$ Charles Nicholls, The Chemical Theatre (London: Routledge \& Kegan Paul, 1980): 106.

${ }^{48}$ See James Campbell, "The Alchemical Patronage of Sir William Cecil, Lord Burghley" (Master's thesis, Victoria University of Wellington, 2009); and Glyn Parry, The Arch-Conjuror of England: John Dee and Magic at the Courts of Renaissance Europe (New Haven: Yale University Press, forthcoming 2010): Ch. 7.

${ }^{49}$ Quoted in John Read, From Alchemy to Chemistry (Mineola: Dover Publications, 1995): 30.

50 Archer, "Women and Alchemy," 3.
} 
In general, female chymists, like their male counterparts, varied significantly in their backgrounds and application of knowledge. My subjects, however, reveal unanticipated similarities. Connected by marriage and courtly associations, they moved in the same social circles. In contrast to Deborah Harkness's assertion that London formed the center from which spokes of early scientific study radiated, Elizabeth's court served as the nexus for these ladies. ${ }^{51}$ Like the queen herself, each woman favored the Protestant emphasis on direct engagement with the divine. Religion informed all aspects of their lives, including chymistry, which they employed in different ways. While these women exemplify the variety in Elizabethan female chymical practice, they should not be considered the only representatives. Given the importance of the written word in this research, literacy constitutes a fundamental criterion for determining chymical affiliation. The resulting bias means that I am overlooking members of the lower classes.

This thesis supplements increasing historiographical attention to female chymists. Penny Bayer has recounted scholarship on women and alchemy in a comprehensive essay, detailing a number of biographical accounts of early modern English and European women with chymical interests. ${ }^{52}$ For instance, Donald Dickson's investigation of English chymists Thomas Vaughan (1621-1666) and his wife Rebecca (d. 1658) indicates that the two engaged in practical experiments together. ${ }^{53}$ Susanna Åkerman has written at length about Queen Christina of Sweden (1626-1689), and Tara Nummedal's forthcoming work on Anna Maria Zieglerin (1550-1575) recounts the German chymist's execution at the age of twenty-five for her esoteric pursuits. ${ }^{54}$ Linda Pollock edited writings by Lady Grace Mildmay (ca. 1552-1620) that reveal "extensive forays into Paracelsian medicine"

\footnotetext{
${ }^{51}$ See Deborah Harkness, The Jewel House: Elizabethan London and the Scientific Revolution (New Haven: Yale University Press, 2007).

${ }^{52}$ Bayer, "From Kitchen Hearth," 365-86.

${ }^{53}$ Donald Dickson, Thomas and Rebecca Vaughan's Aqua Vitæ: Non Vitis (Tempe: Arizona Center for Medieval and Renaissance Studies, 2001).

${ }^{54}$ Susanna Åkerman, Queen Christina of Sweden and Her Circle: The Transformation of a SeventeenthCentury Philosophical Libertine (Leiden: Brill, 1991); Tara Nummedal, The Lion's Blood: Alchemy, Apocalypse, and Gender in Reformation Europe (Philadelphia: University of Pennsylvania Press, forthcoming). See also Nummedal, "Alchemical Reproduction and the Career of Anna Maria Zieglerin" in Ambix, Vol. 48 (2001): 56-68.
} 
discussed in Chapter 2; Stanton J. Linden uncovered similar interests in Mary Trye's 1675 work Medicatrix: or the woman-physician. ${ }^{55}$ Bayer herself has analyzed the manuscript associated with Margaret Clifford, countess of Cumberland, the subject of Chapter 5. ${ }^{56}$ Finally, Jayne Archer's doctoral thesis and published works examine a number of early modern English women chymists. ${ }^{57}$ These and other texts informed and inspired the work undertaken in this thesis.

Chapter 1 focuses on Queen Elizabeth I, whose chymical interests and associations, I argue, shaped her self-fashioning. After examining her numerous interactions with chymists, I turn to the queen's iconographic appropriation of chymical imagery. Representations of Elizabeth as a goddess-like figure distanced her from ordinary Englishwomen while empowering them, recalling as she did chymistry's affiliations with both the natural world and domestic sphere. She thus enabled her female subjects to explore chymical knowledge without retribution or conflict.

In subsequent chapters, I focus on chymistry's place in the lives of individual women. Chapter 2 deals with Lady Grace Mildmay's charitable medical practice, which, motivated by faith and eschatological concerns, utilized chymical knowledge and techniques on a large, systematic scale. Lady Mildmay left to her daughter a substantial compilation of manuscripts that provide ample evidence of her chymical expertise. Unusually, she combined Galenic and Paracelsian medical techniques that are often viewed as contradictory. Her emphasis on effective treatment led her to engage with a chymical world that cohered with her religious convictions.

\footnotetext{
${ }^{55}$ Linda Pollock, With Faith and Physic: The Diary of a Tudor Gentlewoman: Lady Grace Mildmay, $1552-$ 1620 (London: Collins \& Brown, 1993); Stanton J. Linden, "Mrs Mary Trye, Medicatrix: Chemistry and Controversy in Restoration England" in Women's Writing, Vol. 1, No. 3 (1994): 341-53.

${ }^{56}$ Penny Bayer, "Lady Margaret Clifford's Alchemical Receipt Book and the John Dee Circle" in Ambix, Vol. 52, No. 3 (2005): 271-84.

${ }^{57}$ Archer, "Women and Alchemy." See also "'Rudenesse itselfe she doth refine': Queen Elizabeth I as Lady Alchymia" in Annaliese Connolly and Lisa Hopkins, eds., Goddesses and Queens: The Iconography of Elizabeth I (Manchester: Manchester University Press, 2008): 45-66; "Women and Chymistry in Early Modern England: The Manuscript Receipt Book (c. 1616) of Sarah Wigges" in Kathleen P. Long, ed., Gender and Scientific Discourse in Early Modern Culture (Aldershot: Ashgate, forthcoming 2010).
} 
In Chapter 3 I turn to Mary Sidney Herbert, countess of Pembroke, addressing the relationship between patronage, literary creation and her reputed practice of chymistry, itself a creative, transformative act. Renowned for editing and completing her late brother Philip's Arcadia and translation of the Psalms, Lady Pembroke transformed her residence at Wilton House into a haven for poets, scholars and chymists. There she presided as muse, echoing Lady Alchymia. Indeed, perhaps inspired by her mother's love of the subject, she counted chymistry among her many interests, pursuing the philosopher's stone in her own laboratory. The importance of community and connections to her chymical pursuits will recur in Chapters 4 and 5.

Lady Margaret Hoby, the subject of Chapter 4, reinforces the relationship between chymical activities and religious convictions. Her spiritual diary, the earliest extant autobiographical journal written by an Englishwoman, testifies to her strong predilection for iatrochemistry. Lady Margaret consulted herbals and catered to the medical needs of her household and North Yorkshire community, where as Protestants she and her husband were spiritually isolated. By closely examining her diary and chymical associations, this chapter sheds new light on her day-to-day activities.

In Chapter 5, I look at Margaret Clifford, countess of Cumberland. A patron of literature, voyages, mining and metallurgy, Lady Margaret took great pleasure in chymistry, which she, too, utilized for healing purposes. However, she also familiarized herself with the art's more esoteric aspects. Familial connections and friendships opened access to knowledge that would otherwise have been unavailable to her, as the so-called "Margaret Manuscript" and letters from Lord Willoughby to the countess indicate. Social connections between Herbert, Hoby and Clifford underscore the importance of community in early modern chymical practice.

I hark back to Elizabeth's influence in the conclusion by observing the archetypal roles that these gentlewomen fulfilled. Just as the queen's iconography embraced traditional imagery while empowering female subjects, so too did these women reflect the 
historical significance of their gender in alchemy. They acted as intermediaries between alchemists whose work served lofty chrysopoetic goals and the more pragmatic stance of the early scientists who followed. Finally, I turn to the continued increase in female practitioners during the seventeenth century as a product of Queen Elizabeth's legacy.

This thesis contributes to the limited historiography on female chymical practice in Elizabethan England, highlighting societal changes that enabled women to re-enter a chymical world dominated for centuries by men. I aim to respond to several questions: What enabled gentlewomen to begin pursuing chymistry during Elizabeth's reign? In what ways and to what extent did they engage with the chymical world? How did they reconcile these activities with their spiritual beliefs and assumptions about female virtue? By providing context for and detailed analysis of my subjects, this thesis will illuminate their motivations, relationships and legacies. 


\section{Chapter 1}

\section{Gnosis and Praxis: Queen Elizabeth I and Chymistry at Her Court}

Although Queen Elizabeth I (1533-1603) gained renown for her wisdom and intellect, few historians have acknowledged the importance of chymistry during her reign. Her belief in transmutation prompted the monarch to construct still-houses, patronize chymists and favor those who shared her fascination with chymistry. As we will see, many in the Elizabethan court pursued the philosopher's stone, and chymical imagery gained a wide audience. After examining the crucial role of gender to a ruling female monarch, this chapter explores the queen's chymical patronage throughout her reign and the incorporation of chymical symbolism in her iconography.

When Elizabeth acceded to the English throne on 17 November 1558 in the wake of her half-sister's demise, the Protestant exile John Knox had only recently published what would become his most famous tract. The First Blast of the Trumpet Against the Monstrous Regiment of Women railed against the Marian regime, attacking not the religious or political views that prompted him to flee to Switzerland, but the gender of the monarch upholding them. "To promote a woman to beare rule, superioritie, dominion or empire above any realme, nation, or citie," he claimed, "is repugnant to nature". Though Elizabeth's pre-Protestant views more closely aligned with Knox's own radical Presbyterianism — the crucifix remained for her a moving symbol rather than popish idolatry — she too would reign in defiance of the perceived natural order and, indeed, divine wisdom. $^{2}$ In his 1559 response to Knox, John Aylmer unwisely defended the new queen by introducing the experienced, competent men in her government as mediators

\footnotetext{
${ }^{1}$ Jane E.A. Dawson, "John Knox (c. 1514-1572)," ODNB, Oxford University Press, 2004; online edn., May 2008 [http://www.oxforddnb.com/view/article/15781, accessed 27 August 2010]; John Knox, The first blast of the trumpet against the monstrous regiment of women (1558), sig. B1r.

${ }^{2}$ Patrick Collinson, "Elizabeth I (1553-1603)," ODNB, online edn. [accessed 21 June 2010].
} 
between Elizabeth and the power she supposedly wielded, and subsequently waited decades to see his ambitions fulfilled. ${ }^{3}$ Accession Day marked her first attempt at reconciling these commonly held objections to a female ruling monarch. She did so through the manufacture of words and images that would persist long after the iconic Virgin Queen had succumbed to old age.

This thesis concerns itself with the myths surrounding Elizabeth. These representations, whether the products of self-fashioning, courtly propaganda or requests for patronage, reflected varying degrees of truth. Though Elizabeth and her privy council had a vested interest in manipulating her public persona, to assume that they "formed a monolithic entity that manufactured her image" would be a mistake. ${ }^{4}$ Motivations at court were no more unified than those of the Elizabethan populace. ${ }^{5}$ The queen knew that, in a sense, she created herself through the language she presented to her people. Elizabeth certainly had some control over her depiction. She could promote preferred representations while critiquing or even censoring those that did not align with her values. However, the words and images that contributed to the so-called "cult of Elizabeth" could just as easily be exploited by others in support of their own agendas. ${ }^{6}$ After all, the queen by definition ruled in relation to her subjects; this connection naturally shaped her representations, as pageantry, visual art, poetry and dedications indicate. Robert Dudley's elaborate 1575 Kenilworth entertainments, for instance, subtly pointed to his aspirations in the Netherlands with Arthurian allegories. ${ }^{7}$ Edmund Spenser explored similar themes in The Faerie Queene, which, though ostensibly written in praise of the queen, contained as

\footnotetext{
${ }^{3}$ See John Aylmer, An harborovve for faithful and trewe subjectes (Strasbourg/London, 1559); and Brett Usher, "John Aylmer (1520/1-1594)," ODNB, online edn. [http://www.oxforddnb.com/view/article/935, accessed 20 September 2010]; A.N. McLaren, Political Culture in the Reign of Elizabeth I: Queen and Commonwealth, 1558-1585 (Cambridge: Cambridge University Press, 1999): 59-69.

${ }^{4}$ Susan Frye, Elizabeth I: The Competition for Representation (Oxford: Oxford University Press, 1993 ): 8.

${ }^{5}$ Christopher Haigh, ed., The English Reformation Revised (Cambridge: Cambridge University Press, 1987): 7.

${ }^{6}$ See analysis by E.C. Wilson, Frances Yates and Roy Strong (and myriad responses to these three), as well as contemporary writings on Elizabeth by John Foxe, Raphael Holinshed and William Camden.

${ }^{7}$ See Frye, Elizabeth, Ch. 2. On gender mutability in Arthurian legends, see Heidi Breuer, Crafting the Witch: Gendering Magic in Medieval and Early Modern England (New York: Routledge, 2009), Ch. 2.
} 
much criticism as commendation. ${ }^{8}$ Such imagery could be harnessed for practical purposes, as when John Dee justified England's expansion under Elizabeth through King Arthur's legacy. ${ }^{9}$

Representations of Elizabeth reconciled her subordinate role as a woman with the seemingly contradictory power she wielded as ruling monarch. The queen presented herself as autonomous and independent, recognizing that, as a woman, she required a signifier that supported rulership over even her most powerful subjects without denying her gender. Divergent definitions of virtue applied to men and women, the latter taking the necessarily passive form of chastity. Three weeks after her coronation, with her first Parliamentary speech, Elizabeth presented herself as an eternal virgin, married only to her country. ${ }^{10}$ She had effectively taken ownership of her body, a role at once active and virtuous, and supplanted the imagery of the Virgin Mary that her regime had rendered sacrilegious. That she would not be publicly celebrated as the Virgin Queen until 1578 testifies to the vital role others — who had previously encouraged her marital prospects — played in cultivating this reputation. ${ }^{11}$ With external support, Elizabeth thus established herself as an "Earthlye Goddesse", as John Lyly wrote in $1580 .^{12}$ In doing so, she distinguished herself from ordinary women with a parallel to chaste deities such as Diana, Astraea, Sapientia and Alchymia. ${ }^{13}$ The opening woodcut in John Case's 1588 work

\footnotetext{
${ }^{8}$ See Frye, Elizabeth, Ch. 3; Andrew Hadfield, “Duessa's Trial and Elizabeth's Error: Judging Elizabeth in Spenser's Faerie Queene" in The Myth of Elizabeth, eds. Susan Doran and Thomas S. Freeman (Houndmills: Palgrave Macmillan, 2003): 56-76.

${ }^{9}$ See Strong, Gloriana: The Portraits of Queen Elizabeth I (London: Thames \& Hudson, 1987): 90-3; and Glyn Parry, The Arch-Conjuror of England: John Dee and Magic at the Courts of Renaissance Europe (New Haven: Yale University Press, forthcoming 2010), Ch. 9.

${ }^{10}$ Collinson, "Elizabeth I," ODNB.

${ }^{11}$ See Patrick Collinson, "Pulling the Strings: Religion and Politics in the Progress of 1578" in The Progresses, Pageants, and Entertainments of Queen Elizabeth I, Jayne Elisabeth Archer, Elizabeth Goldring and Sarah Knight, eds. (Oxford: Oxford University Press, 2007): 121-41, esp. 138.

${ }^{12}$ John Lyly, Euphues and his England (London, 1581 ed.), p. 120r.

${ }^{13}$ On Diana or Cynthia, see, for instance, Philippa Berry, Of Chastity and Power: Elizabethan Literature and the Unmarried Queen (London: Routledge, 1989): 86-7, 123-6, 139-43, 164-5; Susan Doran, "Virginity, Divinity and Power: The Portraits of Elizabeth I" in The Myth of Elizabeth, eds. Susan Doran \& Thomas S. Freeman (Houndmills: Palgrave Macmillan, 2003): esp. 189-90; on Astraea, see Frances Yates, "Queen Elizabeth I as Astraea" in Astraea: The Imperial Theme in the Sixteenth Century (London: Pimlico, 1993): 29-87; Strong, Gloriana, 133; on Alchymia/Sapientia, see Jayne Elisabeth Archer, " Rudenesse it selfe she
} 
Sphaera Civitatis, for example, depicts Elizabeth as presiding over the celestial spheres, while the verses that follow emphasize her connection to Astraea. John Gerard, too, visually represented the queen as Flora reigning over the natural world in his 1597 Herball.

Queen Elizabeth drew on a rich history of sacred authority adapted by secular rulers. This narrative began with the claims of Roman emperors to divinity and extended to the "Royal Touch" English monarchs had used to heal the sick since the time of Edward the Confessor, echoing Christ. ${ }^{14}$ It also manifested in medieval political theories on the two divided, linked bodies that constituted a ruling monarch: "the King has in him two Bodies, viz. a Body natural, and a Body politic", the former subject to the same physical shortcomings as the bodies of his subjects, while the ageless latter, which "cannot be seen or handled", transcended such flaws. ${ }^{15}$ Cited in a 1561 court case to reinforce the validity of land leases King Edward VI had made before legally coming of age, the notion of the king's two bodies could be applied to ruling queens as well, though in an apparently paradoxical manner. ${ }^{16}$ A ruling woman superimposed her powerless female body with the political realm heretofore inhabited only by powerful males. Elizabeth evoked these dual aspects in her famous speech at Tilbury in 1588, while exhibiting the decidedly masculine virtue of courage: "I know I have the body but of a weak and feeble woman, but I have the heart and stomach of a king and of a king of England too". ${ }^{17}$ She located herself in a long line of English rulers while reminding her troops that she differed from her predecessors in one significant way - a fact that they surely had not neglected any more than their queen could.

doth refine': Queen Elizabeth I as Lady Alchymia" in Goddesses and Queens: The Iconography of Elizabeth I, eds. Annaliese Connoly and Lisa Hopkins (Manchester: Manchester University Press, 2007): 45-66.

${ }^{14}$ Helen Hackett, Virgin Mother, Maiden Queen: Elizabeth I and the Cult of the Virgin Mary (Houndmills: Macmillan, 1995): 18.

${ }^{15}$ Edmund Plowden, The Commentaries, or Reports, Part I (London: S. Brooke, Paternoster-Row, 1816):

212. Originally published in French in 1571 and 1578.

${ }^{16}$ See Ernst H. Kantorowicz, The King's Two Bodies: A Study in Mediaeval Political Theology (Princeton: Princeton University Press, 1957): esp. 405; Marie Axton, The Queen's Two Bodies (London: Royal Historical Society, 1977).

${ }^{17}$ Collinson, "Elizabeth I," ODNB. 
Elizabeth's political body afforded her a remarkable degree of gender fluidity that recalled the transformation inherent to chymical allegories and, in particular, the hermaphrodite. Susan Frye has noted that the monarch's two opposing, complementary bodies allowed her to assume "the assigned gender roles of women, men, or both, or someone in between, as the occasion demanded". ${ }^{18}$ In chymistry, the hermaphrodite necessarily preceded creation of the philosopher's stone, integrating the male and female principles, which took many forms: sulphur and mercury, king and queen, Sol and Luna. ${ }^{19}$ The chymical wedding's resulting unification is portrayed as both a monster (unnatural) and a god (supernatural), categories that resonated with Elizabeth herself, from Knox's assessment of female rulers as "repugnant to Nature" to her deific presentation effectively situated beyond nature. Significantly, the hermaphrodite could also represent Jesus Christ, playing upon obvious parallels between transmutation and transubstantiation. ${ }^{20}$ Kathleen Long has stated that hermaphroditic metaphors implied "attraction towards sexual ambiguity as well as fear of transgression of sexual roles" based on biological sex and gender stereotypes. ${ }^{21}$ By embracing parallels to a symbol that represented both genders and neither, Elizabeth transcended the limitations of her natural body. In the following paragraphs, I will explore more tangible evidence of her interest in chymistry.

Until 1689 English law considered alchemy, "the Craft of Multiplication”, a felony punishable by death and forfeiture of goods. ${ }^{22}$ Would-be practitioners were therefore required to obtain special royal dispensation. Edward III, Henry VI and Edward IV all participated in this tradition, as did Elizabeth Tudor's father. ${ }^{23}$ In December 1547 Henry

\footnotetext{
${ }^{18}$ Frye, Elizabeth, 13. Includes additional examples of the queen's elasticity when discussing her own gender.

${ }^{19}$ Lyndy Abraham, A Dictionary of Alchemical Imagery (Cambridge: Cambridge University Press, 1998): 98-9.

${ }^{20}$ On this topic see Leah DeVun, "The Jesus Hermaphrodite: Science and Sex Difference in Premodern Europe" in Journal of the History of Ideas, Vol. 69, No. 2 (2008): 193-218.

${ }^{21}$ Kathleen P. Long, Hermaphrodites in Renaissance Europe (Aldershot: Ashgate, 2006): 5.

${ }^{22}$ F. Sherwood Taylor, The Alchemists (London: Scientific Book Club, ca. 1950): 124.

${ }^{23}$ Edward III's 1329 patent preceded the outlawing of alchemy in 1403/4. Archer, "Lady Alchymia," p. 53.
} 
VIII employed Richard Eden as a distiller of waters in the royal household. This distinguished position carried with it a respectable annual salary of $£ 40 .^{24}$ Unfortunately, the king, whose numerous health problems likely inspired his interest in chymical cures, died early the following year, taking with him Eden's good fortune; the post went to another man. However, the late monarch's second daughter was already nurturing a nascent interest in chymistry through her elite education, maintaining a tradition that associated royal status with chymical knowledge and the accompanying access to - and control over — powerful natural forces.

A contemporary biographer, William Camden, described Elizabeth as "indefatigably given to the study of learning", a characteristic in which she took great pride. ${ }^{25}$ In 1585 she informed Parliament that "I am supposed to have many studies, but most philosophical", and many knew of her partiality for natural philosophy. ${ }^{26}$ Among the scholars who had educated the learned young princess were John Cheke and Thomas Smith, humanists who obsessively pursued the philosopher's stone; their pupils included Eden and William Cecil, who shared Elizabeth's interest in chymistry and would become her chief advisor. ${ }^{27}$ Cheke and Smith's guidance had a lasting impact on Elizabeth's belief in chymical efficacy. This educational background helps to explain the queen's establishment of "manifold... still-houses" during her reign. ${ }^{28}$ Like her father, Elizabeth intended to continue patronizing chymists. The queen's chymical endeavors indicate that firsthand experience with the Great Work motivated her decision to patronize — or

\footnotetext{
${ }^{24}$ David Gwyn, "Richard Eden, Cosmographer and Alchemist" in The Sixteenth Century Journal, Vol. 15, No. 1 (1984): 17; and Andrew Hadfield, "Richard Eden (c. 1520-1576)," ODNB, online edn. [http://www.oxforddnb.com/view/article/8454, accessed 1 September 2010].

${ }^{25}$ Quoted in John Nichols, The Progresses and Public Processions of Queen Elizabeth, Vol. I (London: 1823), p. ix.

${ }^{26}$ J.E. Neale, Elizabeth I and Her Parliaments: 1584-1601 (London: St. Martin's Press, 1958): 100.

${ }^{27}$ Mary Dewar, Sir Thomas Smith: A Tudor Intellectual in Office (London: Athlone Press, 1964): 15; Brian Vickers, Occult \& Scientific Mentalities in the Renaissance (Cambridge: Cambridge University Press, 1984): 80-1; Lansdowne Vol/101 f.17 ("Richard Eden," 1 August 1562); TNA: SP 70/146 f.56 (Thomas Smith to Richard Eden, 9 March 1572).

${ }^{28}$ Ralph Rabbards, ed., George Ripley's The compound of alchymy (London: Thomas Orwin, 1591), dedicatory epistle. On the distiller she employed at her still-houses in Hampton Court from February of 1561 , see below.
} 
punish — those who possessed knowledge of the subject. The following accounts should be viewed as exemplary rather than exhaustive. ${ }^{29}$

The Elizabethan State Papers provide ample evidence of the queen's appropriately mercurial nature where chymists were concerned. Jayne Archer has identified "John Dethicke" as early evidence of Elizabeth's chymical patronage. ${ }^{30}$ This case also marks the first time her supporters utilized chymistry to advance her position. Dethicke was involved in Henry Sutton Dudley’s anti-Spanish plot in 1556, while Mary still reigned, and it appears that his contribution to the cause consisted primarily of knowing the right people; he recruited William Hinnes or Hunnis "as having skill in alchymy, to make experiments on a foreign coin called ealdergylders, to convert them into gold". 31 Depositions related to this case situate chymical practice in the wider political context while indicating the air of restless dissent that prevailed when Elizabeth took the throne. The Marian regime's alliance with Catholic Spain and the Holy See and the ensuing revival of heresy laws prompted outrage among persecuted Protestants. With their plans to transmute Dutch currency, Dethicke and his co-conspirators hoped to fund a rebellion that would establish Elizabeth's right to the throne. ${ }^{32}$

Many sought the queen's consideration, but few were rewarded with chymical appointments. William Hogan may have been the first. ${ }^{33}$ On 18 February 1561 he received a lifelong grant to perform distillations at Hampton Court involving "all manner of herbs, waters and other necessaries". ${ }^{34}$ As with Richard Eden's position, Hogan's work yielded an annuity of $£ 40$. A commission dated several months later elaborates on the

\footnotetext{
${ }^{29}$ See, for instance, TNA: SP 12/71 ff.156, 158.

${ }^{30}$ Archer, "Lady Alchymia," p. 53.

${ }^{31}$ Quoted from the calendar, as manuscript scan unavailable via SP Online. TNA: SP, Mary Vol. VII, 46, p. 77. See also SP 11/7 f.87; and J. Andreas Löwe, "Henry Sutton [Dudley] (d. 1564?)", ODNB, online edn. [http://www.oxforddnb.com/view/article/8151, accessed 16 September 2010].

32 TNA: SP, Mary Vol. VIII, 64, 83.

${ }^{33}$ I am grateful to Glyn Parry for alerting me to the Hogans and sharing manuscripts related to their chymical activities.

${ }^{34}$ TNA: C66/973, 182-3.
} 
nature of the work, indicating a close connection with Elizabeth herself. Hogan was expected

to take up throughout England for the queen's use all manner of roses, herbs and flowers with all kinds of glasses suitable for the keeping of sweet waters, also all kinds of trees...for the stilling of the said waters...He has been appointed to have the keeping of the two little gardens called the New Gardens... with the stilling houses incident to the same, and the charge of planting there all kinds of wholesome herbs and trees together with the stilling of sweet waters for the queen's use. ${ }^{35}$

Here we find chymical techniques harnessed for decidedly domestic purposes, Hogan's position analogous to that of any craftsman serving the queen on an ongoing basis. Several years later he was associated with a plot to discredit Robert Dudley, earl of Leicester and the queen's favorite. While staying with Hogan in Hampton Court, his brother-in-law John Appleyard made the acquaintance of an unknown man who offered him the tidy sum of $£ 4,000$ to implicate Leicester in the 1560 death of his wife, Appleyard's half-sister, Amy Robsart. ${ }^{36}$ It had officially been ruled an accident, but rumors about Dudley’s involvement persisted, perpetuated by those concerned he and Elizabeth might marry. Although Appleyard later recanted, records indicate that Cecil questioned Hogan about the matter. ${ }^{37}$ Curiously, it did not affect his standing with the queen, as he retained his position for two more decades. On 22 June 1588 the queen's letters patent extended this role to his son, also named William, through lives in survivorship, though the handover did not occur until the reign of James $\mathrm{I}^{38}$

Others sought employment in the royal household. Thomas Charnock dreamt of following in his uncle and namesake's footsteps by becoming “the Queenes philosopher". The elder Thomas Charnock had served as Henry VII's confessor. More significantly, he

\footnotetext{
${ }^{35}$ TNA: C66/970, 123.

${ }^{36}$ Stanley T. Bindoff, The House of Commons: 1509-1558; Members D-M (London: Secker \& Warburg Ltd., 1982): 371 ("William Hogan").

37 TNA: CMS, Vol. 1, S.R. Scargill-Bird, ed. (London: 1883), 351.

${ }^{38}$ TNA: 66/1304, TNA: C 54/1763.
} 
claimed to have obtained the philosopher's stone from a fellow Black Friar in $1515 .^{39}$

His nephew's 1565 "Booke Dedicated vnto the Queenes maiestie" promised Elizabeth the health and riches typically associated with the stone in exchange for a fourteen-year subsidy. ${ }^{40}$ Like Charnock's other extant writings, this petition offers a vivid glimpse of its unlearned author's life, beliefs and chymical experiences. He took an apocalyptic view of the Great Work, holding that successful transmutation was a harbinger of the Last Judgment, so it was perhaps fortunate that Elizabeth and her advisors declined to accept his offer. The queen may not even have seen the gold-tooled, leather-bound manuscript, which remains among William Cecil's papers. ${ }^{41}$ Charnock's digressive dedication fell flat in the wake of a more impressive one from Dutch chymist Cornelius de Lannoy.

After first contacting William Cecil, in February 1565 de Lannoy wrote to the queen, suggesting that knowledge of her chymical interests had traveled beyond England's borders. He offered to produce a staggering fifty thousand marks worth of pure gold and precious stones on an annual basis. ${ }^{42}$ Elizabeth had inherited a crown laden with debt. Spain's interference with Dutch trade and the 1563 plague, which killed as much as a quarter of London's population and hit the rich central parishes particularly hard, further weakened England's economy. ${ }^{43}$ Keenly aware of the treasury's limitations, Elizabeth and Cecil believed that the possible benefits of this alliance justified the comparatively minor up-front expenses. They granted the chymist use of Somerset House and the costly equipment and materials he would require. In addition, de Lannoy received monthly

\footnotetext{
${ }^{39}$ Allan Pritchard, “Thomas Charnock's Book Dedicated to Queen Elizabeth" in Ambix, Vol. 26, No. 1 (1979): 58.

${ }^{40}$ Robert M. Schuler, “Thomas Charnock (1524x6-1581)," ODNB, online edn.

[http://www.oxforddnb.com/view/article/5173, 3 September 2010].

${ }^{41}$ Pritchard, "Thomas Charnock's Book," 56-7; Lansdowne MS. 703.

42 TNA: SP $12 / 36$ ff.24-5.

${ }^{43}$ See Norman Jones, The Birth of the Elizabethan Age: England in the 1560s (Oxford: Blackwell, 1995); P. Griffiths, J. Landers, M. Pelling and R. Tyson, "Population and disease, estrangement and belonging, 15401700" in The Cambridge Urban History of Britain, Vol. II, ed. Peter Clark (Cambridge: Cambridge University Press, 2000): 204; Paul Slack, The Impact of Plague in Tudor and Stuart England (Oxford: Oxford University Press, 1985): 115.
} 
household living expenses and an annual pension of $£ 120$ with quarterly advance payments. $^{44}$

Only a few months had passed before de Lannoy began to behave suspiciously. Armagil Waad, through whom Cecil supervised the chymist's activities, wrote in August of de Lannoy's dissatisfaction with English glass-making skills, an effective stalling tactic. ${ }^{45}$ His "frequent counsel" with Princess Cecilia of Sweden gave Cecil and the queen another reason to worry. ${ }^{46}$ In January of 1566 he pledged to lend her $£ 10,000$ to repay debts, hinting at Cecilia's extravagant lifestyle during her visit to England. When confronted by Waad, de Lannoy promised to cease communications with the princess and members of her household — and promptly sent a volley of letters to the Swedes, unaware that they were being intercepted. As de Lannoy's duplicity became evident, with plans to flee uncovered by Cecil's spies, the likelihood of successful transmutation for the crown began to evaporate. ${ }^{47}$ Significantly, Elizabeth, Cecil and Waad doubted not his ability to produce the philosopher's stone, but rather the foreign chymist's loyalty to England.

Waad believed that de Lannoy possessed both the "Medicine or Elixir" and an accurate text on transmutation, but intended to keep them for himself. ${ }^{48}$ His correspondence recorded the queen's visit de Lannoy's laboratory, where she obtained a copy of the chymical work. ${ }^{49}$ That she wanted to see firsthand the progress he had made reveals the importance of the matter to her and the confidence she had in her own abilities to recognize genuine chymical knowledge. Similarly, that he neglected to provide background information or explain how to proceed indicates his awareness of Elizabeth's own chymical expertise. However, a subsequent boast to Waad that he had omitted crucial information from the manuscript suggests that he did not think very highly of her

\footnotetext{
${ }^{44}$ TNA: SP $12 / 37$ f. 9

${ }^{45}$ TNA: SP $12 / 37$ f.5.

46 1073, $1081 C M S$, ed. Scargill-Bird, 325, 327.

47 1078, CMS, ed. Scargill-Bird, 326.

48 TNA: SP 12/39 f.119.

${ }^{49}$ Ibid.
} 
abilities. ${ }^{50}$ Personally affronted, and believing Waad's report that de Lannoy was keeping the transmuted gold for himself, Elizabeth placed him under house arrest. Even at this late juncture the queen, Cecil and the earl of Leicester, who had taken an interest in the matter, still hoped that the chymist would deliver on his promises. They relocated him with his laboratory to the Tower in mid-1566. He reiterated his good intentions but his chymical operations proved unsuccessful. De Lannoy's betrayal confined him to a cell until at least $1571 .^{51}$ Chastened, Elizabeth approached subsequent chymical endeavors with caution. In 1568 Cecil attempted to secure her support for an Italian chymist who had petitioned him, but she would "in no wise hear of any such offers, which she thinketh are but chargeable without Fruit". ${ }^{2}$

Queen Elizabeth and William Cecil were not alone in their preoccupation with transmutation. In the late 1560 s and 1570 s, the Elizabethan court's obsession with chymistry reached its zenith. The incorporation of organizations like the Society of Mines Royal and the Company of Mineral and Battery Works and courtly support for mining and metallurgical ventures, including William Medley's "Society for the New Art" and Martin Frobisher's exploratory voyages, indicate widespread acceptance of chymical techniques. Medley's plans to produce copper, which I will discuss at length in Chapter 3, attracted the attention of Cecil, Leicester, explorer Sir Humphrey Gilbert, the queen's former tutor Sir Thomas Smith, and Henry and Mary Sidney, among others. Leicester also patronized Frobisher and held shares in the Mines Royal.

During the 1570 s we find a rise in apocalyptic prophecies relating to both the queen and chymistry. Christianity's somewhat ambiguous position on the End Times produced two opposing perspectives. The orthodox notion of a calamitous reign of evil contrasted with a "Messianic Age of Gold" — interpreted spiritually or in more earthly terms —

\footnotetext{
${ }^{50}$ TNA: SP $12 / 40$ f.76.

${ }^{51}$ See the 1571 petition from Barbara de Lannoy, wife of Cornelius, to Leicester: Longleat House, The Dudley Papers, DUI/f.209r.

${ }^{52}$ Anon, Cabala, Sive Scrinia Sacra: Mysteries of State and Government in Letters (London, 1691): 139 (William Cecil to Sir Henry Norris, 1568).
} 
ushered in by direct divine intervention in human affairs and the destruction of the Antichrist. ${ }^{53}$ Controversial medieval prophet Joachim of Fiore embraced this more optimistic stance with his Trinitarian vision of history, framing the golden age as the culmination of a long, arduous pilgrimage. He helped revive the idea that a human savior, a "Last World Emperor", would partially vanquish evil before ultimately surrendering while God interceded.

Joachim's theories influenced prominent chymists and physicians like Arnold de Villanova, Johannes of Rupescissa and Paracelsus, himself a prophet. Through their writings the End Times narrative soon incorporated medical events such as the spread of syphilis. $^{54}$ Disease, famine and religious strife were seen as symptoms of the decay wrought by human sin, as Grace Mildmay's spiritual writings will illustrate in the next chapter. Post-Reformation millenarianism thus grew from medieval roots. This perspective provided a powerful stimulus to practice chymistry, which, like the notion of the Last World Emperor, embodied idealism, reform and renewal, rejuvenating the decaying world and restoring the bountiful garden lost when Eve fell. ${ }^{55}$ It constituted the missing link between eternal knowledge and the earthly world's dissolution and putrefaction. The philosopher's stone in particular became closely affiliated with the Last World Emperor, who by harnessing its powers would inaugurate the golden age.

In the 1570s, English Protestants capitalized on the popularity of prophecies about the Last World Emperor by applying them to Elizabeth. Contrary to Jennifer Forster's claim that there were no corresponding theories of messianic rule for women, these writers portrayed the queen as the Last World Empress, their expectations of improvement derived from her learned reputation — particularly her familiarity with chymistry — and godly

\footnotetext{
${ }^{53}$ See Marjorie Reeves, The Influence of Prophecy in the Later Middle Ages: A Study in Joachimism (Oxford: Clarendon Press, 1969): esp. 295-319.

${ }^{54}$ Charles Webster, Paracelsus: Medicine, Magic and Mission at the End of Time (New Haven: Yale University Press, 2008): 203, 219.

${ }^{55}$ On the kinship of chymistry, millenarianism and cosmopolitanism, see Margaret C. Jacobs, Strangers Nowhere in the World: The Rise of Cosmopolitanism in Early Modern Europe (Philadelphia: University of Pennsylvania Press, 2006): 64-5.
} 
image. ${ }^{56}$ James Sandford, a translator who had previously tackled a satirical work by occultist Heinrich Cornelius Agrippa, exemplified this viewpoint with his 1576 publication Houres of Recreation. He had dedicated an earlier edition to the earl of Leicester, aligning himself with those who advocated a dramatic shift in foreign policy to an anti-Habsburg stance. The appropriation of the Last World (or Roman) Emperor of late antiquity, which strongly influenced Habsburg imperial mythology, confirmed his affiliations. ${ }^{57}$ After praising the queen as "skilful...in the heauenlye Philosophy" and "endewed with Salomons wisedome", Sandford asserted that "there must needes be some diuiner thing in hir Maiestie, than in the Kings and Queens of other countries". ${ }^{58}$ Wisdom and earthly divinity enabled her to lead the fortunate into the golden age forecast so long ago. This expectation circulated in prophetic manuscripts claiming that "Elizabeth now Queene of England is ordained of God to be Queene of Jerusalem". 59

Though he took a less distinctively Protestant stance, John Dee also held that the queen would restore world peace and plenty. His imperial writings cited the Arthurian Empire as justification for England's expansion under Elizabeth; he had undoubtedly learned that Habsburg court culture celebrated Arthur as the model for their own Endzeitkaiser, or Last World Emperor, during his earlier studies at Louvain. ${ }^{60}$ Dee's 1577 work General and rare memorials pertayning to the perfect arte of nauigation promised Elizabeth the philosopher's stone with which she would herald the abundant Age of Gold. She need only employ a quartet of "Christian Philosophers, Skilfull, or to become Skilfull” in "the Ancient and Secret Philosophie". 61 Dee thus linked the English Empire's

\footnotetext{
${ }^{56}$ Jennifer Forster, “Anticipating the Apocalypse: An Elizabethan Prophecy" in The Historian, Vol. 63, No. 3 (2001): 614-7.

${ }^{57}$ See Marie Tanner, The Last Descendent of Aeneas: The Hapsburgs and the Mythic Image of the Emperor (New Haven: Yale University Press, 1993): esp. 119-30; Paul J. Alexander, "The Medieval Legend of the Last Roman Emperor and its Messianic Origin" in Journal of the Warburg and Courtauld Institutes, Vol. 41 (1978): 1-15.

${ }^{58}$ James Sandford, trans., Houres of recreation, or afterdinners (London: Henry Binneman, 1576), dedicatory epistle.

${ }^{59}$ See Richard Bancroft, A sermon preached at Paules Crosse the 9. of Februarie (London, 1588), sig. B4v.

${ }^{60}$ Parry, Arch-Conjuror, Ch. 10.

${ }^{61} \mathrm{John}$ Dee, General and rare memorials pertayning to the perfect arte of nauigation (London, 1577), p. 62.
} 
expansion to production of the sacred stone, leading to rumors that the queen would soon acquire it. ${ }^{62}$ As these writings indicate, religious expectations about the End Times shaped public perceptions of chymistry.

Figure 1: Lady Alchymya

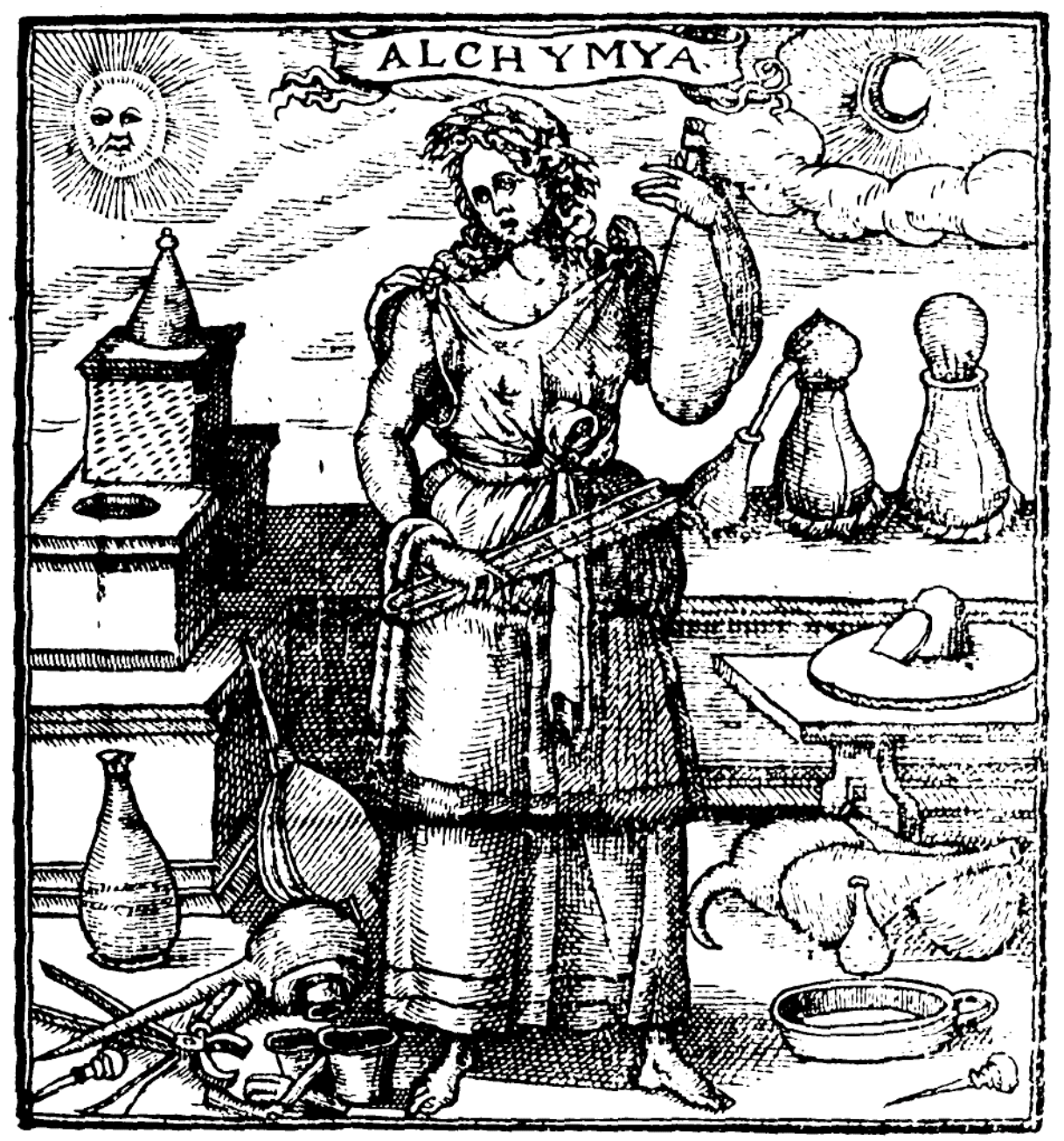

Source: George Baker, The newe Jewell of Health (1576), frontispiece.

Illustrations in works of natural philosophy provide further evidence of chymistry’s association with Elizabeth in the 1570s. George Baker's 1576 translation of The newe Jewell of Health featured on its title page the muse Alchymya, standing between Sol and

\footnotetext{
${ }^{62}$ Dee is credited with coining the term "British Empire." Parry, Arch-Conjuror, Ch. 10.
} 
Luna and surrounded by chymical apparatus (Figure 1). ${ }^{63}$ In July of the following year, Samuel Norton — clearly aware of the prophecies circulating about the queen — applied this imagery to Elizabeth with an allusion to his great-grandfather Thomas Norton's Ordinall of Alchemy:

speaking of the Stone to be revealed to the kings of the Land it shall be found he saith:

By the fortune + by the grace

Of a woman faire of face

And what know I, Oh Queene! whether it be yr. selfe or noe? ${ }^{64}$

As Alchymia, the queen represented both the philosopher's stone itself, which Norton evidently believed she would soon possess, and the means by which it could be attained as a patron (fortune) and muse (grace). These influenced the queen's portraiture and increased her association with the royal art.

Chymistry's widespread acceptance extended to a most unlikely location: King's Bench prison in London. Deborah Harkness recently illuminated the life of Clement Draper, a member of the middling class detained in the prison for debt to the crown. ${ }^{65}$ There he engaged in limited scientific practice for more than a decade, documenting print and manuscript recipes for iatrochemical, chrysopoetic and less easily identifiable aims. His imprisonment was the direct result of the interest he took in the natural world. After losing money on Frobisher's enterprise, Draper attempted to recoup his losses with another metallurgical venture. Together with Richard Leycolt and John Mansfield, in 1579 he leased the Alum Chine mines at Canford, Dorset, from James Blount, Lord Mountjoy. When Mountjoy died heavily indebted in 1581, Henry Hastings, the earl of Huntingdon, who years earlier had purchased the estate at Canford, asserted his rights to the mines. The ulterior motives of Draper's partners would be his downfall, as Leycolt, backed by the earl, encouraged unwise investments. When he failed to make an interest payment later that

\footnotetext{
${ }^{63}$ Conrad Gesner, The newe Jewell of Health, George Baker, trans. (London: Henrie Denham, 1576). This image was adapted from Leonhard Thurneisser's Quinta Essentia (Leipzig, 1570).

${ }^{64}$ Quoted in Charles Nicholl, The Chemical Theatre (London: Routledge \& Kegan Paul, 1980): 18.

${ }^{65}$ Harkness, The Jewel House, 181-210.
} 
year, Clement Draper found himself imprisoned. Despite exploring every available avenue, sending correspondence on the matter to his allies, adversaries and government officials alike, he would spend at least twelve years in the King's Bench.

Draper knew of the queen's taste for chymistry. Harkness's analysis focuses on the experimental notebooks and receipt books he recorded while behind bars, noting a petition sent to Elizabeth only in passing. ${ }^{66}$ That letter, dated 12 September 1592, deserves greater attention. The relatively unremarkable main body demonstrates the narrative of the unjustly imprisoned, pleading Draper's case. By contrast, the third page opens with hieroglyphs that refer to the Galenic humoral system, the philosopher's stone, and a trinitarian breakdown of matter as animal, vegetable and mineral. With leading questions about the nature of the philosopher's stone, Draper drew parallels between the stone, Jesus Christ and the godly queen to whom he wrote. The earthly and heavenly, bodily and spiritual, human and divine meet in his assessment of "the most gloriows Sincere pure Worde of god, wherof the sowle of Man doth spiritualy feed" as the mortal body thrives on bread. To the aging queen he emphasized the stone's regenerative properties, adopting an eschatological perspective that observes Revelations in Genesis: "By vertue of ye passion, deathe and Resurrection of our Tryumphant Redemer Christ Ihesus owr Lorde \& our godd, prepared for all ye belevinge Saynts, predestinatid therunto. Even from the first Creation of all thinges". Like Thomas Charnock and Cornelius de Lannoy, Clement Draper hoped to gain Elizabeth's favor through his knowledge of the philosopher's stone.

In October of the following year, Roloff Peterson, a merchant from Lübeck, wrote to the queen of his chymical inheritance. One of his lodgers, a Kentish chymist named Clement Oldfield, had revealed a great secret the night before passing away. The conveniently deceased, unverifiable source of chymical wisdom is a common trope in tales of the philosopher's stone. Charnock's book for the queen similarly described the sources

\footnotetext{
${ }^{66}$ TNA: SP 12/243 f.15.
} 
of his knowledge; one teacher died after making Charnock his heir, while the other became deranged and blind as a result of the Great Work. ${ }^{67}$ Oldfield had " $\mathrm{w}^{\text {th }}$ Longe Labores ande deepe serchinge, in the mysteres of natur" made a discovery so precious it was suitable for "none but highe and mighty princes". ${ }^{68}$ He shared the knowledge with Peterson:

he informed me lardgely, of the secrette of this arte $\mathrm{w}^{\text {ch }}$ consistethe in the knoweledge of the grene and reede Lion from whence a fyry nature is to be felt, $\mathrm{w}^{\text {ch }}$ the Philosophers do call primam materiam : man and woman :

Mercury and Sulphur...Ande is caulede by manny other names $\mathrm{w}^{\text {th }}$ out $\mathrm{w}^{\text {ch }}$ ther is nether begeninge no ${ }^{r}$ ende in Alchemy.

In gratitude for Peterson's kindness, he offered a trio of glass bodies containing alchemical preparations of Sol, Luna and Mercury, hoping his landlord of the previous six years would be able to profit from the concoctions. ${ }^{69}$ Oldfield bound Peterson by oath to present the matter first to Queen Elizabeth, stating that one skillful in the art should examine his creations. If she did not respond within six months, Peterson could freely contact others. An extant note of the contents of Peterson's letter to Elizabeth indicates that he kept his word. $^{70}$

This letter arrived at a time when tales of Edward Kelley's successful transmutations in Bohemia had reached the English court. Between 1588 and 1593 Elizabeth repeatedly sent representatives such as Edward Dyer, Thomas Webb and Lord Willoughby to Europe, hoping to convince Kelley to return to his native land. Though the Elizabethan treasury recovered somewhat in the decades following the de Lannoy debacle, the war with Spain had depleted English resources. Elizabeth and Cecil, now Lord Burghley, once more saw in transmutation a solution to these financial woes. The queen's prompt response to Peterson's offer indicates her interest in his chymical preparations. Unwilling to pass this opportunity by, she took precautions to avoid being duped. Her

\footnotetext{
${ }^{67}$ Pritchard, "Thomas Charnock's Book," 58.

68 TNA: SP 12/245 f.210.

${ }^{69}$ TNA: SP $12 / 247$ f.56.

70 TNA: SP 12/75 f.156. In the Calendar this document has mistakenly been dated 1570, and Roloff Peterson's given name written as "Jo:".
} 
reply specified that the glass bodies be delivered to her, along with any related books or papers on the subject. Elizabeth also inquired whether Oldfield had mentioned "any lacke or imp[er]fection in any of the said materialls", which she supposed to be "but $p[$ ar]ts and beginnings" of the Great Work. ${ }^{71}$ Her request for a "secreat Menstruum, containing diuers notable vertues", should it exist, also suggested familiarity with chymical texts. A subsequent declaration dictated a slight change of plans, with Oldfield's vessels being sealed and sent instead to the deputy of the Merchant Adventurers at Stade. ${ }^{72}$ There an expert would examine them. The queen agreed to pay Peterson $£ 500$ for the materials "if we shalbe pleased to detaine and kepe the thinges bequeathed to our own vse".

It seems that the expert thought little of Oldfield's creations, and on 4 October 1595 Cecil wrote to Robert Smith, who had been hired to find a buyer for the glasses, that "hir $\mathrm{Ma}^{\text {ty }}$ hath bene informed credibly, $\mathrm{y}^{\mathrm{t}}$ they are no valew, and therfor to sell them war to deceave $\mathrm{y}^{\mathrm{e}}$ buyars, $\mathrm{w}^{\mathrm{ch}}$ in no wise wer honorable to be done in hir $\mathrm{Ma}^{\text {ty }}$ s name". ${ }^{73}$ In the spring of 1595 Peterson had traveled to Stade demanding the money owed him — and refusing to accept the sealed glasses, the agreed-upon deadline having passed. Petitions and protests from the Merchant Adventurers resulted, and a 1597 letter from Peterson detailing his injuries indicates that a resolution still had not been reached two years later. ${ }^{74}$ In fact, he took his complaint to an external authority: Rudolf II, the Holy Roman Emperor. The outcome of the case is unclear, but it illustrates the ongoing belief at Elizabeth's court in the reality of transmutation. The queen, Cecil and those who assisted with the matter recognized the potential value of chymical equipment even as they acknowledged the risks involved with accepting Peterson's tale.

Elizabeth had a complex relationship with the chymists who sought her patronage. Comparing her behavior to that of the "chaste prostitute" Alchymia, whom Trithemius

\footnotetext{
${ }^{71}$ TNA: SP 12/247 f.116; note that "pts" may be "pcs", denoting "pieces".

72 TNA: SP 12/250 f.10.

${ }^{73}$ TNA: SP $12 / 254$ f. 7 .

${ }^{74}$ See TNA: SP 12/264 f.209; SP 12/251 f.95; and CMS MS 370, 177.
} 
claimed had many lovers but granted her favors to none, Jayne Archer has suggested that the queen approached these aspirants with a "technique of evasion" characterized by delaying tactics and intermediaries. ${ }^{75}$ While to some extent accurate, this perspective simplifies the multifaceted role and perception of chymistry at Elizabeth's court. In the case of de Lannoy the chymist, not the queen, introduced delays. Elizabeth understandably distanced herself from failures of any kind as anathema to her deific image, but we find a corresponding willingness to reward victory in the long-term employ of the Hogans and her repeated attempts to retrieve Edward Kelley from the Continent; she also favored known chymists in spite of their shortcomings, as we will see in Chapter 4 with John Thornborough. Direct communications or endorsement from the queen may have signaled a shift in the power balance that she could not risk. For instance, in 1587 Elizabeth's letter commanding Kelley to return to England was hidden within other correspondence lest it draw unwanted attention to the matter. ${ }^{76}$ An overt expression of interest on her part could indicate that she had more to gain than the lowly natural philosophers requiring her financial assistance. Those who mediated for her thus effected the necessary gap between monarch and subject, echoing the role of Elizabeth herself in the massive "Ditchley" portrait (ca. 1592), which portrays the queen as linking the divine and terrestrial spheres, simultaneously embodying herself, her country and her kingdom. ${ }^{77}$ In the highly symbolic world of Elizabethan visual art we find lasting evidence of her chymical associations.

Over the course of her reign, paintings of Elizabeth I underwent a striking transformation. Whereas the early works depicted her as an individual, portrayal of the queen as a symbol later dominated, a reflection of her association with chaste goddess figures. $^{78}$ This transcendence of ordinary humanity inspired visual artists who wished to

\footnotetext{
${ }^{75}$ Archer, "Lady Alchymia," 46.

${ }^{76}$ See BL MS Harley 6986, fo. 45r.

${ }^{77}$ Roy Strong, Gloriana: The Portraits of Queen Elizabeth I (New York: Thames \& Hudson, 1987), 136.

${ }^{78}$ Ibid., 9.
} 
make evocative statements with their work. Her cosmological powers thus empowered them. Little has been said about the chymical symbolism that appears in portraits of the Virgin Queen, though her iconography embraced a number of these images from the 1570s onward. Nicholas Hilliard's paintings in particular reveal as much about his own chymical interests as the queen's reputation for them, suggesting that the overlap in symbolism was no accident.

Hilliard (c. 1547-1619), one of Elizabeth's trusted artists who gained fame as a miniaturist, employed chymical iconography in a number of his works. He may have been exposed to chymical techniques from a young age given his father's occupation as a goldsmith; the painter later gained expertise during his apprenticeship to Robert Brandon, the queen's jeweler and goldsmith. ${ }^{79}$ Even his very trade as a miniaturist derived its name from the raw materials provided by God's creation. The Latin minium referred to the red lead used to embellish illuminated manuscripts. ${ }^{80}$ Evidence reveals that Hilliard harbored an interest in chymistry. In 1601 Thomas Harrison came under examination because a parcel he sent to France had been intercepted. It contained a remarkable wooden and metal box decorated with the portrait of a woman, possibly Elizabeth. He

saith that the metal is of mercury congealed with vinegar and verdigris, and was made by Mr. Hillyard about eight or nine years since... he further saith that the metal of the picture was made by Mr. Hyllyard, and will with aqua fortis be dissolved again into quicksilver, and he saith that the said picture was made about the time that Mr. Hillyard did make models for the great seal in the time of Sir Christopher Hatton. ${ }^{81}$

This last remark confirms the identity of "Mr. Hillyard", as Nicholas Hilliard had designed the second and third great seals of the realm in 1584 and 1591 , respectively. ${ }^{82}$ This passage indicates that during the 1590 s, at least, he engaged in chymical activities. While

\footnotetext{
${ }^{79}$ Erna Auerbach, Nicholas Hilliard (London: Routledge and Kegan Paul, 1961): 33; Mary Edmond, "Nicholas Hilliard (1547?-1619)," ODNB, online edn. [http://www.oxforddnb.com/view/article/13320, accessed 3 September 2010].

${ }^{80}$ Edmond, "Nicholas Hilliard," $O D N B$.

${ }^{81}$ Examination of Thomas Harrison, 4 October 1601 in R.A. Roberts (ed.), CMS, Vol. 11 (London: 1906): 405 .

${ }^{82}$ Edmond, "Nicholas Hilliard," $O D N B$.
} 
Helen Hackett and Louis A. Montrose have explored Harrison's examination in the context of recusants abusing images of the queen, this proof of Hilliard's chymical expertise has previously been overlooked. ${ }^{83}$ The miniaturist received training in a variety of visual arts and crafts, and from Harrison's testimony we learn that he augmented his painting skills and knowledge of goldsmithery with chymical techniques. In 1594, not long after Harrison claimed he had crafted the congealed mercury box, Hilliard intervened on behalf of Abel Fecknam, a goldsmith facing execution for chymical coining. ${ }^{84}$ These events put into context the iconography he developed for Elizabeth two decades earlier.

Hilliard painted two distinctive portraits of the queen between 1572 and 1576 . The "Pelican" and "Phoenix" paintings first suggest his familiarity with the chymical process. Roy Strong has identified these linked images as the earliest portraits to "indicate any kind of personal iconography" — and the first to utilize these particular symbols, which would become commonplace. ${ }^{85}$ Structurally, Hilliard's early portraits function as a reflecting pair. Both represent the sanctity and authority of Elizabeth's ruling government as well as motherly love for her people.

Medieval legends about the pelican extended into the early modern era.

Elizabethans believed that the pelican would pierce her own breast to provide blood and nourishment for her young. This selfless willingness to wound herself for the sake of others led to a widespread association with self-sacrifice, atonement and charity. Another version of the pelican legend had the "life-rendering" bird killing her young and then resurrecting them. ${ }^{86}$ Thus the pelican had long evoked the passion of Christ, as in Thomas Aquinas's hymn "Adoro Te Devote". ${ }^{87}$ In Elizabeth's case it suggested sacrifice motivated by devotion to her subjects. Among chymists, however, a different set of

\footnotetext{
${ }^{83}$ See Hackett, Virgin Mother, 211-3; and Louis A. Montrose, "Idols of the Queen: Policy, Gender, and the Picturing of Elizabeth I" in Representations, No. 68 (1999): 113-4.

${ }^{84}$ See HMC Salisbury, iv, p. 490: Hilliard to Sir Robert Cecil, 16 March 1594, referenced in Parry, ArchConjuror, Ch. 20. On Fecknam's pardon, see TNA: SP 12/249 f.38.

${ }^{85}$ Strong, Gloriana, 81-2.

${ }^{86}$ William Shakespeare, Hamlet (1599-1601), 4.5.146.

${ }^{87}$ Mary T. Clark, ed., An Aquinas Reader (Bronx: Fordham University Press, 2000): 441.
} 
meanings prevailed. They connected the bird with the red elixir during the penultimate stage of the Great Work, cohobation or the multiplicatio. During this part of the process, the chymist augmented the elixir with mercurial water, thereby nourishing it and increasing its potency. ${ }^{88}$ As we will see in Grace Mildmay's writings, the pelican also gave her name to a distinctive chymical vessel, which resembled a bird piercing her own breast. The prevalence of chymical activity during the Elizabethan era meant that these interpretations were widely known. Pelican imagery would become popular among New Year's gifts for the queen, beginning with a necklace from Mary Dudley Sidney in 1573: "one juell of golde, wherein is a pellycane garnished with smale rubyes and diamondes". 89 She may have been acquainted with Hilliard, who, nearly two decades later, would paint a miniature of her daughter and namesake.

The phoenix, another common Renaissance emblem, simultaneously alluded to the queen's chastity and asserted the legitimacy of hereditary rule. ${ }^{90}$ The association would endure; Shakespeare posthumously described Elizabeth as "the maiden phoenix" rising from her father's ashes in Henry VIII. ${ }^{91}$ That the first literary reference to this mythical creature with respect to the queen came in 1580 with Lyly's Euphues and his England may lend credence to the possibility that the symbol derived from chymical texts. ${ }^{92}$ Like the pelican, the phoenix represented the multiplicatio. It was one of four birds that symbolized the primary stages of the chymical opus. The self-immolating, self-regenerating phoenix came to be associated with the resurrection of the previously white stone as red during the rubedo, the final stage of the chymical opus whereby the purified matter of the stone is reunited with its spirit in the supreme chymical wedding. ${ }^{93}$

\footnotetext{
${ }^{88}$ Abraham, Dictionary, 40-1, 143-4.

${ }^{89}$ Nichols, Progresses, Vol. I, 324.

${ }^{90}$ Kantorowicz, King's Two Bodies, 385-401 and 413-5.

${ }^{91}$ William Shakespeare, Henry VIII (1612-3), 5.4.40.

${ }^{92}$ Strong, Gloriana, 83.

${ }^{93}$ Abraham, Dictionary, 152, 174-5.
} 
These images persisted through Elizabeth's reign. The Phoenix Medal (ca.

1574) found the fiery bird opposite a one-quarter profile of the queen, quite literally two sides of the same coin. ${ }^{94}$ Hilliard himself employed the phoenix again in the lid of his Drake Jewel of 1586-7, and a 1595 engraving by Crispin van de Passe the Elder combined the two symbols. ${ }^{95}$ This iconic piece emphasizes Elizabethan England's imperial vision: a pelican feeds her young on a column to the left of the queen, while flames engulf a phoenix perched on the corresponding right-hand column.

The "Pelican" and "Phoenix" images were not Hillard's only contributions to chymical representations of the queen. He and his assistants painted Elizabeth surrounded by a subtle bestiary in the 1584 Charter for Emmanuel College, Cambridge, which depicts a snake entwined around springtime blooms while a parrot, butterfly and snail adorn the queen's throne. ${ }^{96}$ As further indicated by her rather hemispherical skirt, the Charter, too, concerns itself with English imperialism. The exploration (and exploitation) of nature constituted an important aspect of that vision, providing a clear link to chymistry.

Hilliard's workshop played upon the same concept with the queen's remarkable gown in the "Hardwick" portrait (ca. 1599). ${ }^{97}$ Decorated with flora and fauna both real and imagined, Elizabeth wears the natural world and thus echoes Dame Nature herself. During her reign naturalists utilized efficient networks of travel and communication to share new discoveries. ${ }^{98}$ Hilliard implied that she possessed extensive knowledge of the sphere she inhabited, consistent with her reputation as a learned monarch. His chymical experimentation lends this symbolism added significance. The "Hardwick" painting furthermore features the mask of youth Hilliard developed for the queen in the 1590s. Part of a "policy of deliberate rejuvenation", his new imagery accompanied the officially

\footnotetext{
${ }^{94}$ See Strong, Gloriana, 82.

${ }^{95}$ Reproduced in Strong, Gloriana, 120.

${ }^{96}$ Reproduced in Strong, Gloriana, 111 (Fig. 106).

${ }^{97}$ Reproduced in Strong, Gloriana, 151 (Fig. 168).

${ }^{98}$ See Deborah Harkness, The Jewel House: Elizabethan London and the Scientific Revolution (New Haven: Yale University Press, 2007), esp. 15-56.
} 
sanctioned destruction of royal portraits she found offensive. ${ }^{99}$ By portraying Elizabeth as eternally youthful, Hilliard and other artists could effect a kind of alchemical transformation, granting the queen immortality and honor so long as the work survived. This tactic may have been motivated by self-preservation on the part of the painters, but it contributed to Elizabeth's goddess-like image.

Similarly, a 1586/7 Hilliard miniature depicting the queen with a lunar jewel and arrows for hair ornaments marked the inception of her identification with Diana or Cynthia in art. ${ }^{100}$ It should be noted that the chaste goddesses associated with Elizabeth all presided over watery domains. ${ }^{101}$ They echo a rarely mentioned 1565 Flemish medal that represented the queen as "Divine fountain of the realm" in a Greek anagram of her name. ${ }^{102}$ The fountain in particular signified aqua permanens, what twelfth-century chymist Artephius described as "the royal fountain in which the king and queen bathe themselves" in his Secret Book, and water, as one of the four elements, more generally described dissolved philosophical mercury. ${ }^{103}$ Of course, these familiar symbols had other associations; their application in Elizabethan imagery may have been coincidental, but they would certainly have resonated with those acquainted with chymical texts, including Hilliard himself.

Though written years after Queen Elizabeth's death, the emblematic 1617 work Atalanta fugiens synthesized fundamental principles that held true during her reign. Its author, the German chymist and physician Michael Maier (1568-1622), emphasized the necessity of combining practice and theory, which he termed "hand" (praxis) and "head" (gnosis). ${ }^{104}$ The ubiquity of Elizabeth's hands in royal portraits provides a useful, if

\footnotetext{
${ }^{99}$ Strong, Gloriana, 20 and 147.

${ }^{100}$ Walter Raleigh developed this association. See Strong, Gloriana, 125-6.

${ }^{101}$ Ibid., 126.

${ }^{102}$ Hester Lees-Jeffries, "Location as Metaphor in Queen Elizabeth's Coronation Entry (1559): Veritas Temporis Filia" in Jayne Archer, Elizabeth Goldring and Sarah Knight, eds., The Progresses, Pageants and Entertainments of Queen Elizabeth I (Oxford: Oxford University Press, 2007): 79.

${ }^{103}$ Abraham, Dictionary, 81, 213.

${ }^{104}$ Quoted in Jayne Elisabeth Archer, "Women and Alchemy in Early Modern England" (PhD dissertation, Cambridge University, 1999): 1.iv.
} 
unintentional, illustration of this relationship. Roy Strong has noted a scholarly tradition attributing such prominence to their famed beauty — and the queen's vanity. ${ }^{105}$ Exquisite though they may have been, her hands represented agency that the learned monarch was singularly qualified to direct. They counter the passivity of Elizabeth's face with the ability to act, write and rule. The very conspicuous presence of her hands in portraits suggests that the queen's activities and interests influenced her iconography. By applying Maier's analogy to Elizabethan royal art, we find that the practical and symbolic aspects of chymistry constituted less a dichotomy than a continuum in which the two interacted with and informed one another.

Other artists joined Nicholas Hilliard in associating the queen with chymical symbols. New information has recently come to light about a relatively unknown painting at the National Portrait Gallery. NPG 200, which for convenience I will call the "Mines Royal" portrait, depicts Elizabeth resplendent in a jeweled golden gown, a small spray of roses in her right hand. ${ }^{106}$ The work of an unknown artist, it dates to the 1580 s or early 1590s. Degradation and paint loss have led art historian Tarnya Cooper and her colleagues to conclude that the queen originally clasped a coiled snake. ${ }^{107}$ Paint analysis supports this hypothesis, indicating that the serpent was painted at the same time as the rest of the piece.

As shown above, snakes appeared from time to time in representations of the queen, generally symbolizing her wisdom, prudence and level-headed judgment. The "Mines Royal" portrait predated Isaac Oliver's prominent "Rainbow" design (ca. 1600), in which a jeweled snake with a ruby heart pendant dangling from its mouth adorns the queen's sleeve. ${ }^{108}$ In the guise of wisdom, this serpent implies that the queen's head keeps her heart or passions in check. The fact that either the artist or the patron who

\footnotetext{
${ }^{105}$ Many of these paintings are reproduced in Strong, Gloriana. See, for instance, 25-8, 60-1.

${ }^{106}$ See the National Portrait Gallery website [http://www.npg.org.uk/collections/search/portrait.php?search=ap\&npgno=200, accessed 23 August 2010].

${ }^{107}$ See the National Portrait Gallery news release, 4 March 2010 [http://www.npg.org.uk/about/press/queenelizabeth-i-press.php, accessed 23 August 2010].

${ }^{108}$ Reproduced in Strong, Gloriana, 156 (Fig. 172).
} 
commissioned the "Mines Royal" portrait deemed it necessary to remove the snake suggests an unwanted association with the wrong kind of knowledge: that offered by the Biblical serpent. Evidently someone believed the image might be misconstrued. The decision to replace it with the more innocuous roses, frequently associated with the queen and themselves chymically significant, deserves greater recognition and attention.

Myriad meanings testify to the vitality of the snake as a chymical symbol. As Mercurius, the serpent appears in two guises, represented by the winged male and wingless female of the hermetic caduceus. The self-generating and -devouring ouroboros symbolizes the circular nature of the chymical opus. Lyndy Abraham has also noted associations with the ancient substance at the inception of the Great Work, the corrupt matter and the purified prima materia it becomes - the very focus of Queen Elizabeth I's mining monopoly companies. ${ }^{109}$

The source of the "Mines Royal" portrait indicates that the chymical significance of snakes should not be overlooked. The Society of Mines Royal and Company of Mineral and Battery Works presented the painting to the National Portrait Gallery in 1865. Elizabeth incorporated these two companies, which would later merge, in 1568. The former had a monopoly for base metals in several English and Welsh counties, including Cumberland, while the latter, based on a 1565 patent granted to William Humfrey, mined "royal metals" like gold and silver, minerals and produced battery ware. ${ }^{110}$ They also extracted copper using hydrometallurgy and cementation on scrap iron — processes then perceived as chymical — and produced mixed metals such as "latten", a natural alloy chymically affiliated with philosophical mercury and the green lion. ${ }^{111}$ Leicester, William Cecil, the earl of Pembroke and James Blount, Lord Mountjoy, who long sought the

\footnotetext{
${ }^{109}$ Abraham, Dictionary, 181.

${ }^{110}$ See TNA: SP 12/37 f.123, September 1565, 259; SP 12/41 f.55, 22 November 1566, 283; SP 12/75 f.20, 1570, 398; William Rees, Industry Before the Industrial Revolution: Incorporating a Study of the Chartered Companies of the Society of Mines Royal and of Mineral and Battery Works, 2 Vols. (Cardiff: University of Wales Press, 1968).

${ }^{111}$ See "leaching" in "Copper processing", Encyclopedia Brittanica (2006), at Encyclopedia Brittanica Online; Abraham, Dictionary, 114-5.
} 
philosopher's stone, all held shares in the Mines Royal. ${ }^{112}$ This connection to the raw materials with which chymists began their work makes the painting all the more intriguing. The "Mines Royal" portrait thus ties colorful chymical symbolism back to the practical benefits chymistry offered in a way that mirrors the queen's own role.

The scope of this project has not permitted a truly comprehensive examination of chymical symbolism in images of Elizabeth, which deserves to be undertaken. Other images of chymical significance should be noted. For instance, her portrayal as Pax recalls the harmony attained when the male and female principles unite in the chymical wedding. ${ }^{113}$ The aforementioned "Rainbow" portrait attributed to Isaac Oliver bears the inscription "Non sine sole iris", asserting that there can be no rainbow without the sun. The latter, gendered male in chymical texts, signifies Elizabeth herself in a nod to the notion of the queen's two bodies, suggesting what Strong has termed a "cosmic control of the elements" that connects back to traditional royal powers. Such chymical emblems should be examined in the context of the Elizabethan preoccupation with transmutation; they bear witness to the queen's chymical expertise and its impact on her subjects, some of whom I turn to in the remaining chapters.

Queen Elizabeth engaged with the chymical world throughout her life. Her learned tutors ensured that she knew of the quest for the philosopher's stone from a young age, and she familiarized herself with chymical language, techniques and practitioners accordingly. Financial concerns soon justified Elizabeth's intellectual curiosity. She hoped to bolster the royal treasury with the royal art, following in the footsteps of her predecessors.

Conscious of the debt she had inherited, she established metallurgical organizations and employed men like the Hogans and Cornelius de Lannoy. William Cecil, Robert Dudley

\footnotetext{
112 TNA: SP 12/144 f.70, 19 November 1580. See also SP 12/77 f.63, 24 March 1571. On Mountjoy and chymistry, see Sir Robert Naunton, Fragmenta regalia, or, Observations on the late Queen Elizabeth, her times and favorites (London, 1641): 37.

${ }^{113}$ See Strong, Gloriana, 113-4.
} 
and others close to the queen shared her preoccupation with transmutation. Elizabeth believed in the efficacy of chymistry throughout her reign, reserving her doubts for the ethics and abilities of those who sought her patronage. Chymistry's esoteric qualities tend to attract more attention than the reality of the rewards it offered, but the pragmatic benefits provided by the stone were precisely what attracted Elizabeth and her court to the subject.

The queen's self-presentation and portraiture reveal that the vivid imagery and resonant symbols of chymistry played a significant role in Elizabeth's iconography. As a female ruling monarch, she acknowledged the critical importance of gender by embracing the notion of the king's two bodies, which afforded her unprecedented versatility. Elizabeth's affiliation with chymical symbols and goddess figures like Lady Alchymia reflected both enduring chymical interests and her role as a royal mediator between the human and the divine, earth and heaven, female and male. Significantly for the subjects of this thesis, such representations allowed her to transcend the perceived weakness of her natural body without denying her sex. Elizabeth thus acted as a bridge by which her female subjects could access the chymical world themselves. The following chapters explore these interactions from the perspectives of Elizabethan gentlewomen inspired by their queen. Each woman had close ties to the court, having served in Elizabeth's privy chamber or counting the queen's trusted servants among their friends and relations. 


\section{Chapter 2}

\section{Grace Mildmay}

Lady Grace Mildmay (c. 1552-1620) left to her descendents a substantial and, according to contemporary belief, practical body of medical advice. A childhood emphasis on healing knowledge and marital connections to Elizabeth's court guided the gentlewoman to chymistry. She bestowed upon her daughter and grandchildren a legacy of godly beliefs and actions with her brief autobiography, devotional writings and medical papers: “Thus have I given my mind unto my offspring as my chief and only gift unto them". 1 These manuscripts, totaling more than 1,200 folios, provide clear evidence not only of Mildmay's chymical expertise, but also of the extent to which her charitable healing, iatrochemistry and Protestant beliefs informed each other. Lady Grace's writings testify to a significant connection between the religiously motivated perception of a sinful, decaying world and the chymical themes of renewal and restoration. The certainty that human failings had caused a decline in nature provided a powerful impetus for the study and practice of chymistry, particularly in women, whose reputations as healers and nurturers shaped their approach to life. In Grace we find the queen's chymical influence manifested.

Lady Mildmay’s contemporaries admired her skills as a healer. In his 1622 work $A$ Treatise of One Hundred and Thirteene Diseases of the Eyes, physician and oculist Richard Banister excluded Grace from his attack on female medical practitioners:

I have known some, whose worth and wisdome might be paraleld with principall men; whose cures were attended with due care, and ended with true charity: as the right religious and vertuous Lady, the Lady Mildmay, of Apethorpe in the county of Northhampton, who had her selfe good judgement in many things; yet when the poore came home to her for help (for on such people she did plant her practice) in cases of Physicke, she

\footnotetext{
${ }^{1}$ Linda Pollock, With Faith and Physic: The Life of a Tudor Gentlewoman (Collins and Brown: London, 1993): 71.
} 
would use the approbations of a Physician; in Chirurgerie, the aide of a Chirurgeon and for the eyes, the assistance of my selfe. ${ }^{2}$

Banister emphasized Grace's charitable nature and willingness to seek advice from those better qualified in particular areas. She sought to improve her own skills and the services she offered to patients by consulting with those who presumably knew best. Further evidence that Lady Grace's talent for healing was publicly known more than a generation after her death comes with her inclusion in the 1655 publication The Queens Closet Opened, which purports to contain recipes used in the royal kitchen. ${ }^{3}$ A portrait of Queen Henrietta Maria, wife of Charles I, appears on the frontispiece of this work, but the title's ambiguous punctuation refers back to predecessors such as Elizabeth and Anne. " ${ }^{4}$ "The Lady Mildmayes Drink for Cough or Cold" is a rather traditional tonic of licorice, aniseed, raisins, figs, hyssop and coltsfoot in honey. By way of corroboration, aniseed appears in her list of medical attributes of plants for the head, and she included both licorice and hyssop among those plants beneficial to the breast and lungs. ${ }^{5}$

Lady Mildmay's medical papers reveal that she augmented traditional Galenic techniques with Paracelsian theory and chymical ingredients. Significantly, neither she, nor her daughter Mary, nor subsequent generations observed a conflict between these practices and her devout Protestantism. This chapter first examines Grace's approach to medicine before turning to its impact on her spiritual meditations, which reflect a previously overlooked eschatological stance akin to Paracelsus's own. Such apocalyptic hopes and fears, which situate her in the wider chymical world, may have motivated her medical practice.

\footnotetext{
${ }^{2}$ Richard Banister, A Treatise of One Hvndred and Thirteene Diseases of the Eyes, and Eye-Liddes (London, 1622): To the Reader.

${ }^{3}$ W.M., The Queens Closet Opened (London, 1655): 164.

${ }^{4}$ Jayne Archer, "The Queens' Arcanum: Authority and Authorship in The Queens Closet Opened" in The Renaissance Journal, Vol. 1, No. 6 (2002).

${ }^{5}$ Pollock, With Faith, 127.
} 
Along with her autobiography and meditations, Grace Mildmay left her medical papers to her daughter, who recognized in them a "treasure of this my worthy mother's mind", she "who spent a great part of her days in the search and practice thereof". 6 This practice had begun in childhood. Grace was the second of three daughters born to Sir Henry Sharington and his wife Anne Paget. ${ }^{7}$ In 1553, upon the death of his brother, her father inherited Lacock Abbey near Chippenham, and he moved his family from Norfolk to Wiltshire. The household included Sir Henry's niece, Mistress Hamblyn, whom his wife had raised; she was granted the responsibility of educating the Sharington girls. From her the sisters learned more than the usual skills we have come to expect from gentlewomen-in-training. Grace noted that Hamblyn possessed "good knowledge in physic and surgery" - knowledge that she passed on to at least one of her young charges. ${ }^{8}$

The Sharington girls were raised to perceive inactivity as inherently sinful. Whenever Mrs. Hamblyn saw Grace “idly disposed”, she advised her to read “Dr Turner's herbal and in Bartholomew Vigoe", references to William Turner's then two-volume Herball and Bartholomew Traheron's translation of a surgical text by Giovanni da Vigo.' Hamblyn's other great gift to the girls reflected Lady Sharington's training: dedication to divinity. The pervasiveness of the family's Protestant inclinations extended to all aspects of life. For Grace and her family, medical practice was not only consistent with their religious beliefs but a natural extension of them. By healing, Mistress Hamblyn and the Sharingtons transformed good thoughts into good works, all in God's name.

As an adult, Grace had the freedom and leisure to develop her medical knowledge. In 1567 she married Anthony Mildmay, the elder of Sir Walter Mildmay's two sons with

\footnotetext{
${ }^{6}$ Ibid., 110.

${ }^{7}$ Linda Pollock, "Lady Grace Mildmay (c. 1552-1620)," ODNB, online edn. [http://www.oxforddnb.com/view/article/45817, accessed 11 November 2009].

${ }^{8}$ Pollock, With Faith, 26.

${ }^{9}$ Ibid., 26, 97 n. 32. See Giovanni da Vigo, The most excelent worckes of chirurgery, Bartholomew Traheron, ed. (London, 1550); William Turner, A new herbal (London, 1551); The seconde part of VVilliam Turners herball (London, 1562); and The first and seconde partes of the herbal of William Turner Doctor in Phisick, lately ouersene, corrected and enlarged with the third parte (Cologne, 1568).
} 
his wife Mary, the sister of Sir Francis Walsingham. Still a teenager himself, Anthony was dissatisfied with the arrangement, "being then more willing to travel to get experience of the world than to marry so soon". ${ }^{10}$ He spent a great deal of time apart from his new bride, and kept up the habit for subsequent decades. He combated the northern rebellion in 1569 and accompanied his uncle Walsingham to the Low Countries on a special embassy in 1578; not until 1596 did he receive a knighthood, coinciding with his appointment as coambassador extraordinary to France. ${ }^{11}$ Grace and Anthony had only one child, a daughter named Mary who was born, unusually, more than a decade after her parents were wed. Despite its inauspicious start and the apparent lack of love in their marriage, fifty years together seem to have resulted in mutual respect and affection, as indicated by Anthony's will. He appointed his "welbeloved wyfe" as sole executrix. ${ }^{12}$

The Mildmays, like the Sharingtons, advocated Protestantism. In Anthony's absence Grace lived in Apethorpe, Northamptonshire, with her mother- and father-in-law, whose influence she felt deeply. Through Sir Walter in particular she maintained close ties with the court, where the queen led the fashion for chymical pursuits. ${ }^{13}$ A moderate Puritan and close friend, neighbor and colleague of William Cecil, Sir Walter served under four Tudor monarchs, gaining particular recognition from Queen Elizabeth, who in 1559 appointed him chancellor of the exchequer. In return, his oratorical skills and parliamentary panegyric would contribute to the cult of Elizabeth. ${ }^{14}$ Sir Walter's own propensity for charity and emphasis on humanist education suggests that he would have supported his daughter-in-law's informed pursuit of medical knowledge.

\footnotetext{
${ }^{10}$ Pollock, With Faith, 32.

${ }^{11}$ L.L. Ford, "Sir Anthony Mildmay (c. 1549-1617)," ODNB, online edn. [http://www.oxforddnb.com/view/article/18696, accessed 16 May 2010]. 12 Ibid.

${ }^{13}$ They also provide tenuous links to the other subjects of this thesis: Sir Walter was close friends with Philip Hoby, Margaret Hoby's late uncle through marriage, and Lady Mary's niece, Frances, married Mary Sidney Herbert's brother Philip in 1583.

${ }^{14}$ L.L. Ford, "Sir Walter Mildmay (1520/1-1589)," ODNB, online edn. [http://www.oxforddnb.com/view/article/18696, accessed 16 May 2010].
} 
Although Grace bequeathed her papers "scatteringly and confusedly", their contents were logically arranged, indicating that she approached medicine in a systematic way. ${ }^{15}$ Pollock's publication on Mildmay includes forty percent of these medical papers, which tell us a great deal about her practice. Grace organized diseases by the primary parts of the body they afflicted, beginning with the head. In her entry on melancholy, she acknowledged that it was "the forerunner many times of the two last diseases [frenzy and madness] and therefore might challenge to have precedency here of them". ${ }^{16}$ Similarly, she observed that memory decay often heralded other "stupefying" diseases. ${ }^{17}$ Lady Mildmay's articulation on this matter indicates that she gave thought to the structure of her papers, a necessity should she wish to consult them on a regular basis. She described conditions and treatments in a coherent, consistent way, noting connections between them and presenting the receipts in an order that reflected those links. We see a similar pattern in her list of medical attributes of plants, which have been grouped according to the body parts that they were most commonly used to treat. Grace further subdivided them into roots, herbs, seeds, flowers, spices and bark. ${ }^{18}$

Her first recipe, for a "most precious and excellent balm", reveals that she planned her treatments just as carefully. ${ }^{19}$ Lady Mildmay grouped the ingredients by source and function, a necessity given this balm's complexity. It required twenty-four roots, sixtyseven different herbs, fourteen seeds, a dozen types of flower, ten spices, twenty-four gums, six purgatives, with which she grouped vinegar, oil and sugar, and five cordials, all at a cost of more than ten pounds, a not insubstantial fee. To prepare this elaborate concoction, she infused the herbs and roots for a minimum of six days before distilling the liquid three times and straining, and then repeated this process with the addition of the

\footnotetext{
${ }^{15}$ Pollock, With Faith, 110.

${ }^{16}$ Ibid., 120-1.

${ }^{17}$ Ibid., 115-6.

${ }^{18}$ Ibid., 127.

${ }^{19}$ Ibid., 128.
} 
spices and gums. Lady Grace claimed that this balm could be used "many ways outward and inward... You may make it agreeable for every purpose". ${ }^{20}$ Though she believed that this particular cure acted as a panacea, most of the ointments, plasters, syrups, lotions, juleps, tinctures and essences in her papers targeted specific ailments.

Lady Mildmay took a comprehensive approach to patients, incorporating case histories and details on the treatments she prescribed. An entry on a twenty-five-year-old woman "perfectly cured" of the epilepsy that had plagued her since childhood is typical. Mildmay noted her ultimately successful course of treatment over a nearly three-year period, which included preparatives, sweats, balms, purgatives and dietary changes. ${ }^{21}$ She furthermore took the specifics of a patient's condition into account, considering the "age, youth, nature, custom and hability of the patient". ${ }^{22}$ Subsequent recipes highlight this fact with the qualifier "according to the strength of the party". ${ }^{23}$ Her formula for laudanum specifies that oil of nutmegs should only be included for male patients due to its toxicity for women. ${ }^{24}$ She also recognized the importance of diet and routine with respect to the efficacy of any treatment. ${ }^{25}$

Lady Grace targeted both the causes and symptoms of illness. Her entry on melancholy illustrates this clearly. She believed that the condition derived either from the "predominance of that humour [melancholy] in the blood in the brains itself[,]...from the same in the veins sending vapours thither", or "from the vapours arising from inflammations about the stomach and sides". ${ }^{26}$ The following paragraph describes the signs of each, which vary based on the source of the imbalance. For example, fearfulness and a slow pulse would indicate the first of the three causes. Grace's entry on the falling sickness is structured similarly, indicating that not only did she treat both physical and

\footnotetext{
${ }^{20}$ Ibid., 130.

${ }^{21}$ Ibid., 112-3.

22 Ibid.

${ }^{23}$ See, for example, ibid., 135 (from "The blood or oil of antimony”).

${ }^{24}$ Ibid., 136.

${ }^{25}$ Ibid., 112 ("order and diet much furthereth or hindereth the operation of physic").

${ }^{26}$ Ibid., 121.
} 
mental illnesses, but she also approached them in a parallel manner. This, too, was holistic: "they who minister physic must take care and consideration of all humours and all parts, that will truly cure any one". ${ }^{27}$ The medical papers suggest that Grace followed her own maxim.

Her frequent mentions of "humours" suggest familiarity with the Galenic and Hippocratic approaches to disease favored by humanists and universities. ${ }^{28}$ Galen's teachings held that a person's health hinged on the balance of four humors (blood, phlegm, black bile and yellow bile), which varied according to gender and season and changed over time. Interactions between these humors and the four elements composing the world earth, air, fire and water — defined temperament; people could be choleric (hot and dry), sanguine (hot and moist), melancholic (cold and dry) or phlegmatic (cold and moist). Women tended to be colder and moister than men, and the elderly typically were colder and dryer than the young. Any disruption of the humoral balance resulted in disease. Practitioners preferred to restore a patient's equilibrium with purges, vomits and techniques like blood-letting, adhering to a principle of opposites. In order to expel an overabundance of heat, for instance, a cold medication was needed. They consulted classic texts by Hippocrates, Galen and Avicenna as well as traditional herbal and astrological lore. Grace's papers incorporate a variety of Galenic treatments and she acknowledged astrological influences in her approved course for frenzy. ${ }^{29}$ Her acknowledgement that diet and exercise can impact health echoes their own emphasis on moderation. She too preferred to avoid excess: "It is [a] dangerous thing to wear and distract the humours in the body by extreme purges or extreme cordials". ${ }^{30}$ However, unlike Lady Mildmay, purely

\footnotetext{
${ }^{27}$ Ibid., 111.

${ }^{28}$ See, for instance, ibid., 94; Margaret Pelling and Charles Webster, "Medical practitioners" in Health, Medicine, and Mortality in the Sixteenth Century, ed. Charles Webster (Cambridge: Cambridge University Press, 1979): 202; Lucinda Beier, Sufferers and Healers: The Experience of Illness in Seventeenth-Century England (London: Routledge \& Kegan Paul, 1987): esp. 30-2, 35, 213; Peter Harrison, The Bible, Protestantism and the Rise of Natural Science (Cambridge: Cambridge University Press, 1998): 65, 194. ${ }^{29}$ Pollock, With Faith, 119.

${ }^{30}$ Ibid., 110.
} 
Galenic adherents attended only to a disease's symptoms, and not its root cause, which they considered unknowable.

Grace's medical papers indicate that she also embraced iatrochemistry, including aspects of the system espoused by the itinerant Swiss reformer Phillippus Aureolus Theophrastus Bombastus von Hohenheim, or Paracelsus (1493-1541). ${ }^{31}$ This combination would have scandalized many contemporary physicians as well as Paracelsus himself. He challenged Galenism with hermetic and Neoplatonic philosophies that emphasized the value of experience over knowledge obtained from books. Paracelsus viewed disease not as an internal imbalance but the result of an external influence damaging the body's spirit or archeus. He replaced the traditional fourfold elemental system with a triad: salt, sulphur and mercury. ${ }^{32}$ Like the Neoplatonists, the Paracelsian cosmology relied upon an analogy between man as microcosm and the macrocosmic universe. More than a medical theory, Paracelsus espoused a coherent worldview with explicit religious and apocalyptic overtones. He and his followers considered Galenism a corruption of Adam's postlapsarian medicine, with nature the true source of divine wisdom. His emphasis on the justification of faith through works resonated with early modern Protestants like Grace. ${ }^{33}$ The Paracelsians approached illness with a doctrine of sympathy rather than antipathy, and believed that disease could be treated retrospectively. There was a sense of specificity in this type of treatment, which attempted to localize what had previously been viewed as an affliction of the entire body. In addition to vomiting, purging and sweating, they utilized chymical ingredients to treat patients.

\footnotetext{
${ }^{31}$ On Paracelsus, his beliefs and those of his followers, see, for example, Charles Webster, Paracelsus: Medicine, Magic and Mission at the End of Time (New Haven: Yale University Press, 2008): 132-9; Charles Webster, "Alchemical and Paracelsian medicine" in Health, Medicine, and Mortality in the Sixteenth Century, ed. Charles Webster (Cambridge: Cambridge University Press, 1979): 301-34; Walter Pagel and Pyarali Rattansi, "Vesalius and Paracelsus" in Medical History, Vol. 8, No. 4 (1964): 309-28; Pollock, With Faith, 94-6; Anthony Fletcher, Gender, Sex \& Subordination in England, 1500-1800 (New Haven: Yale University Press, 1995),: 289; Harrison, The Bible: 105, 185, 194; William Newman, Promethean Ambitions: Alchemy and the Quest to Perfect Nature (Chicago: University of Chicago Press, 2005): 107-8, 201-3.

${ }^{32}$ Webster, Paracelsus, 132-9.

${ }^{33}$ Pollock, With Faith, 95.
} 
Lady Mildmay, too, deployed minerals and metals for medicinal purposes. ${ }^{34}$ She incorporated both quicksilver, the female principle, and sulphur or brimstone, the male. ${ }^{35}$ Gold, alum, pearls, antimony, saltpetre and other common iatrochemical components appear in her medicaments. She used them to treat serious afflictions as well as cosmetic concerns, acknowledging that "defects of [the face] being most visible, justly deserveth the more diligent search of cure". ${ }^{36}$ The panacea mentioned earlier required aqua vitae or "water of life", distilled alcoholic spirits that chymists believed acted as a catalyst for the Great Work. ${ }^{37}$ Grace prepared it in bulk, using a recipe that called for ten gallons of ale infused with three pounds of aniseed and licorice. ${ }^{38}$ Her medical papers strongly indicate that she accepted the validity of Paracelsian and iatrochemical treatments alongside the more traditional Galenic cures.

Lady Mildmay's laboratory or stillroom was equipped with a range of apparatus, many familiar to chymists. Her discussion of these vessels shows that she took care to ensure the reproducibility of her treatments. Grace's recipes frequently refer to her "limbeck" (alembic), crucible, "matrass which hath a long neck" and pelican, a circulatory still resembling the symbolic bird discussed in the previous chapter (Figure 2). ${ }^{39}$ Furthermore, her claim that "I have wont to do it in a vessel of glass, well luted", or sealed, shows that practical knowledge informed these recipes; she also recognized earthen vessels as a more cost-effective alternative. ${ }^{40}$ We find several references to a "balneum marie", the double boiler invented by the legendary Maria the Jewess. Numerous inclusions of a phrase typically associated with chymistry — "according to art" — reinforce this

\footnotetext{
${ }^{34}$ Ibid., 131-5 and 140 .

${ }^{35}$ Lyndy Abraham, A Dictionary of Alchemical Imagery (Cambridge: Cambridge University Press, 1998): 162, 192-4.

${ }^{36}$ Pollock, With Faith, 125. On beauty and medicine, see Edith Snook, "'The Beautifying Part of Physic': Women's Cosmetic Practices in Early Modern England” in Journal of Women 's History, Vol. 20, No. 3 (2008): 10-33.

${ }^{37}$ Abraham, Dictionary, 9.

${ }^{38}$ Pollock, With Faith, 137-8.

${ }^{39}$ Ibid., 132-5. See Abraham, Dictionary, 143.

${ }^{40}$ Pollock, With Faith, 134. Abraham, Dictionary, 120.
} 
connection. ${ }^{41}$ The presence of such language, embedded with implied knowledge and skill, points to her acquaintance with chymists or texts on the subject. Not well known in England until the latter half of the sixteenth century, Paracelsian theories gained popularity through distiller John Hester's translations, published between 1579 and 1591, and chymical apologist Richard Bostocke's 1585 work The difference between the auncient phisicke... and the latter phisicke. ${ }^{42}$ Grace may have learned about Paracelsus through these publications or a local physician familiar with them.

Figure 2: Pelican vessel

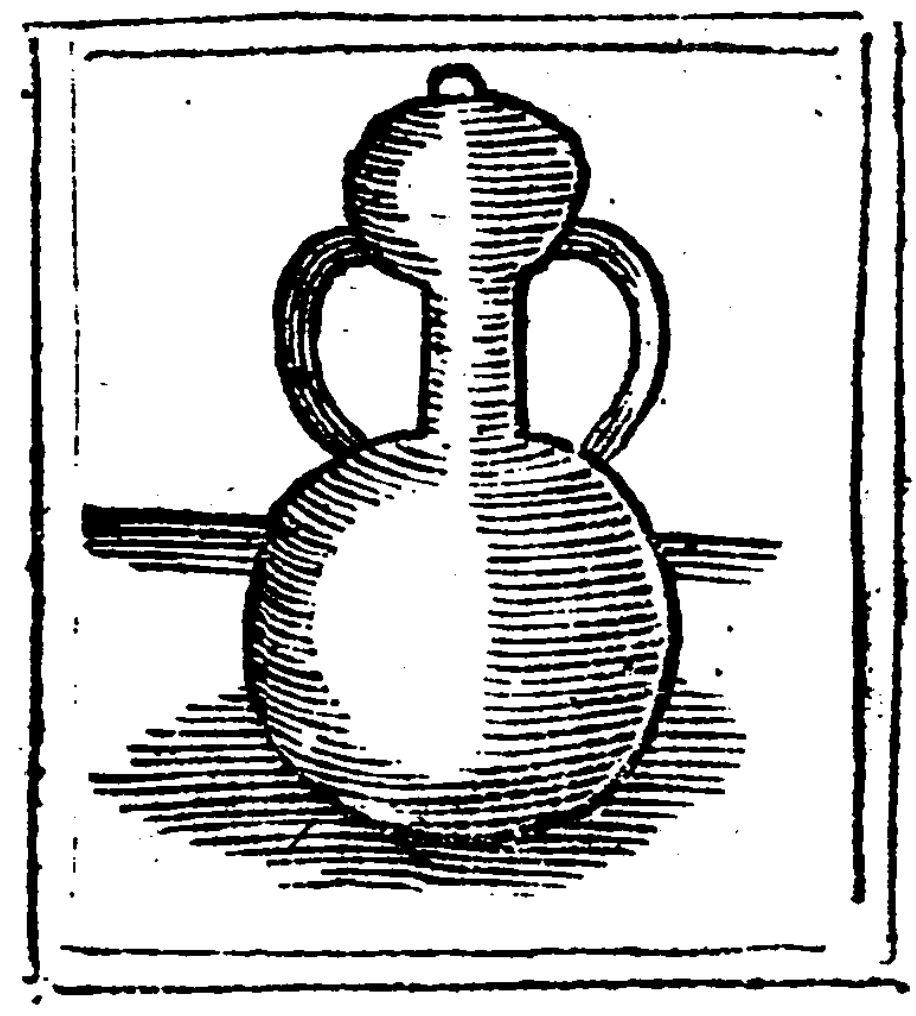

Source: John French, The Art of Distillation (1651).

Lady Mildmay seems to have had a positive relationship with the medical profession. As previously discussed, she was acquainted with the oculist and physician

\footnotetext{
${ }^{41}$ Pollock, With Faith, 130, 134-5.

${ }^{42}$ Charles Webster, ed., Health, Medicine and Mortality in the Sixteenth Century (Cambridge: Cambridge University Press, 1979): 326; Allen G. Debus, "The Paracelsians and the Chemists: the Chemical Dilemma in Renaissance Medicine" in Chemistry, Alchemy and the New Philosophy, 1550-1700 (London: Variorum Reprints, 1987): II.187. See Richard Bostocke, The difference between the auncient phisicke... and the latter phisicke (London, 1585).
} 
Richard Banister, who thought highly of Grace's methods. Her papers on diseases and regimens include nine courses approved by five different men. Two epilepsy treatments for the young have been attributed to a Mr. Waters, who also offered a course for melancholy, two more come from Doctor Athill, and another doctor, Poe, was the source of treatments for headaches and facial infirmities. Mr. Napper provided a single cure for palsy, and Mr. Langham is credited with a course for melancholy. ${ }^{43}$ We can surmise that she sought the advice of these physicians or surgeons when treating her own patients, adding their recommendations to her papers for future reference. These men, too, provided links to the chymical world. One of Athill's treatments included a cordial that called for "6 leaves of fine gold”, and Napper's drink for palsy required infusion in a balneum marie. $^{44}$ Master Waters took astrological influences into account, advising epilepsy sufferers to watch their diet and exposure to dampness "about the conjunction or change of the moon and likewise at the full". ${ }^{45}$ Like Grace, her male counterparts evidently chose not to limit their healing methods to a simple dichotomy wherein the Galenic and Paracelsian systems were mutually exclusive. They took a utilitarian approach to medicine rather than acquiescing to the status quo.

Lady Grace's papers include several references to printed chymical works, which indicate that these publications were not merely a part of her library but texts she had actively perused and sought to understand. She read widely on medicine, surgery and even chymistry. The first two mentions of external works come in the course for melancholy provided by Mr. Waters, which cites "Da Monte" and the medieval Persian polymath Avicenna. ${ }^{46}$ The former almost certainly refers to Italian humanist physician Giovanni Battista Monte, father of clinical medicine and professor at the University of Padua in the

\footnotetext{
${ }^{43}$ Poe may have been Leonard Poe, who in 1596 was granted a restricted license from the Royal College of Physicians in London. See RCP Munk's Roll, "Leonard Poe," online edn. [http://munksroll.rcplondon.ac.uk/Biography/Details/3595].

${ }^{44}$ Pollock, With Faith, 114.

${ }^{45}$ Ibid., 113.

${ }^{46}$ Ibid., 122-3.
} 
mid-1500s. Montanus, as he was sometimes known, publicized the Paracelsian conviction that a figure named "Elias artista" — associated with the Biblical Elijah — would reveal the secrets of nature to mankind just prior to the end of the world. ${ }^{47}$ Such eschatological concerns complemented the practice of medicine. In his instructions, Waters referred to a powder prepared by Montanus and a syrup attributed to Avicenna but did not provide details on either. It seems he assumed that Grace either possessed this knowledge already or could easily obtain it. Of course, we do not know how Waters's recipes were conveyed to Grace, whether the two communicated directly or were even acquainted. But the absence of additional notes on the powder or Avicenna's syrup in her transcription suggests that she did not view the lack of detail as problematic.

The next two chymical references are more decidedly Grace's own. The first, in her "preparation of pearls", suggests that any readers with ethical qualms about this receipt should "read an author called Arnaldus de Villanova in the book De retardanda senectute". ${ }^{48}$ Villanova, a thirteenth-century chymist and apocalyptic thinker, translated, among other works, writings by Avicenna, and a variety of original works have been attributed to him. The above-referenced text focused on the preservation of youth. In contrast, Grace's preparation was designed to comfort and clarify the heart, spirits and back. Her introduction of a seemingly unrelated work implies that there is more to this recipe than may be immediately apparent, perhaps recalling the tradition of deliberately obscure language in chymical texts. It follows and precedes other distinctly iatrochemical remedies. Creation of the pearl salt required great precision and, furthermore, Grace claimed, it could only be stored in a container made of silver or ivory.

Lady Mildmay evoked Paracelsus himself in her final mention of an external text. The versatile flowers of antimony could be used to cure tertian and quartan agues, ulcers

\footnotetext{
${ }^{47}$ Herbert Breger, "Elias Artista" in Nineteen Eighty-Four: Science Between Utopia and Dystopia, eds. Everett Mendelsohn and Helga Noworthy (New York: D. Riedel Publishing, 1984): 56.

${ }^{48}$ Pollock, With Faith, 133.
} 
when combined with ointment, and even healed fistulas. However, she noted, "it requireth a great while to make them in that perfection that Paracelsus hath set down in his book of surgery". ${ }^{49}$ This statement indicates not only that Grace had tested these instructions and learned how much time and effort they required, but also that she possessed sufficient expertise in this field to discern degrees of "perfection". It also suggests a firsthand familiarity with Paracelsus and at least one of his writings, the 1536 surgical publication Die grosse Wundarznei, which Lady Mildmay might have obtained as a manuscript translation. ${ }^{50}$ But this reference constitutes more than a statement of awareness of a controversial man and his system of medicine; she evidently felt no guilt or turmoil about including his name or a variety of iatrochemical remedies in the papers that she bequeathed to her daughter, finding value instead in the health they offered to her patients. Because Grace was devout and believed the contents of her mind to be the best gift she could offer her descendents, we can assume that she perceived no contradiction between her experiences with faith and medicine. It seems that Paracelsian medicine was practiced neither in opposition to its Galenic counterpart nor at the expense of spiritual convictions. Rather, the relationship was much more complex. Paracelsus combined his faith and medical forays into a cohesive and coherent set of beliefs, and it appears that Lady Mildmay did the same.

Grace's faith clearly shaped her medical practice. She perceived illness to be the direct result of mankind's fall from grace, an affliction that has been "hanging over man's head since he let in sickness by sin". ${ }^{51}$ Accordingly, her cures work to eliminate perceived evil. Midway through preparation, the oil of antimony forms a reddish oil "and a sulphury water with an evil savour", a strong statement from a woman who would be unlikely to use

\footnotetext{
${ }^{49}$ Ibid., 134.

${ }^{50}$ I have not found evidence of a printed English translation of this particular work during Lady Mildmay's lifetime. However, Latin and French editions were produced, and it is likely that an English version circulated in manuscript format.

${ }^{51}$ Pollock, With Faith, 111.
} 
the word lightly. ${ }^{52}$ Grace's perception of health was animated by the very principles and ideas contained in the Bible. It is hardly surprising that she sought (and found) the same when she directed her gaze upon the other divine book, that of nature. She interpreted the work performed by her cure for epilepsy as follows: "For the balm oil and the parts working together in continuance of time, maketh nature strong to retain the good and to cast out the evil, which else would overcome nature". ${ }^{33}$ By practicing medicine, Grace believed she had aligned herself with the good in the fight against this evil, which otherwise might prevail. As we will see, her healing experiences affected the way that she wrote about her religious beliefs.

Her medical papers offer vivid impressions of their author's personality. Thorough in receipt-writing and record-keeping, Grace offered strong expressions of opinion throughout. For instance, we learn that bleeding was not her preferred course of treatment for mental illnesses such as frenzy: "To rely most on bloodletting to cure these diseases turneth them into sottishness". ${ }^{54}$ She also openly disdained a rather invasive guiacum treatment for female reproductive problems, claiming that she took "this medicine to be very dangerous and evil to be applied unto women in this manner". 55 Though Lady Mildmay included the instructions for making this oil, she ended the entry on an equally pessimistic note, asserting, "I have no experience of this order of diet but I prefer many other before it". ${ }^{56}$ In these papers we glimpse a woman comfortable enough with her own experience as a healer to determine right from wrong and situate herself on the side of the former.

\footnotetext{
52 Ibid., 134.

${ }^{53}$ Ibid., 113.

${ }^{54}$ Ibid., 119.

${ }^{55}$ Ibid., 135.

${ }^{56}$ Ibid., 136.
} 
By healing those around her, Grace combated sin and its manifestations in a divinely sanctioned way. Her autobiography indicates her keen awareness of temptation from a young age: "I spent the best part of my youth in solitariness, shunning all opportunities to run into company least I might be enticed and drawn away by some evil suggestions to stain mine unspotted garment and so be robbed of mine innocency", presumably while her husband's travels took him far from their home. ${ }^{57}$ The image of Grace as unspotted and innocent recurs, and she framed any source of conflict as a heavensent test of her convictions. With this belief she took a page from her mother's book, operating on the assumption that "the minds of children are tainted and corrupted, even from their infancy" ${ }^{58}$ Because Lady Sharington believed "that by nature we are inclined rather to learn and retain the evil than the good", she laid before her daughters only a quartet of books to set them on the path of goodness: the Bible, Musculus's Common Places of Christian Religion, Foxe's Book of Martyrs and, unusually, a Catholic meditation, Thomas à Kempis's The Imitation of Christ, which surely informed Grace's adoration of Christ — and her steadfast response to the many afflictions she suffered. ${ }^{59}$

While she displayed no shortage of faith in the divine, her education and experiences led her to be less optimistic with respect to human nature and, indeed, this life. "I have learned", she wrote, "to put no confidence in man nor in any child of man, nor in any earthly things which are all changeable and uncertain and there is no truth in them". ${ }^{\circ}$ Anthony and Grace often struggled financially, a plight not helped by complications with the wills of their parents and unanticipated avarice from their siblings. Grace appears to have viewed these difficulties as merely another example of the necessary trials she had to endure. Conversely, any crisis averted signaled divine favor. "There was never any thing more blessed unto me in this life than mine afflictions and trials which were never greater

\footnotetext{
${ }^{57}$ Ibid., 34.

${ }^{58}$ Ibid., 25.

${ }^{59}$ Ibid., 28.

${ }^{60}$ Ibid., 39.
} 
than God enabled me to bear". ${ }^{61}$ Grace's emphasis on the next life makes sense in the context of the first prayer she ever learned from her mother: "that I should beg of God a blessed end and departure out of this life". ${ }^{62}$ Because this life is merely the prelude to a greater purpose, she could minimize the pain and suffering she experienced and focus instead on her own strength in surviving these trials. If her self-fashioning is to be believed, she kept her gaze fixed firmly on heaven from birth until death.

Lady Mildmay's emphasis on human sin and the next life provides another link to the chymical world. As discussed in Chapter 1, famed chymists like the iconoclast Paracelsus and Johannes of Rupescissa shared her preoccupation with this merging of the earthly and terrestrial spheres that would mark the End Times. The Reformation and the resulting religious conflict as well as widespread disease convinced many that they were living at a momentous point in time, effectively "the beginning of the end". ${ }^{63}$ Paracelsus prophesied that "Helias" or "Elias Artista", identified with the Biblical prophet Elijah, would reveal nature's hidden secrets as a prelude to the renovatio Joachim of Fiore had forecast. ${ }^{64}$ Elijah, now symbolically portrayed as a chymist, would arrive after Paracelsus's death to usher in the Messianic Age of Gold with his transmutatory powers.

The writings of Calvinist clergyman Thomas Tymme illustrate the spread of chymical eschatology in England during the latter part of Elizabeth's reign. ${ }^{65}$ The author of a number of prophetic and apocalyptic texts from 1586 onward, Tymme's focus shifted to natural philosophy at the start of the sixteenth century. He translated chymical works by Joseph Du Chesne and John Dee and in 1612 wrote an original work, A dialogue

\footnotetext{
61 Ibid.

${ }^{62}$ Ibid., 29.

${ }^{63}$ Webster, Paracelsus, 210-43. See also Leah DeVun, Prophecy, Alchemy, and the End of Time: John of Rupescissa in the Late Middle Ages (New York: Columbia University Press, 2009).

${ }^{64}$ William R. Newman, Gehennical Fire: The Lives of George Starkey, An American Alchemist in the Scientific Revolution (Cambridge: Harvard University Press, 1994): 3-4.

${ }^{65}$ See Bruce Janacek, "Thomas Tymme and Natural Philosophy: Prophecy, Alchemical Theology, and the Book of Nature" in Sixteenth Century Journal, Vol. 30, No. 4 (1999): 987-1007.
} 
philosophicall. Wherein natures secret closet is opened. ${ }^{66}$ As Bruce Janacek has shown, this progression indicates a relationship between eschatological concerns and chymical pursuits. Like Paracelsus, Tymme viewed the chymical opus as a "redemptive process for the fallen natural world" whereby it could be restored to its former divine, sinless glory. ${ }^{67}$ This perspective may have informed Grace's own iatrochemical activities, further reinforcing the link between her spiritual beliefs and charitable healing that she so clearly articulated:

this anchor of our hope should not decay in us, nor fail us, the precious box of balm and sweet ointment was broken when Christ was crucified upon the cross and poured out upon us from all his blessed parts, that every one of us might receive the sweetness and fruitfulness thereof and be encouraged and strengthened in his holdfast, never to give over until the end. ${ }^{68}$

In the crucifixion Grace envisioned a universal medicine soothing each person's sins until the End Times. She thus equated Christ's redemptive aspect with the philosopher's stone, echoing a point John Dee made in his Monas Hieroglyphica. The cross's four lines met at the center, he observed, representing the union of the four elements and the creation of the fifth: the sacred quintessence, itself associated with the stone. ${ }^{69}$ For chymists, like Christians, the cross simultaneously symbolized sacrifice and the unified state it produced: the Messianic Age of Gold. ${ }^{70}$ The interconnectedness of iatrochemistry and spirituality manifests in Grace's meditations.

Chymistry clearly influenced the very beliefs that prompted Lady Grace to practice medicine in the first place. Of the 912 folios that she filled with her spiritual meditations, only a representative selection of approximately ten percent has been published. ${ }^{71}$ Grace repeatedly emphasized Christ's role as the resurrection and the life, and the assurance that

\footnotetext{
${ }^{66}$ See Thomas Tymme, A dialogue philosophical. Wherein natures secret closet is opened (London, 1612).

${ }^{67}$ Janacek, "Thomas Tymme," 990.

${ }^{68}$ Pollock, With Faith, 88.

${ }^{69}$ C.H. Josten, “A Translation of John Dee's 'Monas Hieroglyphica' (Antwerp, 1564), with an Introduction and Annotations" in Ambix, Vol. 12, Nos. 2/3 (1964): 159.

${ }^{70}$ Abraham, Dictionary, 49.

${ }^{71}$ Pollock, With Faith, 2.
} 
God would never abandon the faithful. ${ }^{72}$ My research expands upon the connection Jennifer Wynne Hellwarth drew between Lady Grace's religious beliefs and her perception and practice of medicine. ${ }^{73}$ By acknowledging the profusion of medical and specifically chymical imagery in these meditations, I shed light on the way Mildmay synthesized her spiritual views and the chymical concepts she put into practice.

Biblical images of cleansing and healing waters bring medicine to mind throughout Grace's meditations. Like other devoted Protestants, she viewed physical illness as a symptom of spiritual impediments. ${ }^{74}$ Grace naturally looked to Christ as both healer and the image of living waters, signifying eternal life. She addressed him, variously, as "fountain of the gardens" and "well of living waters and springs of Lebanon", praying for him to "[w] ash and plunge me in that blessed fountain of thy precious blood which thou hast shed for me, whereby I may be made wholly clean and acceptable unto thee and meet for thy holy service". ${ }^{75}$ More than direct links to her daily biblical readings, these metaphors had a practical basis; for a woman who prepared herbal and chymical medicines on a large, systematic scale, Christ's healing waters nurtured the very ingredients she required. For chymists, the fountain or aqua permanens had transformative, generative powers. ${ }^{76}$ Grace's meditations echo The Dialogue of Cleopatra and the Philosophers, a second-century CE chymical text emphasizing the unity of all things and birth, death and rebirth courtesy of "divine" or "blessed waters", also described as the "medicine of Life". 77 Grace reinforced this notion with her meditation on the first psalm:

if my whole delight and continual exercises be in the law of the Lord, then shall I be like a tree planted by the water's side, that will bring forth her fruit in due season. Even the plant of the Lord which shall be continually refreshed by God himself who is the fountain of living waters. And my leaf

\footnotetext{
${ }^{72}$ Pollock, "Lady Grace Mildmay," $O D N B$.

${ }^{73}$ See Jennifer Wynne Hellwarth, “'Be unto me as a precious ointment': Lady Grace Mildmay, SixteenthCentury Female Practitioner" in DYNAMIS, Acta Hispanica ad Medicinae Scientiarumque Historiam Illustrandam, Vol. 19 (1999): 95-117.

${ }^{74}$ Ibid., 96. See Margaret Hoby, Chapter 4, for a similar viewpoint.

${ }^{75}$ Pollock, With Faith, 74, 83. Grace was alluding to John 4:7-26 and Song of Solomon 4:15.

${ }^{76}$ Abraham, Dictionary, 81.

${ }^{77}$ F. Sherwood Taylor, The Alchemists (London: Scientific Book Club, 1950): 57-9.
} 
shall not wither but look whatsoever I do it shall prosper. And, in as much as my work shall be always the Lord's, my labour shall not be in vain in the Lord. $^{78}$

She clearly saw a direct causal relationship between her faith, the healing properties of the divine and the medicaments she produced to assist those in need. Her work, of course, was not solely her own — she healed as a representative of God.

The meditations also include explicit references to the divine role in medicine. In one of her more sensuous entries, Grace exhorted her "welbeloved" to "indue me with his love, and with the savour of his good ointments. Let his holy name be unto me as a precious ointment poured out", thus transforming the very act of prayer into a healing prescription from the holiest of physicians. ${ }^{79}$ Fittingly, she went on to address Christ not only as her savior, father, friend and brother, but also as " $[\mathrm{m}] \mathrm{y}$ dear husband, my dear master, doctor and teacher". ${ }^{80}$ In addition to his role as divine healer, he also taught her (through printed manuals, manuscript receipt books and the advice of the learned) to achieve the same end. Furthermore, as Hellwarth has observed, Lady Mildmay embedded evidence of her familiarity with Galenic and Hippocratic humoral theory in her meditations, emphasizing the importance of balance through the application of opposites when she wrote that "the worth and operation of all the bleeding wounds of our saviour Jesus Christ issued forth, unto us, the sap of life, even the most pure and precious balm wherewith we are embalmed and thoroughly healed". ${ }^{81}$ This phrasing recalls the "most precious and excellent balm" of her medical papers, recognizing in Christ the ultimate polychrest or panacea. For Grace, the purging of Christ's sacrificial blood thus purified humanity in an act reminiscent of bloodletting. ${ }^{82}$

\footnotetext{
${ }^{78}$ Pollock, With Faith, 82.

${ }^{79}$ Ibid., 75. See Song of Solomon 1:3.

${ }^{80}$ Ibid., 75.

${ }^{81}$ Ibid., 77.

${ }^{82}$ Hellwarth, "Lady Grace Mildmay," 112-3.
} 
Lady Mildmay's meditations provide a solid spiritual defense of the practice of medicine. In her enumeration of the infinite variety in God's creation, she detected healing potential, the possibility of doing good in God's name. She listed "plants, trees, fruits, spices, precious balms natural, natural baths which boil like a furnace, ordained for health. All sorts of precious gums for medicine, sweet odours, gold, silver, pearl, precious stones". ${ }^{83}$ She used many of these items in her medical practice, and her childhood readings of William Turner's Herball would have exposed her to the virtues of natural baths. ${ }^{84}$ Her carefully selected list was designed to remind us of "the mighty power of God and his love unto man. And especially (which is above them all) that God hath given man wisdom and knowledge to use them and to avoid the abuse of them and to make choice betwixt the good and the evil of them". ${ }^{85}$ In addition to placing God's creation in the context of its ability to heal, Lady Grace thus created a sense of obligation on the part of mankind. Granted the wisdom to discern good from evil, it is our responsibility to make the correct decision. Even after a lapse in judgment in the Garden of Eden, humanity, though fallen, has the ability to improve our postlapsarian state. For Grace, like Paracelsus and Thomas Tymme, that resolution involved using the herbs and chymical substances she had readily available to produce medicines and help those in need. Implicit in this statement seems to be an acknowledgment of the danger inherent in practicing medicine the same risk we will witness early in Margaret Hoby's diary, when her physician perishes after self-administering what he believed to be a cure. Grace may also be defending her healing skills. Her self-proclaimed familiarity with herbals and surgical texts ensures that she would have been aware of criticisms slung at a variety of non-traditional practitioners.

These rather sweeping references to healing are interspersed with more direct evidence of Grace's engagement with the chymical community. Though her chymistry

\footnotetext{
${ }^{83}$ Pollock, With Faith, 84.

${ }^{84}$ See William Turner, The seconde part of VVilliam Turners herbal...Herevnto is ioyned also a booke of the bath of Baeth in Englande, and of the vertues of the same (London, 1562).

${ }^{85}$ Pollock, With Faith, 84.
} 
had a utilitarian basis, for Lady Mildmay, like many other practitioners, it was imbued with spiritual significance. A woman who engaged with biblical and religious texts so directly and thoroughly would naturally approach other readings in the same manner. Thus we find a meditation titled "By examination a man seeth himself whether he be gold or copper", applying the chymical hierarchy of the perfection of metals to the souls of men. ${ }^{86}$ Similarly we learn that, for Grace, the holy gospel was "a powerful word and worketh divers effects and operations", recalling the complex chymical process. ${ }^{87}$ Like the philosopher's stone, the gospel is at once many things, indescribable; she compared it to a sword, fire, a hammer, a seed, dew, David's sling, a pearl, a draw net, the leaven from which we are shaped, many of these imbued with chymical significance. ${ }^{88}$

By transmuting the raw materials of God's creation into medicine, Grace helped purge herself, her patients and the earthly world of sin. Lady Mildmay's assessment of her "loathsome heart" as "a very sink of sins" is the most definitive amalgam of chymical and spiritual insights revealed in her meditations:

Yet as God hath ordained fire to refine gold and as wines poured from vessel to vessel are purified, so hath he ordained means to refine and purge this heart from all her dross, lees, dregs and scum and from her old leaven of malice and wickedness. And to make it a clean vessel, more pure than the gold and to retain the holy spirit of God and the light of his heavenly graces which his holy sacrament infallible bringeth unto us. ${ }^{89}$

Here Lady Mildmay located her faith in the divine amidst a veritable treasure trove of chymical images. The twin notions of refining gold with a cycle of dissolution and coagulation (solve et coagula) — a trial by fire — and purifying liquids through distillation (distillatio) align this spiritual cleansing with the chymical process. ${ }^{90}$ Gold representing the most perfect of the metals in God's creation, to be "more pure than the gold" implies

\footnotetext{
${ }^{86}$ Ibid., 80 .

${ }^{87}$ Ibid., 84.

${ }^{88}$ On the philosopher's stone's many names, see Abraham, Dictionary, 147. See also fire (76-7), seed (180), dew (53-4) and pearls (142-3).

${ }^{89}$ Pollock, With Faith, 77.

${ }^{90}$ Abraham, Dictionary, 55-6, 169-70.
} 
divinity itself. Indeed, chymists held that only gold could retain its true nature when subjected to the refining fire. According to this meditation, the souls and hearts of mankind form the prima materia upon which God performs the various stages of the chymical opus. Grace thus translated the chymical texts she read into the language of spirituality.

An additional meditation may benefit from chymical elucidation. In a reference to Isaiah 28:9, Grace prayed, "Let me be weaned from thy milk and drawn from the breasts that thou mayest teach me knowledge". ${ }^{91}$ Her phrasing very nearly echoes that of the biblical passage, which, like Lady Sharington, holds that knowledge of the divine should begin early: "Whome shall he teache knowledge? ...them that are weyned from the milke, and drawen from the breastes". ${ }^{92}$ Rather than modifying "milke" with a definite article as in Isaiah, however, Grace attributed possession with "thy", transforming that life-giving milk into an aspect of the divine. As this supposition hinges on a single word, I acknowledge the possibility that there may have been an error in transcription, or that Lady Mildmay misremembered the passage. However, given the familiarity with chymical writings that her medical papers indicate, she may well have embraced the symbolism that so effectively combined her faith and practice. The result is a decidedly feminine image of Christ as nurturing, breast-feeding mother to humanity, in keeping with the healing capabilities of the "fountain of the gardens". A devout woman like Lady Grace may have used such a metaphor in order to discern how her gender fit in to the notion that man was created in God's image. In this meditation she described a transitional state: from that of sustenance through divine milk to growth through knowledge, also from the divine, which we know she embraced from childhood in the form of readings suggested by Mrs. Hamblyn. Her charitable medical practice resulted.

\footnotetext{
${ }^{91}$ Pollock, With Faith, 78.

92 Taken from the Geneva Bible (1587).
} 
Such hermaphroditic imagery would be familiar to anyone acquainted with

Plato's Symposium or the tale of Hermaphroditus and Salmacis in Ovid's Metamorphoses. It also has precedent in both religious iconography and alchemical emblems. ${ }^{93}$ During the medieval period alchemists began to associate the philosopher's stone with hermaphroditism. With the creation of the early fifteenth-century Aurora consurgens, filled with self-consciously Christian symbolism, the image of the hermaphrodite transformed from that of an object or plant to a human. ${ }^{94}$ The Aurora depicts an ostensibly female figure, Sapientia (Wisdom), with undeniably masculine characteristics: "I will yet be as a father to him". 95 Furthermore, in this text Christ was equated with the lapis (stone). Leah DeVun cites a contemporaneous manuscript, the Book of the Holy Trinity, which claimed that " $[\mathrm{t}]$ he humanity of bright Mary was the interior and exterior humanity of God Jesus Christ all made together; he had not and has no other humanity...thus Jesus-Mary is and was one being in the same substance". ${ }^{96}$ Such an assertion harmonized with feminized accounts of the divine that sprung up during the late Middle Ages. ${ }^{97}$ Christ, then, was the ultimate hermaphrodite by virtue of the unification of contrary parts (son and mother, human and divine, male and female, gendered and genderless) he constituted. Grace's description of the divine in this meditation represents a continuation of these traditions that encompass two intertwining and significant aspects of her life.

That Lady Grace Mildmay engaged with the chymical world through charitable healing is clear. Her extensive medical papers, autobiographical account, and the imagery in her meditations demonstrate this beyond question. From childhood she learned to stave

\footnotetext{
${ }^{93}$ See Abraham, Dictionary, pp. 98-9.

${ }^{94}$ The earliest known edition of the Aurora was produced in the $1420 \mathrm{~s}$ and is now housed at the Zentralbibliothek in Zurich (Codex Rhenoviensis 172). See Leah DeVun, "The Jesus Hermaphrodite: Science and Sex Difference in Premodern Europe" in Journal of the History of Ideas, Vol. 69, No. 2 (2008): 193-218.

${ }^{95}$ Marie Louise von Franz, ed., Aurora consurgens, (London: Routledge \& Kegan Paul, 1966): 58.

${ }^{96}$ DeVun, "Jesus Hermaphrodite," 209-210.

${ }^{97}$ See Bernard of Clairvaux, Aelred of Rielvaux, William of St. Thierry, Elizabeth of Schönau and Julian of Norwich.
} 
off idleness with healing words, whether biblical or medicinal, and as an adult she put this knowledge into practice. Her writings defy the simple categorization of medical practitioners along strict lines. Though forbidden from undertaking a university education, she adhered to principles not far removed from those of a member of London's Royal College of Physicians. Grace treated physical and mental conditions alike, targeting both acute symptoms and long-term conditions. She employed scholastic or humanist elements from the Galenic system alongside more traditional herbal folk remedies and, significantly for us, iatrochemical cures. The latter medicaments were not officially sanctioned by the College of Physicians until shortly before Mildmay’s death, in $1618 .^{98}$ In a sense Lady Grace was ahead of her time - or at least ahead of the College's attempts to institutionalize and control the practice of medicine.

Lady Mildmay furthermore provides an example of the heterogeneity of medical practitioners during Elizabeth's reign, her papers at once singular and characteristic of the variety available to sufferers during the second half of the sixteenth century. The number of physicians was insufficient to treat those who were ill, particularly in rural areas, and it has been well documented that the majority of the sick would have been unable to afford their local doctor's services. ${ }^{99}$ Many turned to empirics, cunning folk and charitable practices of gentlewomen like Lady Grace. Because her interactions with the court were secondhand, Mildmay's exposure to iatrochemistry and Paracelsian texts is of particular interest. We can only speculate as to the source of this information - Mistress Hamblyn, the physicians with whom she was acquainted, family members, friends or her own desire to forestall inactivity with new reading material and knowledge — but, like the other subjects of this study, she perceived no conflict between chymistry and her profound piety. Rather, she followed Paracelsus in discerning and developing links between the two,

\footnotetext{
${ }^{98}$ Brian Nance, "Sir Matthew Lister (bap. 1571, d. 1656)", $O D N B$, online edn. [http://www.oxforddnb.com/view/article/16764, accessed 6 May 2010].

${ }_{99}$ See, for instance, Margaret Pelling and Charles Webster, "Medical practitioners," 165-235.
} 
transmuting eschatological concerns into active pursuit of renewal and regeneration. Over time these aspects of her life became inextricably interconnected, representing parallel methods for achieving the same goal: performing God's work. 


\section{Chapter 3}

\section{Noble Nurse of Learning: Mary Sidney Herbert}

Echoing Queen Elizabeth, Mary Sidney Herbert (1561-1621) engaged with the chymical world as muse, patron and practitioner by presiding over a microcosmic court at Wilton House. She established her own chymical laboratory and inspired creativity in those around her. Furthermore, Lady Mary, the countess of Pembroke, managed to do what the vast majority of aristocratic women in her time could not: express herself in print without a loss of status. ${ }^{1}$ While much has been made of her literary achievements, particularly as they related to her late brother Philip Sidney, this research addresses those works only insofar as they reflect her chymical expertise. By identifying with Philip and celebrating his memory, she ensured that her own reputation would endure and, in a sense, stepped outside of the boundaries that confined early modern Englishwomen. Together these siblings with shared chymical interests recalled the self-regenerating chymical phoenix, emerging triumphantly from its own ashes.

A member of the influential Sidney, Herbert and Dudley clans, Mary Sidney Herbert knew the queen from a young age. She also had close ties to other chymically proficient gentlewomen. ${ }^{2}$ Margaret Dakins Hoby married her brother, Thomas Sidney, though his death cut short their relationship, and Margaret Clifford's daughter Anne would later marry Philip Herbert, Lady Mary's younger son. These two women will be discussed in Chapters 4 and 5, respectively. That gentlewomen rather than the lower classes left behind a preponderance of manuscript receipt books and other evidence of their interest in chymistry comes as no surprise, but the connections between these ladies are significant.

\footnotetext{
${ }^{1}$ On female writers and the challenges they faced, see Elaine V. Beilin, Redeeming Eve: Women Writers of the English Renaissance (Princeton: Princeton University Press, 1990).

${ }^{2}$ Her chymical links extended beyond the scope of this thesis into the Stuart period. Mary Talbot, the wife of her eldest son, had two chymically inclined sisters: Elizabeth Grey and Aletheia Howard, the latter of whom published a variety of recipes in Natura Exenterata (1655).
} 
On a practical level, a child raised in a household acquainted with chymistry is far more likely to carry on those activities in adulthood than a child unfamiliar with the subject. In the former instance, chymistry simply constitutes another thread in the fabric from which everyday life is woven.

Lady Mary's life testifies to the importance of community for chymical practitioners. While posthumously praising her knowledge of chymistry, biographer John Aubrey connected the countess to three different men. After examining what they tell us about Mary's practice, I explore precedents for her engagement with the chymical world, highlighting significant connections between her family and John Dee. Next I turn to Lady Mary's own life as context for the chymical court she established at Wilton House, her Wiltshire home. Here she underwent a bereavement process of seclusion and regeneration after losing her father, mother and beloved brother Philip. The writings that Mary produced on her own and in conjunction with Philip adapted chymical symbolism for literary and spiritual purposes. We find similar symbolic language when examining how her contemporaries represented the countess. Lady Mary's reputation for learning, like that of the queen, implicitly pointed to knowledge of the natural world. Much of what we know about her chymical associations comes to us second- or even thirdhand. There is a danger in making suppositions on the basis of unverifiable claims; however, those claims are well worth exploring.

Biographer and antiquarian John Aubrey (1626-1697) included Lady Mary among the luminaries in his Brief Lives, though the two never met; he was born five years after her death. His biographical sketch includes an assessment of one of her lesser-known hobbies:

She was a great Chymist, and spent yearly a great deale in that study. She kept for her Laborator in the house Adrian Gilbert (vulgarly called Dr Gilbert) halfe-brother to Sir Walter Raleigh, who was a great Chymist in those dayes and a Man of excellent naturall Parts... She also gave an honourable yearly Pension to Dr. Mouffet, who hath writt a Booke De 
Insectis. Also one Boston, a good Chymist, a Salisbury man borne, who did undoe himselfe by studying the Philosophers-stone, and she would have kept him, but he would have all the golde to himselfe, and so dyed, I thinke, in a Gaole. ${ }^{3}$

Despite Aubrey's weakness for unsubstantiated gossip, he adopted a matter-of-fact tone when discussing the countess's aptitude for chymistry. We find neither condemnation of her scientific pursuits nor any indication that he deemed them inappropriate for a woman. On the contrary, his words imply that Lady Mary's chymical skills were widely known and praised. The three men he associated with the countess - Adrian Gilbert, Thomas Moffet and "Boston" - suggest that she took a diverse approach to chymistry.

Little is known of the man "Boston" beyond what Aubrey wrote, but this account may have been based on a real person. His hometown of Salisbury indicates that he was a local with social connections to the Pembrokes. Aubrey's description of Boston also serves to broaden our impression of Lady Mary's chymical activities. The ill-fated man's pursuit of the philosopher's stone apparently did not deter her patronage; his own greed imprisoned him, while the countess willingly supported his goal of chrysopoeia.

Lady Mary also patronized Thomas Moffet (1553-1604), her doctor, who combined chymistry and literary talents. Prior to matriculating at Cambridge, where he gained a solid foundation in both classics and medicine, Moffet studied at Merchant Taylors' School alongside Edmund Spenser. ${ }^{4}$ He subsequently attended medical school in Basel under Theodore Zwinger, boarding with the chief physician, Felix Platter, who introduced Moffet to the Paracelsian medical theory he would embrace. Indeed, his doctoral thesis attacked Thomas Erastus, a strident opponent of chymical medicine. He was only awarded the MD on the basis of a censored version in 1579. Before returning to England the following year, he befriended Lady Mary’s brother Robert in Strasbourg, established a

\footnotetext{
${ }^{3}$ John Aubrey, Brief Lives, ed. Oliver Lawson Dick (Boston: David R. Godine, 1999): 139. This work was compiled between 1669 and 1696. See Adam Fox, "John Aubrey (1626-1697)," ODNB, online edn. [http://www.oxforddnb.com/view/article/886, accessed 2 October 2010].

${ }^{4}$ Thomas Moffet, Nobilis or A View of the Life and Death of a Sidney and Lessus Lugubris, eds. Virgil B. Heltzel and Hoyt H. Hudson (San Marino: Huntington Library, 1940): xiv.
} 
medical practice in Frankfurt and studied silkworm culture in Italy. ${ }^{5}$ In the summer of 1582 Moffet traveled to Denmark as the personal physician of Peregrine Bertie, Lord Willoughby, whose chymical interests I will discuss at length in Chapter 5. There he met with astronomer Tycho Brahe and Petrus Severinus, an influential Paracelsian. ${ }^{6} \mathrm{He}$ subsequently dedicated medical works to both Severinus and Willoughby in 1584 and 1588. The former challenged the Royal College of Physicians to recognize the utility of Paracelsian medicine despite conflicts with Galenism. The fact that Moffet not only became a Fellow of the College but in 1588 was elected Censor indicates the degree to which English medical practitioners began to accept Paracelsian techniques in the final decades of the sixteenth century. The following year he helped compile the College's official Pharmacopoeia Londinensis, to which he contributed chymical medicines. ${ }^{7}$ The volume would not be completed until 1618, suggesting that not everyone favored the inclusion of Paracelsian remedies. Among those Moffet treated in his homeland were Philip Sidney, Francis Walsingham and the Pembrokes, who employed him until his death in 1604.

Lady Mary's association with Moffet in Aubrey's account indicates that she, too, may have harnessed chymical knowledge for medicinal purposes in keeping with the encouragement of charity among gentlewomen. As we saw with Grace Mildmay, they frequently offered medical advice and cures to the sick and poor in their area. Because these services were provided free of charge to people who could not afford a physician's fees, ladies maintained good relations with their local doctors; they were not in direct competition. Aubrey also noted that Lady Mary’s son Philip Herbert’s “chiefest Diversion was Chymistrie, which his Lordship did understand very well and he made Medicines, that

\footnotetext{
${ }^{5}$ Victor Houliston, "Thomas Moffet (1553-1604)," ODNB, online edn. [http://www.oxforddnb.com/view/article/18877, accessed 8 August 2010]. ${ }^{6}$ Moffet, Nobilis, xiv-v.

${ }^{7}$ Houliston, "Thomas Moffet," ODNB; Allen G. Debus, The Chemical Philosophy: Paracelsian Science and Medicine in the Sixteenth Century (Mineola: Dover, 2002): 182-4.
} 
did great Cures". ${ }^{8}$ Perhaps this hobby developed after a childhood spent bearing witness to his mother's devotion to the subject and conducting his own experiments in her laboratory.

Manuscript evidence supports the countess's practice of iatrochemistry. Several cures linked to Mary's name survive in manuscripts at the Bodleian and British libraries. MS Ashmole 1481 includes an emetic recipe attributed to her. "My Lady of Pembrookes Vomett", designed to be drunk whilst fasting, appears alongside other practical remedies believed to comfort anyone suffering from a cough, sore eyes, worms, the stone and more. ${ }^{9}$ This recipe cites Mary Sidney Herbert's position rather than her given name; accordingly, it may refer to one of the other ladies who held that title, for instance, Anne Clifford, who took great pride in her mother's chymical abilities, as we shall see. She married Philip Herbert and became countess in 1630, prior to the composition of this manuscript in 1644. ${ }^{10}$ Lady Anne held additional titles and it seems unlikely that others would refer to her only by one acquired in later life. We find a more definitive reference to Lady Mary in Sloane MS 1988, which includes "Tragea Comitisse Pembrokia" alongside the writings of Thomas Moffet. ${ }^{11}$ This receipt bears marked similarities to a cordial water attributed to Adrian Gilbert, the third man connected to Mary's chymical practice. ${ }^{12}$ Aubrey’s assessment of his chymical skills may have stemmed from the circulation of recipes like this one.

Gilbert, who worked alongside Mary in her chymical laboratory, evidently also employed chymistry for medicinal purposes. His name appears in connection with at least

\footnotetext{
${ }^{8}$ Aubrey, Brief Lives, 146.

${ }^{9}$ Margaret P. Hannay, Philip's Phoenix: Mary Sidney, Countess of Pembroke (Oxford: Oxford University Press, 1990): 131.

${ }^{10}$ Richard T. Spence, “Anne Clifford (1590-1676)," ODNB, online edn.

[http://www.oxforddnb.com/view/article/5641, accessed 16 February 2010]. See BL on Sloane MS 1481: Paper, 12mo, ff. 95; XVII century; written partly in 1644. A collection of receipts in surgery, cookery, preserving, etc. ff. 1-95.

${ }^{11}$ See ibid., Sloane MS 1988: "Collectanea Medica D. Spicer a Mouffeto, Darnel, et Turnero", ff. 126-40; "Sequentia sunt Mouffeti a Darnello tradita", ff. 169-74; and "Praxis Mouffeti ex manuscripto codice magistri Parnely pharmacopoei ejusdem Mouffeti", ff. 184b-92.

${ }^{12}$ Hannay, Philip's Phoenix, 131. Gilbert's recipe is found in MS Ashmole 1499, f. 209v and MS Ashmole 1385 , f. 145 .
} 
one printed elixir in The Queens Closet Opened. "Dr. Adrian Gilberts most Sovereign Cordial water" requires a veritable garden of greens and blooms, ranging from familiar varieties of mint, sage and thyme to the less commonplace (and more toxic) pennyroyal, wormwood, "Dragon" and rossolis. He exhorted his readers to "steep all these in the lees of pure strong venient Claret Wine for nine dayes, every day twice turning them to mingle them well...then distill them in a Limbeck [alembic] with a red clear head, with two pound of shaved Harts horn, and Ivory twelve ounces". ${ }^{13}$ Something of a panacea, this cordial protects against the plague, ordinary and "spotted" fevers as well as pock marks. The comprehensive list of ingredients indicates that the men and women who produced these cures must have possessed large gardens, sufficient funds and worldly connections. Like many early modern recipes, the cure was made in bulk quantities, lessening the time, energy and expense each dose required. Such medicaments would have been particularly useful for physicians, empirics and gentlewomen who administered treatments on a larger scale.

Adrian Gilbert connects Mary Sidney Herbert to his teacher John Dee, a man her family knew well. Mathematician, navigator, astronomer and royal astrologer to the queen, Dee immersed himself in the study of chymistry, which contributed to his reputation as a magus even during his lifetime. His 1564 work Monas Hieroglyphica expresses the unity of all creation, a concept consistent with the chymical notion of the perfectibility of substances. ${ }^{14}$ Gold, for instance, is a more perfect form of silver, which in turn is a more perfect form of lead, and so on. Dee documented his interactions with Gilbert: in his diary, the Mysteriorum Libri V and, posthumously, in Meric Casaubon's $A$ True \& Faithful Relation of What Passed for Many Yeers between Dr. John Dee and Some Spirits, a 1655 publication that transcribed portions of MS Cotton Appendix XLVI, Dee’s

\footnotetext{
${ }^{13}$ W.M., The Queens Closet Opened (London, 1655): 11-2.

${ }^{14}$ See, for instance, F. Sherwood Taylor, The Alchemists (London: Scientific Book Club, ca. 1950): 3; and Peter J. French, John Dee; The World of an Elizabethan Magus (London: Routledge \& Kegan Paul, 1972): 76-83.
} 
account of his encounters with angels. ${ }^{15}$ The diary attests to their long-term association with nine references to Gilbert between October 1579 and January 1590. In early 1583 they were involved in an ultimately unsuccessful endeavor supporting exploration of the North West Passage. We also know from these writings that the aforementioned spirits permitted Gilbert some familiarity with Dee and his scryer Edward Kelley's angelic sessions, confirming that "He may be made priuie of some things: such as shall be necessarie". ${ }^{16}$ This exchange in March of 1583 indicates that Adrian Gilbert had, at the very least, a glancing familiarity with and interest in esoteric matters in addition to the exploratory venture, which itself reflected metallurgical (and possibly chymical) interests.

Chymistry may have been a family affair for the Gilberts. More than a decade earlier, Adrian's brother Humphrey, a renowned explorer, proposed a royal academy for teaching the queen's wards. Its staff included a natural philosopher and a physician who together would "search and try owt the secreates of nature, as many waies as they possiblie may" by practicing and teaching chymistry. ${ }^{17}$ Gilbert specified that both successes and failures would be recorded in clear, concise language, "without Equivocac[i]ons or Enigmaticall phrases" in the interest of bringing "great thinges to light, yf in Awcomistrie [Alchemy] there be any such thinges hidden". Dee subsequently adopted these methods. Sir Humphrey's proposal indicates a special interest among the Gilberts in uncovering the "secreates of nature" through chymistry as well as testifying to the wider appeal of the subject at Elizabeth's court.

His extensive involvement with an intelligent, ambitious man like Dee renders Adrian Gilbert's reputation all the more confounding. Courtiers apparently held him in low esteem. ${ }^{18}$ Dee's own reluctance to admit Gilbert to the inner sanctum of angelic

\footnotetext{
${ }^{15}$ See John Dee, The Private Diary of Dr. John Dee, ed. James Orchard Halliwell (London: Camden Society, 1842); Sloane MS 3188; Meric Casaubon, ed., A True \& Faithful Relation (London, 1659): 28.

${ }^{16}$ Sloane MS 3188, f. 103r.

${ }^{17}$ Sir Humphrey Gilbert, Queene Elizabethes achademy, F.J. Furnivall, ed., (London, 1869): 6.

${ }^{18}$ Glyn Parry, The Arch-Conjuror of England: John Dee and Magic at the Courts of Renaissance Europe (New Haven: Yale University Press, forthcoming 2010): Ch. 14.
} 
sessions and to rely on his skills as an explorer supports this assessment, as does Aubrey's less-than-flattering portrait. ${ }^{19}$ In contrast to his chymical abilities, Gilbert's personality left much to be desired. Aubrey claimed he was "very Sarcastick, and the greatest Buffoon in the Nation; cared not what he said to man or woman of what quality soever". ${ }^{20}$ It appears that he suffered from a lack of interpersonal skills. Why, though, would Dee continue to associate with a man frequently ridiculed as a fool? If he thought ill of Gilbert, why did he even consider the younger man as a possible confidant and inquire of the spirits to confirm? In light of his reputation as a buffoon, why would Mary Sidney Herbert and her husband employ him? In the latter case, at least, it seems possible that his talents as a chymist outweighed any personality defects. The skills required in Wilton's laboratory differed significantly from those necessary for navigating the niceties of the court.

Lady Mary's connections to Boston, Thomas Moffet and Adrian Gilbert indicate that her chymical practice took many forms. She engaged in iatrochemistry that benefited her household and possibly the surrounding community. Like the queen, it appears that the countess of Pembroke believed in the legendary powers of the philosopher's stone, and would have supported a less avaricious seeker than Boston. Her laboratory also allowed her to delve into Dame Nature's mysteries through experimentation with Adrian Gilbert. Given Dee's longstanding association with both the family into which Mary was born and the one she joined through marriage, it is unsurprising that the countess admitted to her service a chymist trained by the magus. Dee's connections to Lady Mary's immediate family reveal a strong distaff tradition of proto-scientific enthusiasm and chymical patronage among the Dudleys and Sidneys.

\footnotetext{
${ }^{19}$ See BL MS Sloane 3188, fols. 65r, 66v, cp. TNA: SP 15/28 Part I/54.

${ }^{20}$ Aubrey, Brief Lives, 139.
} 
John Dee influenced Lady Mary’s life before she was born. In February of 1552, he entered the service of the Pembrokes following the death of the duke's first wife. He may have tutored young Henry Herbert, who would become Mary's husband, at this time. Dee next joined the Duke of Northumberland's household, educating Robert Dudley, the future earl of Leicester. ${ }^{21}$ There he dedicated to Jane Guildford Dudley, Mary's maternal grandmother, two manuscript treatises on natural philosophy that she had commissioned: "The true cause, and account (not vulgar) of Fluds and Ebbs: written at the request of the right honorable Lady, Lady Jane, Duchesse of Northumberland — anno—-1553" and "The Philosophicall and Poeticall Originall occasions, of the Configurations, and names of the heauenly Asterismes: written at the request of the same Duchesse". ${ }^{22}$ Dee went on to teach mathematics, astronomy and navigation. His students during the next three decades included Adrian and Humphrey Gilbert, their half-brother Walter Raleigh, and Sir Philip Sidney, Lady Mary's eldest brother. While there is no evidence that Mary studied under Dee, she may have joined her brother in chymical training with the magus.

The duchess of Northumberland bequeathed an interest in the natural world to her daughter Mary, Mary Sidney Herbert's mother and namesake, who “surpass[ed] her sex and her generation in excellence of wit and of skills in arts". 23 The daughter of John Dudley, Duke of Northumberland, and Jane Guildford, Mary Dudley counted among her siblings Guildford Dudley, husband of the "nine days queen”, Lady Jane Grey; Robert Dudley, Queen Elizabeth's favorite and earl of Leicester; Ambrose Dudley, earl of Warwick following their father's demise; and Katherine Dudley, wife of Henry Hastings, the earl of Huntingdon. This high-profile Protestant family maintained close connections with the court and other like-minded clans.

\footnotetext{
${ }^{21}$ French, John Dee, 126-7.

${ }^{22}$ John Dee, A letter, containing a most briefe discourse apologeticall (London, 1599), sig. A4r.

${ }^{23}$ Thomas Moffet, Nobilis or A View of the Life and Death of a Sidney and Lessus Lugubris, eds. Virgil B. Heltzel and Hoyt H. Hudson (San Marino: Huntington Library, 1940): 86.
} 
Known for her interest in chymistry, Mary Dudley Sidney patronized John Dee and, like her daughter, experimented with Adrian Gilbert. ${ }^{24}$ Indeed, she acted as conduit between the magus and the royal privy chamber, where in 1562 she had nursed Elizabeth I through smallpox. This event affirms their close relationship and suggests that she may have had a reputation as a healer. Lady Sidney would be the first to embrace the queen's new chymically derived iconography with her 1573 New Year's gift, a jeweled pelican pendant resembling the chymical vessel of the same name. ${ }^{25}$ Until that same year, she and her husband controlled the Sussex ironworks he had inherited from his father, and Henry Sidney, like Pembroke and William Cecil, held shares in the Mines Royal, highlighting the undeniable connection between the raw materials of chymistry and metallurgy. ${ }^{26}$

The Sidneian preoccupation with transmutation can be better understood in light of the family's declining finances, just as the state of the royal treasury contextualized the queen's patronage. In November 1565 Henry corresponded with Cornelius de Lannoy on the subject of chymistry. ${ }^{27}$ Thanks to the support of his brother-in-law, the earl of Leicester, the following year Henry obtained the post of Lord Deputy in Ireland, where he quickly faced opposition, distrust and organized revolts. ${ }^{28}$ He returned in 1571 deeply in debt, the same year that Dee received "Lady Sydneys...most courteous and many letters unto me, and inviting me to court". ${ }^{29}$ She may have hoped to restore the family fortunes with the Great Work. Just weeks after Henry's return, Queen Elizabeth sent Dee to France for a cartful of "purposely made vessels", some intended for the work commissioned by

\footnotetext{
${ }^{24}$ Parry, Arch-Conjuror, Ch. 8.

${ }^{25}$ John Nichols, Progresses, Public Processions, \&c. of Queen Elizabeth, Vol. I (London: Society of Antiquaries, 1823): 324.

${ }^{26}$ D.W. Crossley, "The Management of a Sixteenth-Century Ironworks" in The Economic History Review, Vol. 19, No. 2 (1966): 273-88.

${ }^{27}$ TNA: SP 12/40/49. On de Lannoy, see Chapter 1.

${ }^{28}$ Wallace T. MacCaffrey, "Sir Henry Sidney (1529-1586)," ODNB, online edn. [http://www.oxforddnb.com/view/article/25520, accessed 12 September 2010].

${ }^{29}$ John Dee, Compendious Rehearsal, (London: 1597), Ch. 3.
} 
the Sidneys. ${ }^{30}$ Unfortunately, no evidence that Dee performed transmutations for Sir Henry and Lady Sidney survives.

Another 1571 venture, however, attests to the family's belief in chymical methods. William Medley, a distant relative of William Cecil, attracted numerous noble patrons with his industrial-scale plans to transmute iron into copper using a technique from Agricola's De Re Metallica. ${ }^{31}$ Cecil, the earl of Leicester and his brother Ambrose, earl of Warwick, Sir Thomas Smith, Sir Humphrey Gilbert and Henry and Mary Sidney all backed Medley’s "Society for the New Art", which undertook work in one of Lord and Lady Mountjoy's Poole copperas (ferrous sulphate) houses. ${ }^{32}$ In December 1571 the queen granted the Society a patent not only to "make of iron very true and perfect and good copper", but also to transmute antimony and lead into quicksilver. Medley, who had previously refused to work until he was added to Mountjoy's lease, once again protested upon learning that the monopoly omitted his name. Without royal protection, he feared that Mountjoy would appropriate "knowledge of the secrettes" he had unearthed. ${ }^{33}$ He even suspected his own partners of treachery. ${ }^{34}$ The chymist's paranoia and costly methods survived the disappointing Poole endeavour, but a subsequent project in Anglesey left him imprisoned in the Counter. Medley's failure to produce the promised riches had incurred the wrath of Leicester and Warwick and left him vulnerable to slander from other chymists. ${ }^{35}$ In defiance of her brothers, only Mary Dudley Sidney rose to Medley's defense against the "continewalle mallisius prosecutinge" he suffered. ${ }^{36}$ At the heart of the conflict Lady

\footnotetext{
${ }^{30}$ Julian Roberts and Andrew G. Watson, eds., John Dee's Library Catalogue (London: Bibliographical Society, 1990): 197. Discussed in Parry, Arch-Conjuror, Ch. 8.

${ }^{31}$ Reynold Wolf presented this book to Queen Mary as a New Year's gift during her reign, reinforcing the link between royalty and the royal art. See Nichols, Progresses, xxxiv-xxxv. "Society of the New Art" (Patent Rolls, 14 Eliz., pt. xii) in Sir Cecil Thomas Carr, Select Charters of Trading Companies, A.D. 15301707 (New York: Burt Franklin, 1970): 20-8.

32 TNA: SP 12/188/21, SP 12/86/14.

${ }^{33}$ TNA: SP 12/86/14.

${ }^{34}$ For a more detailed account, see James Campbell, "The Alchemical Patronage of Sir William Cecil, Lord Burghley" (Master's thesis, Victoria University of Wellington, 2009): 128-46.

${ }^{35}$ TNA: Hatfield House, Cecil Papers, M485/42, Edward Osborne and Wolstan Dixie to Cecil, 12 September 1576. For extensive analysis of the Medley case, see James Campbell, "The Alchemical Patronage of Sir William Cecil, Lord Burghley" (Master's thesis, Victoria University of Wellington, 2009): 128-46.

36 TNA: Lansdowne Vol/23 f. 184, Lady Sydney to Lord Burghley, September 1576.
} 
Sidney perceived "some old grudge" between Medley and his enemies, who "shewed no less yll meaninge towardes me and in the open fase of the world, $\mathrm{w}^{\text {th }}$ out all regarde of me, to bringe my name in $\mathrm{w}^{\text {th }}$ his in all theas brables". ${ }^{37}$ Although by protecting the chymist she and her husband had patronized she risked publicly damaging her reputation, she nevertheless stood by her convictions. Lady Sidney — and her family's chymical interests - would recover from this incident. They would also continue to patronize chymists.

The first entry in John Dee's diary documents a visit from young Philip Sidney, his maternal uncle Robert, and friend and fellow courtier Edward Dyer: "1577. Jan. 16th, the Erle of Lecester, Mr. Phillip Sydney, Mr. Dyer, \&c., came to my howse" ${ }^{38}$ They may have sought his astrological services; Philip would head to Europe as Elizabeth's representative twice that year, hoping to resolve Protestant differences over the Eucharist. As former students of the magus, all three men valued his knowledge. Leicester's chymical background led him to back ventures such as Medley's Society, and Dee had known Dyer since 1566. An intimate friend of both Philip and Mary, Dyer supported his former teacher throughout his life and maintained an interest in chymical matters, helping to test a sample of Frobisher's ore in the wake of a 1576 voyage he, Philip and Lady Sidney had patronized. ${ }^{39}$ Later, he would liaise with Dee and Kelley in Bohemia for the queen.

Although Philip mocked the magus's pretensions behind his back, Dee would alter the course of his life. ${ }^{40}$ Lady Mary's physician, Thomas Moffet, posthumously memorialized Philip's fascination with “the inner-most penetralia of causes; and by that token, led by God, with Dee as teacher, and with Dyer as companion, he learned

\footnotetext{
37 Ibid.

${ }^{38}$ Dee, Private Diary, 3.

${ }^{39}$ French, John Dee, 127-9; H.R. Woudhuysen, "Sir Philip Sidney (1554-1586)," ODNB, online edn. [http://www.oxforddnb.com/view/article/25522, accessed 29 March 2010].

${ }^{40}$ Parry, Arch-Conjuror, Ch. 2.
} 
chemistry, that starry science, rival to nature". ${ }^{41}$ Moffet's Sidneian celebration targeted Philip's nephew, Mary's son, and tended toward the hyperbolic. However, as a Paracelsian physician himself, his expertise in this area cannot be denied. "The variety of opinions, the tricks of the teachers, the high costs, the uncertainty of results...have somewhat deterred (as I well know) me, myself”, Moffet wrote, observing that Philip's desire for complete learning triumphed over these obstacles. ${ }^{42}$ It is worth noting that Dee counted Sir Francis Walsingham, Elizabeth's “spymaster", among his friends, and the proximity of their homes permitted regular visits. In 1583 Philip would marry Walsingham's teenage daughter, Frances, who later became godmother to one of Dee's children alongside Margaret Clifford, the countess of Cumberland and a chymist herself. ${ }^{43}$ We find additional connections to Dee's hermetic perspective in Philip's association with the Polish prince Albrecht Laski, who would lead the magus to the Continent, Thomas Allen, Oxford mathematician and occultist under whom he studied, and Giordano Bruno, whose dedication of La cena delle ceneri to Sidney in 1584 indicates that the Dominican philosopher, at least, perceived parallels in their thinking. ${ }^{44}$ Philip's awareness of the principles driving early modern chymistry and hermeticism may suggest that his sister, with whom he saw eye-to-eye on a variety of matters, possessed similar knowledge. At Wilton House, Lady Mary acted as patron and purveyor of such knowledge.

Mary Sidney Herbert provided the Sidney — or Wilton — circle's best-known setting. Aubrey claimed that "Wilton House was like a College, there were so many learned and ingeniose persons. She was the greatest Patronesse of witt and learning of any Lady in her time". ${ }^{45}$ From childhood learning formed an integral part of her life. Born at

\footnotetext{
${ }^{41}$ Moffet, Nobilis, 75.

42 Ibid.

${ }^{43}$ Dee, Private Diary, 53.

${ }^{44}$ A.J. Turner, "Thomas Allen (1540?-1632)," ODNB, online edn. [http://www.oxforddnb.com/view/article/387, accessed 30 September 2010].

${ }^{45}$ Aubrey, Brief Lives, 138.
} 
Tickenhall Palace in Worcestershire on 27 October 1561, Mary was the only Sidney daughter who survived to adulthood, along with her brothers Philip, Robert and Thomas, to whom she remained close throughout her life. The children's formative years found them in Dublin and Ludlow in Shropshire, as well as Penshurst, the family manor in Kent, where they received humanist educations. ${ }^{46}$ As a girl Mary learned Italian and French, and later literary dedications imply her familiarity with both Latin and Greek. She likely knew how to speak Welsh, if not write it. Her knowledge of scripture was matched by familiarity with the classics, and extensive training in rhetoric may have formed the foundation for the lively debate at Wilton House over which she presided later in life. The family account books as interpreted by Margaret P. Hannay indicate musical as well as intellectual skills, and she doubtless augmented these with the medical and culinary knowledge expected of gentlewomen. ${ }^{47}$

At Queen Elizabeth's invitation, thirteen-year-old Mary left home for the court. She would have delighted in the splendid festivities at Kenilworth in the summer of 1575. ${ }^{48}$ Mary’s uncle and Elizabeth's favorite, Robert Dudley, Earl of Leicester, organized nearly three weeks of merrymaking for the queen and her entourage, complete with trumpeted fanfare, a multi-day hunt, music, dancing and unexpected encounters with mythological, literary and allegorical figures - classical Greek deities and the Arthurian Lady of the Lake among them - that the Sidney circle would embrace. ${ }^{49}$ With Leicester's assistance, Mary became the third wife of Henry Herbert, Earl of Pembroke, on 21 April 1577. She received life interest in a number of properties in Dorset, Wiltshire, Devon, Glamorgan, Monmouthshire, Sussex, Kent and Surrey thanks to her uncle's negotiations. ${ }^{50}$ By marrying into the Herbert family, Mary Sidney cemented her place in the history of

\footnotetext{
${ }^{46}$ Margaret Patterson Hannay, "Mary Sidney (1561-1621)," ODNB, online edn. [http://www.oxforddnb.com/view/article/13040, accessed 1 July 2009].

${ }^{47}$ Hannay, Phoenix, 27, 115.

${ }^{48}$ Hannay, "Mary Sidney," ODNB.

${ }^{49}$ Susan Doran, Monarchy and Matrimony: The Courtships of Elizabeth I (London: Routledge, 1996): 67-9.

${ }^{50}$ Hannay, Phoenix, 41.
} 
Protestant gentry in early modern England and augmented her chymical connections.

The Pembrokes spent most of their time at Wilton House, their country estate in Wiltshire, and, to a lesser extent, nearby Ivychurch and Baynards Castle in London. Family and friends frequently visited. For Lady Mary, Wilton was a site of chymistry, creativity and creation. In 1580, with the birth of William, later the third Earl of Pembroke, she bore the heir her husband had so long desired. The Pembrokes took an active interest in their eldest child's future; in 1588 either Mary or her husband commissioned Willam's nativity from the Oxford astrologer Thomas Allen, who had connections to Mary's brother Philip Sidney, her uncle Robert Dudley and John Dee. ${ }^{51}$ This surprisingly accurate scheme would be revised after 1604, suggesting that the new earl himself — or his mother — consulted Allen again for an update. During the next few years Lady Mary gave birth to Katherine, Anne and Philip. Katherine tragically died as a toddler on the day Philip was born, and Anne perished in her early twenties, but Philip would succeed his elder brother as the fourth Earl of Pembroke. ${ }^{52}$ At Wilton, during her children's youth, we find the countess in her prime.

She may not have been permitted a university education, but this did not stop Mary from cultivating Wilton as a school or literary salon akin to those in Europe. Many participated in poetry exchanges, and she meted out assignments to her students with the goal of improving English literature. Sir Philip's dedication of the original Arcadia to his sister, the "Defence of Rhyme" by Samuel Daniel and Thomas Howell's Howell His Devises confirm Mary’s assignation of work. ${ }^{53}$ Furthermore, Daniel in 1607 acknowledged Wilton House as his "best school” and Mary a source of great encouragement. ${ }^{54}$ Thomas Churchyard remarked in his 1593/4 poem "A Pleasant Conceit" to the queen that Mary "sets to school our poets everywhere, / That do presume the laurel

\footnotetext{
${ }^{51}$ See Bodleian Library MS Ashmole 350, pt VI; Turner, "Thomas Allen," $O D N B$.

${ }^{52}$ Hannay, "Mary Sidney," ODNB.

${ }^{53}$ Martin Garrett, Sidney: The Critical Heritage (London: Routledge, 2003): 94-5.

${ }^{54}$ Samuel Daniel, Selected Poetry and A Defense of Rhyme, Geoffrey G. Hiller, ed., (Asheville: Pegasus Press, 1998). Dedicated to Mary's younger son, Philip.
} 
crown to wear". ${ }^{55}$ We can only speculate to what extent the ideas penned were her own, those of her charges or a collaborative effort. By examining the countess's own words we can gain a better understanding of how chymistry informed her life.

In 1586 twenty-four-year-old Mary Sidney Herbert confronted the deaths of her father, mother and brother Philip. These beloved family members left behind a chymical inheritance that enabled the countess to transform her loss into creativity and creation. She withdrew from the public eye, mourning at Wilton House for two years before re-emerging in grand style. This process of sequestration and transmutation rather poetically recalls the early stages of the Great Work, which require the death or dissolution of a base metal into the prima materia, a purified version of itself. The old body putrefies at the base of the vessel, releasing the metal's soul. Its spirit rises in the form of a volatile vapor that subsequently descends as celestial rain or dew, signifying the secret fire that cleanses the corrupt body. ${ }^{56}$ Lady Mary transformed herself with words.

Philip had left his revision of Arcadia incomplete, the euphuistic romance ending mid-sentence. Mary, for whom he had begun the work, with whom he had shared drafts, took it upon herself to fulfill his vision. In her version, the more complex tale he had developed ends with his original conclusion. The countess's editorial decisions have been the subject of extensive debate among scholars, but for our purposes what matters most is the self-identification of brother and sister. ${ }^{57}$ Historians have paid much attention to the writings that the siblings left behind, overlooking how these literary achievements reflect the Sidney family's chymical interests. Mary and Philip's complementary roles in the creation of Arcadia echo the chymical union of opposing forces and their myriad

\footnotetext{
${ }^{55}$ Sasha Roberts, “Women's Literary Capital in Early Modern England: Formal Composition and Rhetorical Display in Manuscript and Print" in Women's Writing, Vol. 14, No. 2 (2007): 262.

${ }^{56}$ Lyndy Abraham, A Dictionary of Alchemical Imagery (Cambridge: Cambridge University Press, 1998): 1 and passim.

${ }^{57}$ Among the literary scholars and historians who have addressed this issue are Albert Feuillerat, Mario Praz, R.W. Zandvoort, A.G.D. Wiles, Jean Robertson, Katharina Wilson, Kenneth Thorpe Rowe, William L. Godshalk, Joan Rees and Richard Lanham.
} 
representations; the coniunctio frequently takes the form of brother and sister who, in dying — symbolically, in Mary's case, through her seclusion — produce a more perfect being. ${ }^{58}$ Their first philosophical child was published in 1593 as The Countess of Pembroke's Arcadia.

Unlike most women who put pen to paper, Mary Sidney’s audience extended beyond herself or members of her immediate family. Extant writings from the estates of Samuel Daniel, Thomas Moffett, Edmund Spenser and Edward Wotton indicate that each of these men were privy to drafts of her works, among them poems written to honor her brother. "The Dolefull Lay of Clorinda" is pastoral in style, while the later pair included in the Sidney Psalter, "Euen now that Care" and "To the Angell Spirit," portray Philip as a Protestant martyr. By addressing the "thrice sacred Queen", the former recalls both the Holy Trinity and chymistry's Hermes Trismegistus, the "thrice great" Mercurius. In the latter, Mary recognizes her brother's dual role in the creation of the psalms, "[f]irst raised by thy blessed hand, and what is mine / Inspired by thee, thy secret power impressed. / So dared my Muse with thine itself combine, / As mortall stuff with that which is divine". ${ }^{60}$ The very creation of the Psalter constitutes a chymical wedding of sorts, the work of mortals inspired by divinity who, together, birth these psalms bridging the terrestrial and heavenly spheres.

"To the Angell Spirit" contains a number of chymically significant phrases. Mary explicitly refers to Philip as a phoenix, acknowledging the death that prompted her efforts and the work through which he is reborn. Associated with the philosopher's stone, Jesus Christ and the queen herself, as we have seen, the phoenix symbolizes renewal and resurrection in the Great Work's final stage, the rubedo. ${ }^{61}$ It is the very product of the

\footnotetext{
${ }^{58}$ Abraham, Dictionary, 106. Stanton J. Linden, Darke Hieroglyphicks: Alchemy in English Literature from Chaucer to the Restoration (Lexington: University Press of Kentucky, 1996): 176.

${ }^{59}$ Hannay, "Mary Sidney," ODNB.

${ }^{60}$ Sir Philip Sidney and Mary Sidney Herbert, The Sidney Psalter: The Psalms of Sir Philip and Mary Sidney (Oxford: Oxford University Press, 2009): 8-9.

${ }^{61}$ Abraham, Dictionary, 152.
} 
coniunctio. The countess perceived in her brother the unearthly perfection of the philosopher's stone that, by “exceeding Nature's store" — as chymists aimed to do granted him everlasting life. ${ }^{62}$ Anyone who reads the works Mary and Philip created together bears witness to this life, produced during the destructive, transcendent unification of the coniunctio. ${ }^{63}$ She goes on to imagine her brother "fixed among thy fellow lights" in the sky, recalling Thomas Moffet's description of chymistry as "that starry science" in his eulogy of Philip. ${ }^{64}$ It is clear that Mary did more than practice iatrochemistry and dabble in chrysopoeia; she also employed the highly symbolic language of chymistry in seemingly unrelated literary compositions.

A dialogue written for the queen provides further evidence of chymically resonant language. In anticipation of a visit from Elizabeth to Wilton in 1599, Mary drafted a pastoral panegyric on Astraea, the "starry maiden" of the constellation Virgo whom writers and artists often identified with Elizabeth. We see her, for instance, in Isaac Oliver's "Rainbow" portrait. As Astraea, the queen has restored the Golden Age characterized by justice and unified imperial religion, associating virtue and royal power. ${ }^{65}$ Astraea had clear ties to the Last World Emperor (or Empress) mythology that chymists had long embraced. Lady Mary's rather oblique dialogue seems to subvert itself by questioning the sincerity and validity of conventional praise; Thenot extols Astraea's virtues only to be interrupted repeatedly by his companion, Piers, who suggests, also in verse, that such extravagant poetry serves only to obfuscate the truth. The countess thus engaged with the queen by means of a common symbol with chymical associations. By reversing the perspective, we can examine how others acknowledged the countess of Pembroke's chymical expertise when writing about her.

\footnotetext{
${ }^{62}$ Sidney and Herbert, Sidney Psalter, 9.

${ }^{63}$ Linden, Darke Hieroglyphicks, 178-9.

${ }^{64}$ Sidney and Herbert, Sidney Psalter, 9; Moffet, Nobilis, 75.

${ }^{65}$ Frances A. Yates, Astraea: The Imperial Theme in the Sixteenth Century (London: Pimlico, 1993): 38-9.
} 
Through the lens of her contemporaries we can obtain a clearer picture of Lady

Mary herself and learn how she was perceived during and shortly after her lifetime. From 1588 until her husband's death in 1601 , the countess was the preeminent female patron of English literature. Members of the Sidney circle repeatedly dedicated works to her, while strangers enthusiastically praised Lady Mary with an eye to receiving funding from the Pembrokes. She encouraged creativity in those around her rather than actively seeking out talented writers to support. ${ }^{66}$ Of those who spent time at Wilton, only Edmund Spenser and Samuel Daniel have left behind a significant literary legacy, although Thomas Moffet's medical and natural philosophical work also had lasting impact. Spenser's dedications typically emphasized his friendship with Philip. He was well established as a writer by the time Lady Pembroke gained renown as a patron. Daniel, by contrast, acknowledged his debt to the countess. He would subsequently receive the patronage of another chymical woman, Margaret Clifford, as we will see in Chapter 5.

Numerous members of the household dedicated works to Mary. ${ }^{67}$ For instance, Moffet, the family physician, recognized the countess's influence in print. He followed an earlier scientific publication on entomology with a parodic work called Silkewormes and their flies in 1599. This he addressed to Mary, "the Most Renowned Patronesse and noble Nurse of Learning". ${ }^{68}$ Moffet's extensive medical training makes his assessment of the countess as more than a mere patron all the more striking. By addressing her as a "Nurse of Learning", he credits her with a role parallel to his own but in a different context. Moffet presents the countess in an appropriately maternal position, as caretaker, but one who nourishes knowledge and, perhaps, creativity. He thus frames her muse-like relation to the Sidney circle in medical — and domestic — terms. His dedication then takes on a

\footnotetext{
${ }^{66}$ Mary Ellen Lamb, “The Countess of Pembroke's Patronage” in English Literary Renaissance, Vol. 12, No. 2 (1982): 163, 178.

${ }^{67}$ These include books by Samuel Daniel; Gervase Babington, the chaplain at Wilton; Sir John Davis, Pembroke's secretary; and Hugh Sanford, the children's teacher.

${ }^{68}$ Thomas Moffet, The silkewormes, and their flies: liuely described in verse, by T.M. a countrie farmar, and an apprentice in physicke (London: Valentine Simmes, 1599), dedication. Moffet later wrote Nobilis for Mary's son William.
} 
cautionary tone, advising the countess to "Vouchsafe a while to lay thy taske aside, / Let Petrarke sleep, giue rest to Sacred Writte, / Or bowe, or string will break, if euer tied, / Some little pawse aideth the quickest witte". ${ }^{99}$ As a physician familiar with Lady Mary, Moffet's assessment reveals that her activities may have possessed a fevered, unearthly quality. She worked hard to cultivate an image of brilliance and possibly overextended herself.

Others who were not so well acquainted with Mary took an active interest in Pembroke's patronage. Abraham Fraunce was prolific in his desire to obtain backing from the Sidney circle after the death of Philip, his former patron; in 1588 alone he dedicated Arcadian Rhetorike to Mary, Lawyers Logike to the earl and Insignium, Armorum, Emblematum, a treatise on the nature of emblems, to her brother Robert. The chymical associations evoked by the last of these suggests that Philip may not have been the only Sidney who studied the subject with Dee. Fraunce addressed subsequent works to Lady Pembroke. The dedication to Thomas Watson's posthumously published Amintae Gaudia highlights Lady Mary's virtue and wisdom. Attributed to Christopher Marlowe, the 1592 Latin verse addresses her variously as "the most illustrious heroine, decked with all gifts of mind and of body", "nourishing parent of literature", "Muse of the poets of our time and of all most happily budding wits" and "Mistress of the Muses". ${ }^{70}$ These words consistently emphasize her role as both a source of inspiration and guidance.

With the exception of the Virgin Queen, writers rarely accorded respect in print for a woman's intelligence. In the 1609 edition of his Civile Wares, Samuel Daniel, her children's tutor, bypassed effusive praise to pay Lady Mary an unexpected, highly unusual compliment: "a carefully reasoned statement of his methodology and purpose". ${ }^{71}$ This is not the only case of the countess being granted such an honor. Indeed, only she and

\footnotetext{
${ }^{69}$ Moffet, The silkewormes, dedication.

${ }^{70}$ Thomas Watson, Amintae gaudia Thoma VVatsono Loninensi, iuris studioso (London: P. Short, 1592), dedication. See Peter Farey's translation [http://www2.prestel.co.uk/rey/pembroke.htm].

${ }^{71}$ Hannay, Phoenix, 119.
} 
Elizabeth I garnered a mention in Francis Meres’s 1598 treasury Palladis Tamia, which discussed the leading contemporary poets, including Shakespeare. He compares Lady Mary to Octavia and asserts that "she is a most delicate Poet, of whom I may say, as Antipater Sidonius writeth of Sappho: Dulcia Mnemosyne demirans carmina Sapphus, Quaesivit decima Pieris unde foret". ${ }^{72}$

Mary Sidney is most frequently remembered through William Browne's print epitaph, which, while noting her wisdom and patronage, praises her in relation to the men in her life: "Vnderneath this sable Herse, / Lyes the subject of all Verse; / Sydney's Sister, Pembroke's Mother: / Death ere thou hast kill'd another, / Learned, fair, and good as she, / Time shall throw a dart at thee". ${ }^{73}$ In contrast, Simon van de Passe's 1618 engraving of the dowager countess gives us an inkling of how she wished to be remembered. ${ }^{74}$ Attired gloriously in pearls and lace, she sits beneath a laurel wreath crowning the Sidney pheon. The self-presentation honors her in Latin and English as "The Right Honorable and most Vertuous Lady". Mary holds in her hands a copy of David's Psalms, a reminder that, like her brother, she endures through the words she imbued with chymical meaning and creativity.

Significant chymical conjunctions marked the trajectory of Mary Sidney Herbert's life. Dedicated from childhood to learning and schooled in the skills that befitted a proper gentlewoman, she possessed natural philosophical, medical and culinary expertise. Chymistry would have taken her from the garden to the still-room or distillery. The dubious, occasionally apocryphal nature of the accounts in Brief Lives, including that of the countess of Pembroke, admittedly contain internal contradictions and factual

\footnotetext{
${ }^{72}$ Francis Meres, Palladis tamia (London, 1598), p. 284v. "Sweet Mnemosyne, amazed at the poems of Sappho, asked from whence she became the tenth muse".

${ }^{73}$ William Herbert, Poems written by the Right Honorable William earl of Pembroke, lord steward of his Majesties houshold (London: Matthew Inman, 1660): 66.

${ }^{74}$ Engraving held by the National Portrait Gallery, London

[http://www.npg.org.uk/collections/search/portrait/mw77746/Mary-Herbert-Countess-of-Pembroke].
} 
inaccuracies. However, Aubrey's assertion that she annually devoted much time or money (presumably both) to the study of chymistry coheres with her interests and associations. For a woman to whom family was of the utmost importance, she counted a number of male and female practitioners among her relatives. Furthermore, we find at least one practicing chymist among her acquaintances, and another in her employ. Contemporary manuscript evidence supports the possibility that Mary Sidney Herbert and Adrian Gilbert worked together in a chymical context. It also indicates that she employed chymistry for medical purposes and developed a reputation as a healer whose cures, like her literary contributions, circulated long after her death. 


\section{Chapter 4}

\section{Margaret Hoby}

Whereas historians must piece together evidence of Mary Sidney Herbert's chymical engagement, Margaret Hoby (1571-1633) left clues in the spiritual journal she kept between 1599 and 1605. This earliest known diary by an Englishwoman serves as a considerable, tangible legacy for a woman who bore no children, providing a vivid impression of daily life in turn-of-the-seventeenth-century Hackness, Yorkshire. Mistress to a large country household, Lady Margaret presided over considerable agricultural and horticultural resources that supplied food and medicines not only to those living under the Hoby roof, but also as an expression of Christian beneficence to the poor and needy in the area. ${ }^{1}$ The Puritan convictions she shared with her ambitious husband to some extent isolated them from their predominantly Catholic neighbors. However, these same beliefs enabled Margaret to connect with her community in significant ways. Following a brief biographical sketch, this chapter explores the relationship between iatrochemistry, medicine and religion in her life by examining, in turn, Lady Hoby's healing skills, direct evidence of chymical activities and her association with other chymists.

Margaret Dakins was the only child of a Yorkshire gentleman, Arthur Dakins, and his wife Thomasine. Baptized on 10 February 1571, much of her childhood education took place at the home of Henry Hastings, the earl of Huntingdon, in Ashby-de-la-Zouch. ${ }^{2}$ Hastings's wife Katherine (née Dudley) was Mary Sidney Herbert's aunt, younger sister to her mother. She shared her family's staunch Protestant beliefs. While Henry aligned

\footnotetext{
${ }^{1}$ On the lives of the gentry, see Felicity Heal and Clive Holmes, The Gentry in England and Wales, 15001700 (Stanford: Stanford University Press, 1994): 3-19, 51, 286 and passim.

${ }^{2}$ Paul Slack, "Margaret Hoby (bap. 1571, d. 1633)," ODNB, online edn. [http://www.oxforddnb.com/view/article/37555, accessed 11 November, 2009]. See also Joanna Moody, ed., The Private Life of an Elizabethan Lady: The Diary of Lady Margaret Hoby, 1599-1605 (Thrupp: Sutton, 1998): xvi-xvii.
} 
firmly with the Protestant camp, his mother's cousin was Cardinal Pole, who had reconciled England to Rome during Mary's reign. His younger brothers were discreet Catholics, and two of their cousins had plotted a religiously motivated overthrow of Elizabeth in $1561 .^{3}$ The earl and countess of Huntingdon emphasized the Puritan virtue of self-examination in the upbringing of all of their charges, and their guidance was to have enormous impact on Margaret's future. She could draw upon her youthful experiences in the Huntingdon household as the model for her own estate. Like Margaret, Katherine was childless; she alleviated the pain this may have caused her by training young people. In 1618 she assured Sir Julius Caesar that, "though my self doe say it, I think ther will none make questen, but $\mathrm{j}$ know how to breed and gouern yong gentlewomen". 4 She also opened her home to the three younger children of the first earl of Essex, as well as the countess's favorite nephew, Thomas Sidney, upon the death of his father Sir Henry in $1586 .^{5}$

The Huntingdons obviously influenced Margaret's marital history. As sole heiress to the Dakins fortune, she attracted several suitors, and in 1589 she married Walter Devereux, the younger son of the aforementioned earl of Essex and ward of Henry Hastings. The match gave her powerful political connections. Walter's brother Robert, second earl of Essex, was a favorite of the queen, and their sister Penelope had married Robert, third Baron Rich, despite their father's dying wish that Philip Sidney be his son-inlaw. Margaret in turn offered a substantial fortune. Their families jointly purchased Hackness estate in the North Riding of Yorkshire for the young couple. Unfortunately, Walter was killed during the siege of Rouen in 1591 . The Huntingdons swiftly suggested as his replacement another childhood friend of Margaret's: Thomas Sidney. They spirited her off to London, thwarting the efforts of another suitor, Thomas Posthumous Hoby.

\footnotetext{
${ }^{3}$ See Claire Cross, The Puritan Earl: The Life of Henry Hastings, 3rd Earl of Huntingdon, 1556-1596 (London: Macmillan, 1966); Norman Leslie Jones, The English Reformation: Religion and Cultural Adaptation (Oxford: Blackwell, 2002): 45.

${ }^{4}$ British Museum Lansdowne MS, clxii, f. 124, referenced in Dorothy M. Meads, ed., Diary of Lady Margaret Hoby (London: Routledge, 1930): 7.

${ }^{5}$ Claire Cross, "Katherine Hastings (c. 1538-1620)," Oxford Dictionary of National Biography, online edn. [http://www.oxforddnb.com/view/article/69739, accessed 3 May 2010].
} 
However, it seems that this marriage was not merely prudent, but also genuinely affectionate. ${ }^{6}$ Margaret's second husband tragically died in 1595 . Hoby, though not renowned for either good looks or congeniality, did everything within his power to avoid being rebuffed again. He benefited from the support of his mother, Elizabeth Russell, one of Sir Anthony Cooke's five exceptionally learned daughters, and his cousin, William Cecil, Lord Burghley, who wrote letters on his behalf. ${ }^{7}$ Despite Margaret's initial reluctance, doubts about her ability to defend her ownership of Hackness — and a letter from her dying former guardian — convinced her to give the persistent, if not particularly personable, man a chance. ${ }^{8}$ They were married at his mother's home on 9 August $1596 .{ }^{9}$ Approximately three years later, Margaret began writing her diary, which documented five years of her life to varying degrees. From the start it focused on spiritual matters, recording private and public prayers throughout the day and reflections upon her thoughts and beliefs, especially her shortcomings. As her recent editor, Joanna Moody, has observed, the more mundane aspects of existence increasingly claimed her attention. ${ }^{10}$ Household matters made regular appearances and the entries themselves grew shorter, the gaps between them longer and more frequent. Nevertheless, it provides us with a vivid account of an early modern English gentlewoman's thoughts and activities.

Although the diary gives the impression that most of her days were spent in devotion and reflection, Margaret exercised many responsibilities in presiding over a large estate. She often engaged in needlework and kept track of household accounts. Her leisure time was active, spent playing a stringed instrument called an alpharion, lawn bowling and fishing. Numerous entries relate, directly or tangentially, to chymical study and practice. The estate at Hackness typified the relative self-sufficiency of its kind, encompassing arable and grazing fields, various gardens, orchards, livestock and bees, and

\footnotetext{
${ }^{6}$ See Sir Edward Stanhope's letter of 27 September 1595 in Moody, Private Life, Appendix 1, 233.

${ }^{7}$ See Meads, Diary, 24; Moody, Private Life, xxiv and Appendix 1, 229-30.

${ }^{8}$ See Moody, Private Life, Appendix 1, 235-7.

${ }^{9}$ Ibid., xxviii.

${ }^{10}$ Ibid., 221.
} 
specialized buildings and service rooms dedicated to particular tasks, including a granary, preserving room, pantry and stillroom. ${ }^{11}$ To varying degrees, and depending on her husband's presence or absence, Margaret managed each of these aspects of her household.

Despite its spiritual basis, Margaret's diary contains frequent references to the terrestrial matters of sickness and health care. Early modern medical recipes could be as hazardous as the conditions they treated. On 31 August 1599, she learned that her physician, Doctor Brewer, had suddenly passed away, his death "[p]rocured by a medeson he minestred to him selfe to Cause him to sleep". ${ }^{12}$ Like other charitable gentlewomen, Margaret's relationship with her doctor — and, indeed, the medical profession — was a positive one. She felt genuinely grieved by his passing "because of the familiaritie I had with him, and good I had receiued". Plagued by sickness throughout the period covered by the diary, Margaret would have been in regular contact with her physician. Less than a week earlier she had written him a letter. ${ }^{13}$

Margaret recognized the hand of God in all events, her Protestant perspective informing every aspect of life; as a Puritan, this included viewing the divine as the great physician. ${ }^{14}$ Brewer's skills had eased her own illnesses in the past. Reflecting on the place of medicine and chymistry in God's providence, she wondered whether by focusing on patients like herself Brewer may have neglected his own health: "I found the mercie and power of god shewed in openinge his eies touchinge me, and shuttinge them against him selfe, by Causing him to haue great Care of ministering vnto me, and so little for his

\footnotetext{
${ }^{11}$ Ibid., 10, 154 n. 266.

${ }^{12}$ Ibid., 13. This and subsequent quotes from Margaret's diary are taken from Moody, Private Life; each has been compared with the 1930 edition by Dorothy M. Meads and the manuscript, BL MS. Egerton 2614.

Dates not listed in the text will be included in footnotes.

${ }^{13}$ Ibid., 9 (25 August 1599).

${ }^{14}$ Ibid., 13, n. 35.
} 
own saftie". ${ }^{15}$ Humbled and thankful, she concluded that "it is the Lord, and not the phisision, who both ordaines the medesine for our health and orderethe the ministering of it for the good of his children" ${ }^{16}$ God, of course, presided over any practitioner's medical care as well as the health of his patients, and ultimately decided each person's fate.

Margaret furthermore observed a causal relationship between sin and sickness, experiencing early on as a "[i] ust punishment to correcte my sinnes...febelnis of stomak and paine of my head that kept me vpon my bed tell 5: a clock". ${ }^{17}$ Despite perceiving the divine in disease, she believed that human reason and the bounty in God's creation could be harnessed to find cures, as her iatrochemistry indicates.

Less than a month elapsed before providence sent a replacement for her late doctor, a chymical practitioner who links Margaret to her former sister-in-law, the countess of Pembroke. On 21 September, she wrote, "I talked with a phesition, which, I hope, the Lord hath prouided for me in steed of Doctor Brewer". ${ }^{18}$ We learn from the subsequent entry, dated the following day, that the physician in question was Master Lister — the same man whom Mary Sidney Herbert would employ in subsequent years. ${ }^{19}$ This connection between the two women deserves greater attention, indicating that they influenced one another after Thomas Sidney's death. Margaret's positive experience with Lister likely prompted her former sister-in-law's decision to engage him. Thomas Moffet held the position of family physician to the countess of Pembroke until his death in 1604, at which time Matthew Lister, recent recipient of a Basel medical degree and not yet a knight, replaced him at Wilton House. ${ }^{20}$ The faculty at Basel was supportive of Paracelsian chymical remedies, linking Lister to Theodore Turquet de Mayerne, "whose

\footnotetext{
${ }^{15}$ Ibid., 13 (31 August 1599).

16 Ibid.

${ }^{17}$ Ibid., 6 (15 August 1599).

${ }^{18}$ Ibid., 20.

${ }^{19}$ Margaret P. Hannay, Philip's Phoenix: Mary Sidney, Countess of Pembroke (Oxford: Oxford University Press, 1990), 201.

${ }^{20}$ Brian Nance, "Sir Matthew Lister (bap. 1571, d. 1656)," ODNB, online edn. [http://www.oxforddnb.com/view/article/16764, accessed 6 May 2010].
} 
manuscripts contain a number of Lister's remedies". ${ }^{21}$ Coincidentally, Mayerne acquired Thomas Moffet's medical papers and in 1618 brought to fruition the London pharmacopoeia project Moffet, also a Basel medical school graduate, had championed years earlier.

Although Matthew Lister served Margaret prior to gaining his degree and recognition from the Royal College of Physicians, he nevertheless connected her to the wider medical — and specifically chymical — world. They maintained regular contact through correspondence and visits, and he offered the Hobys a range of treatments. ${ }^{22}$ Face-to-face meetings took place in either Hackness or York, indicating that he practiced not far from his family's hometown of Thornton. The two met socially as well. On 17 April 1600, Margaret "talked with Mr. Lister touchinge sundrie thinges that Concerned more others then my selfe". ${ }^{23}$ In other words, she told him about her own burgeoning medical practice. Their conversation points to Lister's implicit approval of her activities and hints at a discussion of their patients by equals. Mentions of Lister disappear after the summer of 1601, when he may have headed to Basel. We know from the writings of Thomas Moffet and Felix Platter, under whom he studied, that qualified applicants received their medical degrees from Basel in under a year. ${ }^{24}$

The Hobys later became acquainted with Lister's brother, also a doctor, whom they consulted during their extended stay in London. ${ }^{25}$ Sir Matthew was not the only medical practitioner in the Lister family. ${ }^{26}$ His elder brother Edward (1557-1620) was a fellow of the College of Physicians from 1594, firmly situating his practice in London. I propose

\footnotetext{
${ }^{21}$ Ibid.

${ }^{22}$ Moody, Private Life. These include: “a litle phesick", 75 (14 April 1600), "lett blodd”, 76 (18 April 1600) and "glister", 76 (19 April 1600). Margaret mostly noted her own health, but Mr. Lister also treated Thomas when he was ill, 114 (29 September 1600).

${ }^{23}$ Ibid., 76.

${ }^{24}$ See Victor Houliston, “Thomas Moffet (1553-1604)," ODNB, online edn. [http://www.oxforddnb.com/view/article/18877, accessed 8 August 2010]; Emmanuel le Roy Ladurie, The Beggar and the Professor: A Sixteenth-Century Family Saga, trans. Arthur Goldhammer (Chicago: University of Chicago Press, 1997): esp. 316-325.

${ }^{25}$ Moody, Private Life, 135-6 (8 January 1601 and 19 January 1601).

${ }^{26}$ His nephew Martin would also gain renown as a doctor. See the Munk's Roll of the Royal College of Physicians of London [http://munksroll.rcplondon.ac.uk/Biography/Details/2762].
} 
that Edward was the "Dr. Lister" of Margaret's diary based on the time frame and location of this doctor's appearances. Significantly, he served as physician-in-ordinary to both Queen Elizabeth and her successor, thus linking Margaret to the court as well as medical culture in London. ${ }^{27}$

Margaret's medical knowledge first appears in the form of self-administration. Throughout, the diary records preparation and application of various medicaments. On both 7 and 8 December 1599, she took a "glester" (clyster, a suppository or enema); she had not recorded a communication with a physician for more than two months, suggesting that she developed and administered the cure by herself. ${ }^{28}$ These efforts did not always prove successful. On 29 February 1600 she "was forced to vse diuerse medesons that did litle profett", so little, in fact, that she spent more than a week confined to her chamber. ${ }^{29}$ In May and June of that year, she took medicine for an unspecified condition, careful to exercise afterward. ${ }^{30}$ Such behavior was consistent with the approach of Galenic medicine, the holistic nature of which took diet and physical activity into account. Margaret did not assess the effectiveness of this treatment. However, after the second course she did not mention feeling unwell for three weeks. ${ }^{31}$ She suffered a minor injury over the summer; on 5 August 1600 she "was busie about a dressinge for my selfe" that must have done some good, for the next day found her walking with Thomas Posthumous and preserving sweetmeats, as well as her usual devotional exercises. ${ }^{32}$ The next clear instance of self-administration took place on 9 May 1601. Once again Margaret fell victim

\footnotetext{
${ }^{27}$ Norman Moore, rev. Rachel E. Davis, "Edward Lister (1557-1620)," ODNB, online edn. [http://www.oxforddnb.com/view/article/16760, accessed 6 May 2010]. See also "LISTER, Edward" in Margaret Pelling and Frances White, eds., Physicians and Irregular Medical Practitioners in London 15501640: Database (2004), online edn. [http://www.british-history.ac.uk/report.aspx?compid=17625]; and the RCPL Munk's Roll [http://munksroll.rcplondon.ac.uk/Biography/Details/2761].

${ }^{28}$ Moody, Private Life, 42. Aside from the previously discussed entries on 21 and 22 September 1599 (p. 20-1), Margaret did not mention Mr. Lister again until the following April.

${ }^{29}$ Ibid., 65. Margaret mis-dated this entry as 28 February.

${ }^{30}$ Ibid.,. as follows: 16 May 1600 (83), 17 May 1600 (83), 23 May 1600 (84), 3 June 1600 (87), 4 June 1600 (88). Nearly a month had passed since she had been treated by Mr. Lister in York (12 and 14-19 April 1600); she wrote him letters on 28 April (mis-dated 27) and 3 May. I suspect Margaret discussed her symptoms with him and they agreed upon a plan of treatment, which she formulated and administered. ${ }^{31}$ Ibid., 94 (25 June 1600: "I went to supper and then, being not well, I went to bed").

32 Ibid., 103.
} 
to a debilitating toothache for which she "tooke phisicke". 33 The next day she "was for paine Eased," but her face had swollen to the extent that she felt uncomfortable leaving her chamber. ${ }^{34}$ There was a gap of four years before she again noted treating herself. This coincided with a significant decrease in both the frequency and detail of her entries. On 13 May 1605, she wrote, "This day I tooke somthine for my Shoulder, which had a paine in it by reason of Could, $w^{\text {ch }}$, I praise god, did me good : afflictions drawe one nerer to god" ${ }^{35}$ This successful Galenic treatment had been sanctioned by God. Thus she experienced both suffering and healing in the context of her relationship with the divine.

Like many gentlewomen, Margaret regarded healing others as a charitable work. Her diary documents her growing interest in medicine as she gained experience by treating minor ailments, wounds and occasionally more serious complaints. On 16 September 1599, a Sunday, she "looked vpon a poore mans Legg" after the sermon. ${ }^{36}$ The next day she "saw a mans Legg dressed". ${ }^{37}$ Margaret's significantly passive phrasing in this entry suggests that she did not begin practicing charitable medicine herself until early the following year. ${ }^{38}$ Her practice, which catered to both members of her household and the wider community, enjoyed popularity from its inception; on 30 January 1600, she "dressed apoore boies legge that Came to me... after, I dressed the hand of one of our seruants that was verie sore Cutt...after that I dressed one of the mens handes that was hurt". ${ }^{39}$ The nature and level of this activity were unprecedented. They also remind readers of the diary that the events she recounted did not represent the totality of her experience. Margaret's entries surely omit interim steps between seeing a man's leg dressed and dressing multiple wounds in a single day. The diary's diminishing focus on spiritual matters that she would not have neglected strongly suggests that it was a highly selective record. We therefore

\footnotetext{
${ }^{33}$ Ibid., 147.

${ }^{34}$ Ibid.

${ }^{35}$ Ibid., 214.

${ }^{36}$ Ibid., 18.

${ }^{37}$ Ibid. Presumably the same man.

${ }^{38}$ See also ibid., 40 (27 November 1599: "then I walked and did se a sicke man").

${ }^{39}$ Ibid., 58.
} 
must acknowledge the possibility that her medical activities began prior to January 1600 , and that this practice continued even when she grew weary of documenting it. Within a week of that hectic first day she began referring to the people who came to her as patients. ${ }^{40}$ These included the poor, household servants and occasionally relatives. Over the next few months she repeatedly recorded dressing her patients, and reiterated this the following spring. ${ }^{41}$ It is telling that the start of her medical practice follows and coincides with the only three references in the diary to reading an herbal, indicating a connection between these two activities.

Margaret's medical skills extended beyond the simple dressing of wounds. On 12 July 1600, she "made readie a purgatione for my Cosine Isons woman". ${ }^{2}$ This purgative cure was designed to purify the body through evacuation, and may have included culinary, herbal and possibly even mineral ingredients. In his 1597 Herball, with which Lady Margaret was likely familiar, John Gerard named a variety of plants with purgative properties, among them tobacco, rhubarb, mandrake, mustard seeds, the curiously chymical-sounding French mercury, and common flowers such as the iris and daffodil. ${ }^{43}$ She also concocted ointments to alleviate pain and infection. On 18 September 1600 , Margaret "gaue a poore woman of Caton saulue [salve] for her arm". ${ }^{44}$ Similarly, she "made a saule [salve] for a sore breast", though it is not clear whose, on 14 April $1601{ }^{45}$

Her patients seem to have thought highly of her healing skills and certainly viewed her as a resource. The entry for 26 August 1601 illustrates this most clearly and tragically: this day, in the afternone, I had had [sic] a child brought to se that was borne at Solpho, one Talliour sonne, who had no fundement, and had no passage for excrementes but att the Mouth : I was earnestly intreated to

\footnotetext{
${ }^{40}$ Ibid., 59 (4 February 1600: “at 5 a cloke I dressed my patientes").

${ }^{41}$ Margaret dressed her patients as follows in 1600: 31 January; 1-3, 5-19, 21-22, 25-28 February; 11, 16-17, 19, 22-23, 29 March; 2, 4, 28 (mis-dated 27), 30 (misdated 29); and 17 June. See also 17, 18, 23, 25-8 April and 3, 5 May 1601.

${ }_{42}$ Moody, Private Life, 98.

${ }^{43}$ John Gerard, The Herball or Generall Historie of Plantes (London, 1597): 47, 116, 207, 282, 287, 318 and passim.

${ }_{44}^{44}$ Moody, Private Life, 112.

${ }^{45}$ Ibid., 143.
} 
Cutt the place to see if any passhage Could be made, but, althought I Cutt deepe and seearched, there was none to be found. ${ }^{46}$

Two important conclusions may be drawn from this entry: first, that she possessed basic surgical knowledge, and second, that the community she served knew of her skills in this field. Though her efforts were in vain, it must have been heartening to know that when confronted with such a dreadful discovery the desperate parents felt that she represented their child's best hope of survival. Margaret's attempts to provide charitable medical services to the area surrounding Hackness evidently filled a real need.

As was typical of gentlewomen of her time, Lady Hoby also found herself called on by women in childbirth. We cannot be certain she acted as midwife at these times, but she undoubtedly offered support and assistance to the mother and the other women present during delivery, in addition to acting as witness. ${ }^{47}$ Without a child of her own, such events may have been the source of some pain; if so, the diary offers few clues. Moody suggests that we can "make assumptions about a sadness relating to her inability to have children", citing two particular entries. ${ }^{48}$ In the first, dated 30 September 1600, Margaret "talked a whill with Mr Lister of some of my greues". ${ }^{49}$ Three years later, on 7 October 1603, she wrote more explicitly of her pain: "I fasted untill Eueninge, eatinge nor drinkinge any thinge, begging of the Lord that blissne $\mathrm{w}^{\text {ch }}$ yet I want: the Lord Heare me for his Christs sack, amen". ${ }^{50}$ Margaret would certainly have viewed her failure to conceive as a sign from God of another failing on her part. She naturally hoped to redeem herself and regain favor through fasting and prayer. While these entries could express the heartfelt pleas of a barren woman, the absence of further details renders the theory little more than speculation. However, Margaret's barrenness may have played a role in her decision to

\footnotetext{
${ }^{46}$ Ibid., 161.

${ }^{47}$ On the ritual of childbirth, see, for instance, David Cressy, Birth, Marriage, and Death: Ritual, Religion, and the Life-Cycle in Tudor and Stuart England (Oxford: Oxford University Press, 1999); Sara Heller Mendelson, "Stuart Women's Diaries and Occasional Memoirs" in Women in English Society, 1500-1800, Mary Prior, ed. (London: Methuen, 1985): 181-211, esp. 196.

${ }^{48}$ See Moody, Private Life., xliv-xlv.

${ }^{49}$ Ibid., 114.

${ }^{50}$ Ibid., 194.
} 
practice charitable medicine. Fertility treatments fell within the scope of a physician's attention and even that of an ordinary gentlewoman. The Queens Closet Opened, which cites Margaret as a source, also includes a "special remedy for the stone, back, and to make a woman conceive" from "the Countesse of Arundel". ${ }^{51}$ This attribution refers either to Margaret's contemporary, Anne Howard, or Howard's daughter-in-law, Alathea Talbot, who was credited in 1655 with another receipt compendium, Natura Exenterata. Like her mentor Katherine Hastings, it seems that Margaret also compensated for her childless state by schooling the children of others. ${ }^{52}$

We know that she was present at six births. On 15 August 1599, she "went to a wiffe in trauill of child"; this woman remained anonymous, but she named others. ${ }^{53}$ The following year Margaret “went to Eaton, to Mistress DauNies Labour". ${ }^{4}$ Mrs. Dawnay was related to Lady Eure, another neighbor and friend, though the two families quarreled during the period covered by the diary. Three of the remaining instances feature Margaret's own relatives. Her cousin Bouchier requested her presence at the birth of his son on 13 November 1601, and she bore witness to two of her cousin Ison's children, on 4 February 1602 and 19 April $1605 .^{55}$ The latter date was a busy one as Margaret went, "[1]ikewise, to Iosuas wiffe who was brought to bed". Her participation in these communal female activities highlights women's prominent place in the domestic sphere. The same was true of the natural world.

Margaret often spent time in her garden, closet and kitchen, where the lines between culinary and chymical pursuits blurred. Despite its emphasis on faith and God's goodness, the diary frequently lets slip vivid images of her daily life. When not engaged in contemplation, Lady Hoby devoted hours to the preservation of sweetmeats, candle-

\footnotetext{
${ }^{51}$ W.M., The Queens closet opened (London: 1655): 11, 168.

${ }^{52}$ See, for instance, Everill Aske and Elzabeth Darfeld. Moody, Private Life, 31, 40, 182, 211.

${ }^{53}$ Ibid., 6.

${ }^{54}$ Ibid., 79 (1 May 1600).

${ }^{55}$ Ibid., 169, 171, 177 and 212.
} 
making and, in early autumn, harvest-related tasks. She enjoyed walking in her fields, alone or accompanied by "my maides", and usually took her coach to more far-flung destinations. ${ }^{56}$ This kinship with nature reminds us that the labor mulierum extended outside of the house, incorporating, in Margaret's case, the entire estate. Domestic activities that integrated and complemented chymistry play a prominent role in her diary.

More than merely ornamental, the gardens at Hackness offered sustenance. The grounds would have included a flower garden, a plot for herbs and kitchen requirements and an orchard. ${ }^{57}$ Margaret and her maids likely planted carrots, cucumbers, parsnips and leeks in the vegetable garden. ${ }^{58}$ Many estates featured a geometrical arrangement of box hedging called a knot garden. Eighteen diary entries referring to the garden span the years, with the final references in April 1605. ${ }^{59}$ Only occasionally did Margaret elaborate on her time spent there. For instance, on 28 August 1599 she gathered apples, and the following July she found herself "busie with Roses". ${ }^{60}$ On 4 April 1601 she "was almost all the after none in the Garden Sowinge seed". 61 Later that month Margaret exhibited characteristic generosity when she "gaue some hearbes vnto a good wife of Erley for his [sic] garden". 62 The preponderance of springtime entries shows that she devoted a great deal of time to planting each year. Her active interest in what was planted, and when, reflects the fact that, in addition to producing essential ingredients for cooking and dyeing wool, the gardens provided raw materials for Lady Hoby's medical practice.

The diary confirms that she recognized the usefulness of herbs outside of a culinary context. On three separate occasions, she mentioned reading an herbal. After dinner on 17

\footnotetext{
${ }^{56}$ Ibid., 82 (15 May 1600).

${ }^{57}$ Ibid., 10, n. 24.

${ }^{58}$ Ibid., xxxvi. Hoby herself also mentioned artichokes, though these were largely ornamental in early modern times.

${ }^{59}$ I have not included discussions of the fields, harvest or granary in this number. Dates are as follows: 28 August 1599, 14 January 1600, 2 May 1600, 26 May 1600, 22 July 1600, 12 August 1600, 4 April 1601, 8 April 1601, 11 April 1601, 27 April 1601, 29 July 1601, 5 October 1603, 1 November 1603, 5 April 1605, 6 April 1605, 8 April 1605, 9 April 1605 and 13 April 1605.

${ }^{60}$ Moody, Private Life, 11, 100 (22 July 1600).

${ }^{61}$ Ibid., 142.

${ }^{62}$ Ibid., 145 (27 April 1601).
} 
September 1599, Margaret "went about the house, and read of the arball", while the following month she "hard Mrs. Brutnell Read of the Herball tell supper time". ${ }^{63}$ On 2 February 1600, she recorded that "I rede of the arball". ${ }^{64}$ These comprehensive tomes discussed the medicinal virtues of plants. Woodcuts and other illustrations were included to assist laypeople in identifying uncommon plants. Margaret possibly consulted William Turner's A New Herball or, more likely, the Herball or Generall Historie of Plantes that John Gerard had recently published in $1597 .{ }^{65}$ Queen Elizabeth appeared in the guise of Flora on the book's frontispiece, and his regal treatment of Natura, or Mother Earth, confirmed associations with traditionally feminine skills like cooking and healing. ${ }^{66}$ In spite of its inaccuracies and derivative content, Gerard's large-scale work offered those without a medical degree or convenient access to a physician an affordable means of selftreatment. ${ }^{67}$ It required only literacy. For a gentlewoman trying to provide basic medical care to the local poor, such a book would have been a tremendous resource. Gerard followed pictorial representations of each species with structural descriptions, their locations and times of year when they flourished, etymologies and, most importantly, accounts of their usefulness, particularly with respect to physic. The three entries in which the herbal appears coincide with the first references to dressing wounds, a clear indication that she used the text for specifically medical purposes.

Margaret's diary regularly mentions the kitchen and closet, especially during the first two years when she recorded her activities in greater detail. Most interesting is the frequency with which she noted working in her closet. It appears in fourteen different entries between January 1600 and June 1602. While Moody has interpreted the closet as an office, I follow the example of Jayne Archer in associating this versatile space with the

\footnotetext{
${ }^{63}$ Ibid., 18, 29 (15 October 1599).

${ }^{64}$ Ibid., 58.

${ }^{65}$ Turner's work was published in three parts in 1551,1562 and 1568.

${ }^{66}$ Rebecca Laroche, Medical Authority and Englishwomen's Herbal Texts, 1550-1650 (Aldershot: Ashgate, 2009): 56-60.

${ }^{67}$ For the issues with Gerard's herbal, see Deborah E. Harkness, The Jewel House: Elizabethan London and the Scientific Revolution (New Haven: Yale University Press, 2007), Ch. 1.
} 
stillroom. ${ }^{68}$ Based on the diary entries themselves, the function of the room is not immediately apparent. Margaret "dresed vp my Clositte" on at least two occasions, "went to priuat exercises" there, and once spent an entire morning "ordringe thinges in my Clositt and sorting of papers". 99 On 19 July 1600, she "returned vnto my Clossitt and altered that a litle which before I had written". ${ }^{70}$ Several months later, she "took a note of such thinges as are in my Clositte". ${ }^{71}$ From these entries we can develop a clearer picture of this room where she wrote and conducted private exercises. It evidently contained papers and other "thinges" that sometimes needed to be "dresed vp" — that is, straightened or tidied. These things were sufficiently numerous to require listing. Finally, she also deemed the room appropriate for spiritual activities. Her closet was thus a composite space and the likely setting for Margaret's herbal and iatrochemical preparations. Here she may have composed or reviewed the recipes for her salves and ointments, compiling them in a stillroom book, as well as distilled these medicaments and penned letters to Mr. Lister. We need look no further than Gervase Markham's The English House-vvife, first published in 1615, which includes among its directives to his countrywomen the following advice: "I would haue her furnish her selfe of very good Stills, for the distillation of all kinds of Waters". ${ }^{72}$ He intended that distillation be used not only for culinary purposes, but also in the practice of physic. Margaret's medical notes and receipts would certainly have required sorting in order to facilitate regular use. Most interesting is the juxtaposition of these chymical activities with prayer, an intensely private exercise. That she deemed it appropriate to practice both in the same space suggests a significant link between the two. Grace Mildmay's papers, as we have seen, likewise indicate close ties between iatrochemistry and faith.

\footnotetext{
${ }^{68}$ See Moody, Private Life, xl; and Archer, "The Queens' Arcanum: Authority and Authorship in The Queens Closet Opened (1655)" in The Renaissance Journal, Vol. 1, No. 6 (2002), 6

[http://www2.warwick.ac.uk/fac/arts/ren/projects/publications/journal/six/archer.doc].

${ }^{69}$ See Moody, Private Life, 56 (26 January 1600), 64 (27 February 1600, mis-dated 26), 95 (28 June 1600), 144 (22 April 1601).

${ }^{70}$ Ibid., 100.

${ }^{71}$ Ibid., 115 (4 October 1600).

${ }^{72}$ Gervase Markham, The English House-vvife (London: Nicholas Okes, 1631): 141.
} 
Three related entries draw attention to the significance of the stillroom. In the first, on 26 July 1600, she "did musie [busy] my selfe a bout makinge of oile and in my Clositt tell towards diner time". ${ }^{73}$ Two weeks later, early on 9 August 1600, Margaret "went about my stilling" before returning to prayers. ${ }^{74}$ The following year, on 20 July 1601, she "stilld Aqua : Vita". 75 Translated as "water of life," this concentrated aqueous ethanol was used by chymists as a base alcohol to which herbs and other ingredients could be added and further distilled to make essential oils, healing tinctures and more esoteric substances, among them the fabled philosopher's stone. Moody downplays the possibility of chymical involvement, suggesting that Margaret was making "a kind of whisky based on fermented grain". ${ }^{76}$ The Hobys were not enthusiastic drinkers, and neither the wheat, nor the rye, nor the corn, had yet been gathered during the hectic height of summer. ${ }^{77}$ Given Lady Margaret's skill in making her own medicaments and the utility of ethanol in creating them, I propose that she was, in fact, familiar with some chymical concepts and activities, and she cultivated this knowledge in conjunction with her religious beliefs and charitable medical practice. There would have been nothing dishonorable about distilling in order to perform good works in God's name, especially given her connections with other women skilled in that practice, as discussed below.

Margaret wrote little about her familiarity with minerals in the diary. However, she "was busie to dye wooll tell almost diner time" on 30 October $1599 .^{78}$ For a woman who spent much of her time weaving and spinning, this would have been a critical task. In addition to using the plants from her own gardens to dye wool various colors, Lady Hoby would have employed alum as a fixative to ensure those colors did not bleed or stain. ${ }^{79}$

\footnotetext{
${ }^{73}$ Moody, Private Life, 101.

${ }^{74}$ Ibid., 104.

${ }^{75}$ Ibid., 156.

${ }^{76}$ Ibid., 104, n. 183.

${ }^{77}$ On one occasion when Thomas was invited to drink, "he desired them to pardon him, for he would drink but his ordinary." See Moody, Private Life, Appendix 2, 243. For information on that year's harvest, refer to 163 (9 September 1601) and 165 (25-6 September, 30 September and 1 October 1601).

78 Ibid., 32.

${ }^{79}$ See ibid., 32, n. 75 .
} 
Alum, or potassium aluminum sulphate, was a common component in early modern chymical recipes. ${ }^{80}$ Margaret's diary also recounts three rather curious visits from a goldsmith during the summer of 1600. On 13 June, she purchased "some thing" from him. Two weeks later, he "brought me home some thinge I had to mend", and she met with him a final time the following month. ${ }^{81}$ It appears that he repaired an item of hers and returned it at their second meeting. The precise nature and significance of these exchanges is unclear given Margaret's usual economy with words, but their presence in a spiritually dominated account is unusual and striking.

Margaret's diary provides strong evidence that mundane domestic activities gave her access to the chymical realm. Her activities in her closet, garden and kitchen highlight the importance of natural resources and the utility of chymical techniques to early modern everyday life, affirming the Gloria Mundi by situating the philosopher's stone "in all things created by God". ${ }^{82}$ Lady Margaret did not practice chymistry in isolation. By associating with others who shared her interests, she participated in the wider English chymical community.

Margaret Hoby's social circle provides further evidence of her chymical proclivities. As illustrated earlier by their mutual association with the Listers, Mary Sidney Herbert had a closer and more influential relationship with Margaret, her sometime sister-in-law, than has previously been acknowledged. We know little about Margaret's marriage to Thomas Sidney between 1591 and 1595. She certainly maintained ties with the Sidney family after her second husband's death. Robert Sidney attended her wedding to Thomas Hoby, and she dined with his wife Barbara Gamage, who was particularly close

\footnotetext{
${ }^{80}$ For example, alum appears as an ingredient in the 1550 Rosarium Philosophorum, Edward Kelley's The Stone of the Philosophers, John French's book The Art of Distillation (1651), and the Paracelsian tract The Treasure of Treasures for Alchemists (Eng. ed., 1659), as well as a variety of manuscript works like Bernard Trevisan's "Quest for the stone".

${ }^{81}$ Moody, Private Life, 76 (27 June 1600) and 98 (15 July 1600).

${ }^{82}$ See Adam McLean, "The Glory of the World," The Alchemy Website [http://www.levity.com/alchemy/glory1.html, accessed 3 October 2010].
} 
to the countess of Pembroke, on 11 December $1600 .{ }^{83}$ Unfortunately, there are no known records indicating that Margaret visited the Pembrokes either during or after her marriage to Sidney. ${ }^{84}$ We do, however, find evidence that the women had a significant impact on one another's lives.

Religion provided an ideological link between Margaret and Mary. On 9 October 1599 Lady Margaret "read of Babington”, referring to the rigorously Puritan Gervase Babington, then Bishop of Worcester. ${ }^{85}$ In 1581 and possibly part of 1582, Babington had served as chaplain to Henry Herbert and his third wife at Wilton House. ${ }^{86}$ He maintained a close relationship with the couple until his death in 1610 and may have encouraged Mary Sidney Herbert to devote her energies to the psalms rather than secular poetry. ${ }^{87}$ That Margaret educated herself through the writings of a prominent Protestant theologian is hardly surprising, and his affiliation with her former sister-in-law could be coincidental. However, the only two extant books bearing Lady Margaret's inscription suggest the countess of Pembroke's influence. ${ }^{88}$ Her signature appears on the title pages of two works by Huguenot apologist Philippe de Mornay; she owned translations of his Doctrine of the Holy Sacrament and A Treatise of the Church, published in 1600 and 1606, respectively. ${ }^{89}$ Both Mary Sidney Herbert and her late brother Philip had previously translated other writings by de Mornay into English. It seems likely that the countess's activities inspired Margaret. Certainly the two women saw eye-to-eye when it came to the divine. As a Protestant in a region populated mostly by Catholic recusants, Lady Hoby stayed abreast of contemporary religious debates as a means of converting the misled, transforming the ostensibly private experience of reading into a social, religious and political action just as

\footnotetext{
${ }^{83}$ Moody, Private Life, 128.

${ }^{84}$ Ibid., 149.

${ }^{85}$ Ibid., 27.

${ }^{86}$ John S. Macauley, “Gervase Babington (1549/50-1610)," ODNB, online edn.

[http://www.oxforddnb.com/view/article/973, accessed 6 May 2010].

${ }^{87}$ Hannay, Phoenix, 134.

${ }^{88}$ Both books are part of the Hackness Church library catalogue, now housed at York Minster Library per Moody, Private Life, xxxii, n. 36.

${ }^{89}$ See ibid., xliii, xlvii.
} 
she transmuted the herbal's content into iatrochemical cures. ${ }^{90}$ Her choice of reading material may have constituted a conscious decision to pursue knowledge actively rather than becoming a "passive recipient of ideas". 91 This idea coheres with Rebecca Laroche's assessment of women's signatures in herbal texts, which signify ownership of the information contained therein as well as "the space between reading... and practice". 92

Mary Sidney Herbert and her husband also provide context for the connection between Lady Hoby and the Thornboroughs, prominent chymists who appear so often in the pages of her diary. John Thornborough, like Gervase Babington, was employed by the second earl of Pembroke as chaplain in the mid-to-late 1570 s. $^{93}$ A Salisbury man and recent graduate of Oxford, where he had patronized the notorious chymical healer and magus Simon Forman, Thornborough would have been present at Wilton House when Pembroke married his third wife in $1577 .{ }^{94}$ Like Babington, he could have swiftly grown acquainted with the learned young countess and her spiritual views; it seems likely that Mary introduced him to Margaret during the younger woman's marriage to Thomas Sidney. The queen, whose chymical interests have been discussed at length, joined the Pembrokes in bestowing significant favor upon Thornborough, first as her chaplain-inordinary. He had gained Elizabeth's support in 1588 by bringing "that concealed land of the Dacres to her majesty's receipts of exchequer". ${ }^{95}$ He was hardly a typical man of God. At a time when the monarchy did not look favorably upon married bishops, he took a second wife though his first, Elizabeth Bold, was still living. They likely divorced on the grounds of Bold's infidelity in 1594 or 1595; because divorce was then akin to little more

\footnotetext{
${ }^{90}$ See Julie Crawford, “Reconsidering Early Modern Women's Reading, or, How Margaret Hoby Read Her de Mornay" in The Huntington Library Quarterly, Vol. 73, No. 2 (2010): 193-223, esp. 195 and 208.

${ }^{91}$ Ibid., 201.

92 Laroche, Medical Authority, 72.

${ }^{93}$ Brett Usher, "John Thornborough (1551?-1641)," ODNB, online edn. [http://www.oxforddnb.com/view/article/27339, accessed 5 May 2010].

${ }^{94}$ James Orchard Halliwell, ed., The autobiography and personal diary of Dr. Simon Forman (London, 1849), 12-3.

${ }^{95}$ Usher, "John Thornborough," ODNB. See BL: Lansdowne MS. 74, fol. 32r.
} 
than judicial separation, this would have been a scandal of the first order. ${ }^{96} \mathrm{He}$ evidently had the queen's support in this matter, though his new wife was rumored to be pregnant. The relationship between the Thornboroughs and Queen Elizabeth, herself a keen chymist, warrants further examination. That the monarch continued to favor him in spite of what by most standards would be considered egregious errors in judgment - he even preached her final accession day sermon in 1602 - suggests a real affinity between the two.

By the time of Margaret's diary, Thornborough was Dean of York and Bishop of Limerick. Later, through the patronage of Mary Sidney Herbert's eldest son, William, and the backing of King James I, he would become Bishop of Worcester, again following in Babington's footsteps. The bishop and his second wife, Elizabeth Bayles, are the only non-family or -household members to play such prominent roles in the diary. Indeed, apart from the local minister, Mr. Rhodes, Margaret's physicians and Mr. Hoby himself, they garnered more mentions than anyone else. Most of these visits took place while the Hobys were in London, though the first meeting occurred in York on 25 September $1600 .{ }^{97}$

Margaret and Mrs. Thornborough clearly shared much in common beyond the spiritual realm. Their conversations were not limited to religious matters; Margaret once recorded her resulting guilt when "Mrs Thornborowe Came, and with [her] I had talke of litle purpose". ${ }^{98}$ The mutual affection between them is apparent in their frequent meetings and evidence that Mrs. Thornborough was a doting friend. In the entry dated 22 December 1600, Margaret noted that on "[t]he $23.24: 25$ et 26 : daies I was not well of a great Colde, so that I kept my chamber and went not in to my clositt, and was visited by Mrs Thornborowe euerie day". ${ }^{99}$ She offered more than the simple comfort of friendship and well wishes; just days earlier Margaret recorded the following: "I dined and with vs my

\footnotetext{
${ }^{96}$ Ibid. See TNA: PRO, SP 12/270/75.

${ }^{97}$ Moody, Private Life, 114. See, in 1600, 25 September, 26 November, 5-6, 10, 12-13, 15, 17-22, 29-30

December; in 1601, 2, 5, 13-15, 17, 19, 21, 23, 26 January, 3-4 October 1601; and 16 August 1602.

${ }^{98}$ Moody, Private Life, 126 (26 November 1600).

${ }^{99}$ Ibid., 132.
} 
lord of limbrick and his wiffe : after, I went $\mathrm{w}^{\text {th }}$ hir to hir howse, wher she made me a medeson". ${ }^{100}$ Cures attributed to both women were later included in The Queens Closet Opened. ${ }^{101}$ It is significant that Lady Hoby's closest friend also practiced iatrochemistry. Elizabeth Bayles Thornborough and her husband were well matched. The Queens Closet Opened also published Thornborough's "admirably curing powder". ${ }^{102}$

Significantly for a man whose wife shared his interests, the bishop accepted female contributions to chymical study. In his 1614 Letter of Chemistry, he addressed Lady Knowles, probably Elizabeth Howard Knollys, as both a potential patron and fellow (if fledgling) chymist: "understanding that you have a desire to spend your howers from greater occasions in distilling waters and extracting tinctures, I thought good to write to your Ladishippe how muche the Lady Alcumy rejoyceth". ${ }^{103}$ He portrayed Knowles as having knocked at the "first and outmost gate" leading to Lady Alcumy, whose desire to maintain her chastity had left her imprisoned. In this description he echoed Trithemius's depiction of Alchymia as a "chaste prostitute" a century earlier. ${ }^{104}$ Despite her chastity, like the Virgin Mary, she had borne offspring, "a faire daughter named Distillation" and an unnamed son with cleansing, curative powers. This encouraging letter suggests that Thornborough would have supported Bayles and Lady Hoby in their chymical pursuits.

In 1621 he commemorated his lifelong interest in chymistry with the publication, in Latin, of Lithotheorikos, a text on the philosopher's stone that revealed his familiarity with ancient and contemporary sources alike. ${ }^{105}$ That a devoted Protestant would forego the vernacular in a printed work testifies to the specialized audience at which it was aimed. Robert Napier, under the guise of "R.N.E. Gentleman", acknowledged the bishop's

\footnotetext{
10019 December 1600.

${ }^{101}$ W.M., Queens Closet, 11 ("Lady Hobby”), 267 (“Lady Thornborough”).

102 Ibid., 19.

${ }^{103}$ Quoted in Jayne Archer, "Rudenesse it selfe she doth refine': Elizabeth I as Lady Alchymia” in Goddesses and Queens: The Iconography of Elizabeth I (Manchester: Manchester University Press, 2007): 47. On the identity of Lady Knowles see Archer, "Women and Alchemy in Early Modern England" (PhD dissertation, University of Cambridge, 1999): 3.ii.

${ }^{104}$ Johannes Trithemius, Annales Hirsaugienses, Vol. 2 (Leiden, 1690): 53. Originally published in 1514.

${ }^{105}$ Usher, "John Thornborough," ODNB.
} 
expertise when he dedicated his 1623 translation of Giovanni Baptista Agnello's $A$ reuelation of the secret spirit of Alchymie to Thornborough. ${ }^{106}$ After alluding to Michael Maier's emblematic Atalanta fugiens (1617), Napier described Thornborough as having "so noble a mind, that it dwelleth rather in an heauenly Palace, than an earthly body", situating chymical wisdom between the terrestrial and celestial spheres. ${ }^{107}$ The bishop's knowledge of "our most rare secrets", he claimed, identifying himself as an adept, aimed at both profit and, like Margaret Hoby's charitable medical practice, "the health of man". That same year Robert Fludd dedicated his mystical Anatomiae Amphitheatrum to Thornborough, his "singular friend, most studious in accurately inquiring into the mysteries of nature, in whom is the true light of the world, and the treasure of treasures". ${ }^{108}$ Fludd, too, supported the active participation of women in the Great Work, citing Maria the Jewess and Perenelle Flamel. ${ }^{109}$

Years later, after his second wife's death but more than a decade before his own, Thornborough designed for himself a remarkable tomb that can still be viewed in Worcester Cathedral. This unusual monument is "decorated with obscure mottoes and astrological symbols rather than scriptural texts." spero", a reference to the bellows that stoked the fire in a chymical furnace. ${ }^{111}$ This fire evidently burned throughout the bishop's life and may have inspired the iatrochemistry his wife and Lady Margaret practiced.

\footnotetext{
${ }^{106}$ Giovanni Baptista Agnello, A reuelation of the secret spirit of Alchymie (London: Iohn Haviland, 1623): Epistle Dedicatory.

${ }^{107}$ On Maier's Atalanta fugiens, see Adam McLean, "Atalanta fugiens," The Alchemy Website [http://www.alchemywebsite.com/atalanta.html, accessed 3 October 2010].

${ }^{108}$ Translation quoted in William H. Huffman, Robert Fludd and the End of the Renaissance (London: Routledge, 1988), 32.

${ }^{109}$ See C.H. Josten, "Truth's Golden Harrow: An Unpublished Alchemical Treatise by Robert Fludd" in Ambix, Vol. 3, Nos. 3/4 (1949): 91-150, esp. 147-8.

${ }^{110}$ Usher, "John Thornborough," ODNB.

111 "While I blow, I hope". See Lyndy Abraham, Dictionary of Alchemical Imagery, Cambridge University Press (Cambridge: 1998): 22.
} 
It is difficult to determine Margaret Hoby's place in the history of English chymistry. Her diary is filled with tantalizing hints: homemade salves, aqua vitae and less specific medicines and distillations. My research suggests that she came to the subject indirectly, through the spiritual beliefs she shared with family members, such as Mary Sidney Herbert, and friends like the Thornboroughs. In her efforts to assist others by doing God's will, Margaret discovered her own aptitude for healing. For a woman who already spent a great deal of time preoccupied with her own health and well-being, it made sense to extend those discussions with her physician, whose services few others in the area could afford, to the larger community. Furthermore, in doing charitable work, her services did not compete with those of the authorities from whom she sought counsel, thus contributing to a positive relationship with the medical community.

Her interest in distillation was utilitarian in nature, employing chymistry to produce medicaments, balms, oils and fixatives for wool-dyeing. She certainly would not have boasted the same level of familiarity with chymical literature as John Thornborough; in contrast, Margaret's activities were informed by the humble herbal, letters of advice from her own doctor and handbooks of the day aimed at gentlewomen, combining cookery and physic in an accurate reflection of a lady's everyday responsibilities. ${ }^{112}$ Her childless state, which she may have considered a sign from God that she had failed to achieve the primary goal of marriage, may also have influenced these activities. Though she never gave birth, Lady Margaret's role in Hackness was undeniably maternal, analogous to Queen Elizabeth's nurturing relation to her subjects. We know that, like her childhood mentor Katherine Hastings, she took in relatives, young charges and elderly widows in addition to providing medical services for her household and local community. By caring for these people for whom she was, to varying degrees, responsible, she emphasized her motherly

\footnotetext{
112 These books became particularly popular in the middle of the seventeenth century, but Margaret may have been familiar with A Treasury of Hidden Secrets (1573) by John Partridge, Thomas Dawson's The Good Husvvifes ievvall (1587), the anonymous Good Huswifes Handmaide (1594) and Sir Hugh Plat's Delights for Ladies (1600).
} 
position as female head of a large estate. Her use of iatrochemistry thus granted her relief as she comforted her patients. 
Figure 3: Gentlewomen Chymists and the Courtly Chymical Community

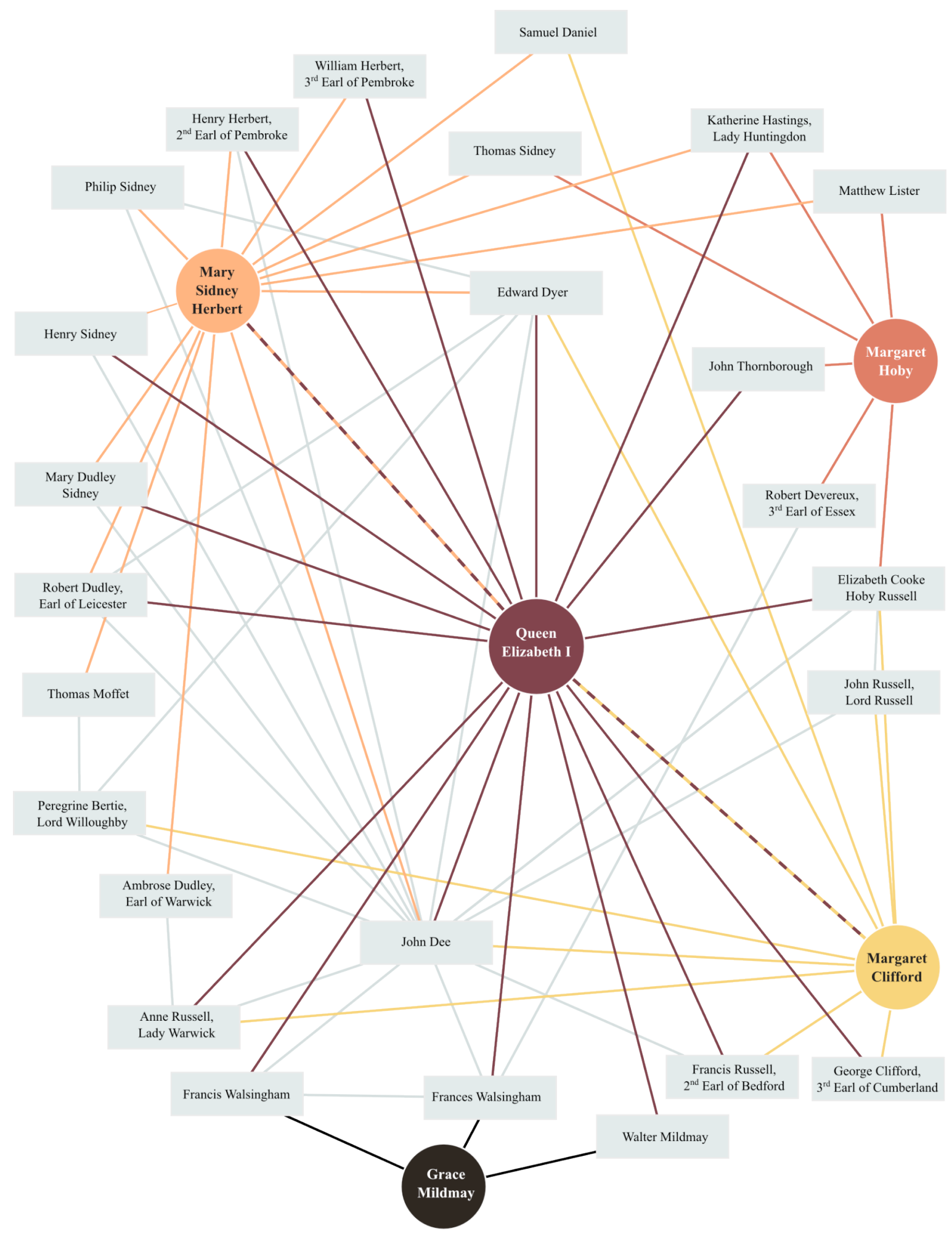

Compiled by Sienna Latham and Chris McDowall (2010). 


\section{Chapter 5}

\section{Margaret Clifford and the Elizabethan Chymical Community}

The life of Margaret Clifford (1560-1616), countess of Cumberland, illuminates the critical importance of community in cultivating chymical knowledge. Her familial connections, friendships and patronage form the context for her reputation as a gifted chymist and healer. Those who knew her best portrayed the countess as a pious, virtuous and strong-willed woman who cared deeply for others. Margaret's sole surviving autobiographical writing, a poignant letter to her chaplain, Dr. Layfield, confirms this impression. Exposed from a young age to chymical texts through familial connections, her life was characterized by a desire to know and better understand the natural world. This inquisitiveness led her from iatrochemistry to more esoteric aspects of chymical study. Like other gentlewomen of the era, Lady Margaret practiced charitable medicine. In contrast to most, however, her understanding of the human body drew from occult principles. As a soror mystica she stretched the limits of acceptable female chymical practice and contributed to the changing nature of chymistry in early modern England.

This chapter contributes to historiography on Margaret Clifford and female chymical participation by drawing attention to the links between the Russell, Clifford, Sidney, Dudley, Herbert, Hoby and, to a lesser extent, Mildmay families. While others have studied and acknowledged the role of chymistry in each family's individual history, until now no one has explored the many connections between them in the context of their chymical and metallurgical activities. These familial and social links are particularly important in light of the Elizabethan court's preoccupation with transmutation. That all of these families possessed significant connections to both the queen and known chymists points to a vital knowledge-sharing practice among the wider English chymical community (Figure 3). I take a roughly chronological approach in documenting these complex 
relationships, with Lady Margaret Clifford's chymical lineage, friendships and manuscript receipts forming the heart of the chapter.

Margaret Russell was born into a chymically inclined family on 7 July 1560 . Just two years earlier William Ward had dedicated his English translation of Alexis of Piedmont's Secrets, one of the most popular and influential sixteenth-century books of secrets, to her father, Francis Russell, second Earl of Bedford. ${ }^{1}$ These texts compiled medicinal, technical and magical recipes with practical value. Ward accordingly focused on the utility of God's creation when addressing his opening epistle to the earl. The creator had, after all, provided mankind with

herbes, trees, fruites, stones, rootes, waters, Iron, tinne, leade: yea, and the dewe of the ayre, so that nothing is unprofitable, no not the very dunge of beasts, and byrdes, but that it hath some wholesome operation for mans health. In al these thing[s] are certain secret vertues, which be manifest signes of gods love and favoure towards man: for he created them to the intent that men shoulde use them, glorifie him, and give hym thankes for them. ${ }^{2}$

Dedications did not necessarily imply a relationship between writer and recipient, and Ward approached Bedford with typical hyperbole. Still, his request for patronage may have been welcomed. Ward took his MA in 1558 - the same year this translation was printed. As a fellow of King's College, Cambridge he would subsequently proceed to the MD, and in later life became Regius Professor of Physic. ${ }^{3}$ Even in youth this medical man

\footnotetext{
1 "Alexis of Piedment" is believed to be a pseudonym of Italian chymist Girolamo Ruscelli. William C. Eamon, Books of Secrets and the Empirical Foundations of English Natural Philosophy, 1550-1660 (Ann Arbor: University Microfilms International, 1986): 79; Eamon, "Arcana Disclosed: The Advent of Printing, the Books of Secrets Tradition and the Development of Experimental Science in the Sixteenth Century," History of Science, Vol. 22 (1984): 124-5; Eamon, Science and the Secrets of Nature: Books of Secrets in Medieval and Early Modern Culture (Princeton: Princeton University Press, 1994): 134.

${ }^{2}$ Girolamo Ruscelli, The secretes of the reuerend Maister Alexis of Piemont (London, 1558): Epistle. Ward's translation was printed in four parts, this being the first. Emphasis mine. In addition to fertilizer, "the very dunge of beasts" was also a component of many chymical experiments.

${ }^{3}$ Sir Humphry Davy Rolleston, The Cambridge Medical School: A Biographical History (Cambridge:

Cambridge University Press, 1932): 137-8.
} 
believed "they that despise Phisicke, dispise a heavenlye science". ${ }^{4}$ He trusted that Francis Russell shared his conviction in the undeniable connection between faith and medicine.

Religion informed many aspects of Bedford's life — as well as those of his family members. In 1559 Russell's daughter Anne, the queen's maid of honor, married Mary Sidney Herbert's uncle Ambrose Dudley and became the countess of Warwick. This alliance with the emphatically Protestant Dudley and Sidney families persisted, as Lady Warwick would later bequeath land to Robert Sidney. She also maintained a close relationship with her Puritan sister-in-law, Katherine Hastings, who educated Margaret Dakins (later Hoby). A committed Protestant, Bedford had no qualms about sending his youngest daughter to the Catholic stronghold of Yorkshire to advance the reformed religion and cement a political alliance. At sixteen Margaret married her father's former ward, George Clifford, third earl of Cumberland (1558-1605). Though he had been raised Catholic, twelve-year-old George joined the Russells in Hertfordshire upon his father's death in 1570; the two earls had already negotiated his betrothal to one of the Russell girls, making Bedford's guardianship a logical choice. ${ }^{5}$

Margaret and George wed on 24 June 1577 in the presence of the queen, but their marriage soon became troubled. ${ }^{6}$ The couple's sons both died in childhood, and George ran up large gambling debts, fathered at least two illegitimate children, and became estranged from his wife and daughter. ${ }^{7}$ While he developed a reputation as Elizabeth's "rogue" courtier and champion, as well as a capable privateer, Lady Margaret remained isolated at Skipton Castle, surrounded by northerners whose religious beliefs ran counter to her own firm Protestantism. "I was separated from all I knew", she wrote to Dr. Layfield,

\footnotetext{
${ }^{4}$ Ruscelli, The secretes, Epistle.

${ }^{5}$ Peter Holmes, "George Clifford (1558-1605)," ODNB, online edn. [http://www.oxforddnb.com/view/article/5645, accessed 10 May 2010].

${ }^{6}$ Early letters do indicate affection between the two. George Williamson, Lady Anne Clifford Countess of Dorset, Pembroke and Montgomery, 1590-1676 (Kendal: Titus Wilson and Son, 1922): 25-6.

${ }^{7}$ Ibid.
} 
“in a country contrary to my religion... and I with thought grew almost continually sick, looking as a ghost that wanted the soul of comfort". As we saw in Margaret Hoby's case, this connection between faith and illness — and, therefore, medicine - would impact her life significantly.

Lady Cumberland soon discovered that she had married into another chymically minded family. Her late father-in-law spent his final years preoccupied with printed and manuscript works on the subject, and experimented with alchemy and distillation, according to Margaret's daughter Anne (1590-1676), who left abundant autobiographical writings. ${ }^{9}$ Since she never knew her grandfather, this information must have come from her father or some other household member. The tenth Lord Clifford (c. 1455-1523) also shared these interests. An eighteenth-century catalogue of the castle library includes numerous chymical books and manuscripts, supporting Anne's claims. These included "An old book of Chemistry and Alchimy, no title, unbound... The practise of the Great work etc. by [Philippi a Rovillasco,] the Monk of berye...Another book of Alchimy entituled a Dialogue between Nature and a Disciple of Philosophie... [and] Part of a very old, imperfect Manuscript of Alchimy". ${ }^{10}$ With such resources available to her, Lady Margaret's interest in chymistry naturally deepened.

We gain a clearer picture of the countess through her daughter's writings. Anne characterized her mother as virtuous and determined, an inveterate student with "a discerning spirit, both into the disposition of humane creatures and natural causes, and into the affairs of the world...For though she had no language but her own, yet was there few books of worth translated into English but she read them, whereby that excellent mind of

\footnotetext{
${ }^{8}$ G.C. Williamson, George, Third Earl of Cumberland (1558-1605): His Life and His Voyages (Cambridge: Cambridge University Press, 1920): 286.

9 J.P. Gilson, Lives of Lady Anne Clifford Countess of Dorset, Pembroke and Montgomery (1590-1676) and of Her Parents Summarized by Herself (London: The Roxburghe Club, 1916): xxii; R.T. Spence, Lady Anne Clifford, Countess of Pembroke, Dorset and Montgomery (1590-1676) (Thrupp: Sutton Publishing, 1997): 257.

${ }^{10}$ A Catalogue of the Books in the Closset in the Passage Room next the Pantry in Skipton Castle, 28th August, 1739, Yorkshire Archaeological Society, DD121/111. See also Spence, Lady Anne Clifford, Appendix II, 257.
} 
her was much enriched". ${ }^{11}$ The eighteen spiritual and poetic works dedicated to her indicate that Anne was not alone in this opinion. ${ }^{12}$ Though Lady Margaret's interests were wide-ranging, in her hagiography Anne emphasized two aspects of her mother's life: chymistry and religion. The countess

was a lover of the Study and practice of Alchimy, by which she found out excellent Medicines, that did much good to many; she delighted in the Distilling of waters, and other Chymical extractions, for she had some knowledge in most kinds of Minerals, herbs, flowers and plants...[She] was truly religious, devout and conscientious, even from her very childhood, and did spend much time in reading the Scriptures and other good books, and in heavenly meditations and in prayers, fastings, and deeds of charity. ${ }^{13}$

Lady Margaret's daily routine possibly resembled those of Margaret Hoby and Grace Mildmay. Anne's words suggest a significant connection between the "excellent Medicines" and "deeds of charity", echoing the activities of the other two gentlewomen. Additionally, like Mary Mildmay, it appears that she more than approved of her mother's chymical skills - she took great pride in them. Her tendency to embrace a somewhat mystical view of Lady Margaret is worth noting. This stemmed from a prophetic dream the countess had prior to Anne's birth, accurately predicting that she would outlive her brothers and inherit the Clifford lands. Anne later interpreted such powers as evidence that her mother "had more converse with heaven and heavenly contemplations than with terrene and earthly matters". ${ }^{14}$ Success in chymical experiments and charitable healing would have served to reinforce this conviction, as did her role in spreading Protestant beliefs in Yorkshire. Even Beamsley Hospital, the almshouse she founded for local widows in 1593, drew architectural inspiration from round churches. ${ }^{15}$

\footnotetext{
${ }^{11}$ Gilson, Lives of Lady Anne, 19-20.

${ }^{12}$ See Franklin B. Williams, Jr., Index of Dedications and Commendatory Verses in English Books Before 1641 (London: Bibliographical Society, 1962): 40.

${ }^{13}$ Gilson, Lives of Lady Anne, 19-20.

${ }^{14}$ J.H. Wiffen, Historical Memoirs of the House of Russell from the Time of the Norman Conquest, Vol. 2 (London: Longman, Rees, Orme, Brown, Green, and Longman, 1833): 9. See also Barbara Kiefer Lewalski, Writing Women in Jacobean England (Cambridge: Harvard University Press, 1993): 136.

${ }^{15}$ Spence, "Margaret Clifford," ODNB.
} 
Like her familial relations, Lady Margaret Clifford's friendships reveal the significant role chymistry played in her life. Her affiliation with the magus John Dee may have begun quite early. Dee recorded a 1577 visit from her father, a privy councilor and Knight of the Garter, in his diary: "Jan. 22nd, The Erle of Bedford cam to my howse". ${ }^{16}$ He may have been seeking advice regarding his godson Francis Drake's upcoming sea voyage. ${ }^{17}$ The presence of Lady Margaret's nativity in the diary presents an alternative reason; Bedford could have had his youngest daughter's forthcoming nuptials in mind and instead sought the expertise of the queen's own trusted astrologer. ${ }^{18}$ Margaret was listed, curiously, with both her maiden name and married title, a combination that would have been most logical in the months prior to her wedding. Bedford may have commissioned Dee to cast a questionary horoscope based on Margaret's estimated conception or birth. He was not the only Russell who traveled to Mortlake. Lady Margaret's elder brother John, Lord Russell, accompanied the Polish Prince Albrecht Laski, Philip Sidney and other gentlemen to Dee's home on the afternoon of 15 June 1583. Russell's wife was Margaret Hoby’s learned mother-in-law, Elizabeth Cooke, who consulted Dee regarding the midnight theft of “perles, diamands, \&c." in 1591. ${ }^{19}$ Margaret and John's sister, Lady Warwick, furthermore acted as sympathetic intermediary between the magus and Queen Elizabeth in the early-to-mid-1590s. ${ }^{20}$

Margaret's interest in mineral extraction and metallurgical ventures was related to, if not motivated by, chymical activities. ${ }^{21}$ The countess invested in lead-mining, ironsmelting and the East India Company. ${ }^{22}$ In September of 1589 she and the courtier

\footnotetext{
${ }^{16}$ John Dee, The Private Diary of Dr. John Dee, ed. James Orchard Halliwell (London, 1842), 3.

${ }^{17}$ Penny Bayer, "Lady Margaret Clifford's Alchemical Receipt Book and the John Dee Circle" in Ambix, Vol. 52, No. 3 (2005): 281.

${ }^{18}$ Dee, The Private Diary, 1.

19 Ibid., 40.

${ }^{20}$ Ibid., 1.

${ }^{21}$ Richard T. Spence, Lady Anne Clifford, 8. See also Spence, "Mining and Smelting in Yorkshire by the Cliffords, Earls of Cumberland, in the Tudor and Early Stuart Period" in Yorkshire Archaeological Journal, Vol. 64 (1992): 162.

${ }^{22}$ See Richard T. Spence. "Margaret Clifford (1560-1616)," ODNB, online edn. [http://www.oxforddnb.com/view/article/5655, accessed 11 November 2009].
} 
Richard Cavendish (c. 1530-1601) signed a twenty-one-year lease of mines between Glusburn and Cononley, an area several miles south of Skipton Castle colloquially known as Gib Moor. They may have extended the lead-mining area in the region, but little evidence survives about the hundred-acre operation's success. ${ }^{23}$ Lady Margaret's connection to Cavendish deserves greater attention.

Despite his reputation as a mathematician with twenty-eight years of university study to his credit, reliable details about Richard Cavendish's life continue to elude historians. A follower of the earl of Leicester, he published a work of Protestant apologetics in 1571, received a mining patent two years later and served as MP for Denbigh. $^{24}$ The queen and Lord Burghley, known for their chymical patronage, were favorably disposed toward Cavendish. ${ }^{25}$ One of his daughters married geographer Richard Hakluyt, who dedicated his first book to Philip Sidney, but this association, too, yields little information. Following Cavendish's death, Lady Margaret penned an epitaph in honor of her former business partner, who had been "Grac' $d$ with the graces Muses and the Artes". ${ }^{26}$ Her connections to poets Edmund Spenser, Aemilia Lanyer and Samuel Daniel suggest a strong interest in poetry, but this short verse is the only one written by the countess known to have survived.

Like Lady Margaret and her relations, Richard "Candish" associated with John Dee and the courtly chymical community. He first came to Mortlake on 18 May 1590, accompanied by his "most famous" nephew Thomas, a circumnavigator who may have wished to discuss navigation. ${ }^{27}$ Seven additional entries that year refer to Richard or Mr. Candish, who offered financial assistance to Dee and attempted to secure the provostship

\footnotetext{
${ }^{23}$ Spence, "Mining and Smelting in Yorkshire," 167-8.

24 Ibid.

${ }^{25}$ See, for instance, James Stuart Campbell, "The Alchemical Patronage of Sir William Cecil, Lord Burghley," (Master's thesis, Victoria University of Wellington, 2009); Glyn Parry, The Arch-Conjuror of England: John Dee and Magic at the Courts of Renaissance Europe (New Haven: Yale University Press, forthcoming 2010).

${ }^{26}$ Jane Stevenson and Peter Davidson, Early Modern Women Poets (1520-1700): An Anthology (Oxford: Oxford University Press, 2001): 84.

${ }^{27}$ Dee dreamt of a "Mr. Candish" on 10 September 1579, but may have been referring to a different man. See Dee, The Private Diary, 6.
} 
of Eton for him. Cavendish evidently served a similar role to that of Lady Warwick in mediating between Dee and the queen. ${ }^{28}$ On 16 December, Cavendish "received from the Quene's Majestie warrant by word of mowth to assure me to do what I wold in philosophie and alchimie, and none shold chek, control, or molest me". ${ }^{29}$ The most significant entry finds Dee bestowing upon Cavendish — following a vow of secrecy — "the copy of Paracelsus twelve lettres, written in French with my own hand". ${ }^{30}$ The magus took elaborate precautions to exaggerate the manuscript's importance and ensure his friend would deliver this gift directly to the queen. Dee's willingness to part with a work that he had taken the time to copy himself indicates that he respected and trusted Cavendish's chymical skills. Taken in conjunction with the message from Elizabeth, it suggests furthermore that Cavendish's fascination with chymistry matched his engagement with the English chymical community.

Margaret also appeared several times in Dee's diary. On 25 October 1593 he observed, perhaps with some surprise, her preacher Mr. Gray’s “wrangling and denying and despising alchimicall philosophers". ${ }^{31}$ As a family friend and keen practitioner himself, he would surely have been aware of the countess of Cumberland's interest in the subject. In early December Lady Margaret herself, accompanied by two other gentlewomen, visited Dee. A week earlier she had sent "John" to Mortlake, perhaps to arrange her own visit. He may have been John Davis, Lord Cumberland's servant who had removed books from Dee's library after the magus departed for Poland with Laski in 1583, though relations had since been restored. ${ }^{32}$ In 1595 Dee named the countess godmother alongside Frances Walsingham, countess of Essex, wife of the late Philip Sidney and now married to Robert Devereux — to his daughter Margarite, though in keeping with

\footnotetext{
${ }^{28}$ Ibid, 33-7. See entries of 29/30 May, 24 June, 31 July, 28 November, 2 December, 4 December and 16 December.

${ }^{29}$ Ibid., 37.

${ }^{30}$ Ibid., 35 (31 July 1590).

${ }^{31}$ Ibid., 47.

${ }^{32}$ Bayer, "Lady Margaret," 283.
} 
contemporary custom Mistress Davis served in her stead. ${ }^{33}$ Dee may have hoped that young Margarite would, like her namesake, count chymistry amongst her many pursuits. Another chymist whom both Lady Margaret and John Dee knew well was Peregrine Bertie, Lord Willoughby (1555-1601). A strenuous Protestant like his parents, Bertie had been educated in the household of William Cecil, who may have passed on his interest in chymistry. Cecil's influence also gained Bertie recognition from the queen, for whom he undertook a variety of diplomatic missions. He traveled to Denmark as Elizabeth's representative twice during the 1580s. Willoughby's interest in natural philosophy led him to frequent astronomer and chymist Tycho Brahe's laboratory during his time in Copenhagen. ${ }^{34}$ Thomas Moffet, who would later serve as Mary Sidney Herbert's physician, accompanied him on his first stay in Denmark in 1582, eager to meet with the influential Paracelsian Petrus Severinus. ${ }^{35}$ In 1585 Moffet began work on a layman's manual of Hippocratic advice at Willoughby's request. Though not published until 1588, the Nosomantica Hippocratea targeted Willoughby's peers in the House of Lords. Moffet hoped that more noblemen would study medical matters, claiming that "Mars has need of the Muses". ${ }^{36}$

After an effective but exhausting military career in the Netherlands and France, where he served alongside close friends Philip Sidney and the earl of Leicester, Willoughby spent years trying to improve his health in continental spa towns. In 1598 he became governor of Berwick. We find evidence of his friendship with Lady Margaret and confirmation of their shared chymical knowledge — during these final years of his life. In four letters he wrote to the countess at the turn of the seventeenth century,

\footnotetext{
${ }^{33}$ Dee, The Private Diary, 47, 53.

${ }^{34}$ D.J.B. Trim, "Peregrine Bertie (1555-1601)," ODNB, online edn. [http://www.oxforddnb.com/view/article/2275, accessed 21 June 2010].

${ }^{35}$ V.H. Houliston, "Sleepers Awake: Thomas Moffet's Challenge to the College of Physicians of London, 1584," Medical History, Vol. 33 (1989): 237.

${ }^{36}$ Ibid., 242. A fitting reference to Willoughby's military service, which would inspire ballads.
} 
Willoughby drew parallels between his ailing body and Lady Margaret's marital

discord. ${ }^{37}$ George Clifford's infidelities seem to have been common knowledge by 1599 , when Samuel Daniel dedicated his A Letter from Octavia to Marcus Antonius to the countess, a "great afflicted Lady". ${ }^{38}$ In one letter Willoughby described her correspondence as "leafe gold to my hart". ${ }^{39}$ He bemoaned the absence of winds powerful enough to blow her north, or him south. Their friendship clearly served as a balm at a time when he knew death would soon be at his door.

More significantly for our purposes, Willoughby addressed Margaret as a "noble phylosophying lady". He claimed she had "learned the art of separation, to draw $y^{\mathrm{e}}$ spirit from $\mathrm{y}^{\mathrm{e}}$ body to add it to it agayne, things dead to live, livinge things apparent dead, yet having in concealed beinge a multiplied life". ${ }^{40}$ In contrast to "natures effects", Margaret's experiments were "wisdoms works, of a lytle red sand to make a great deale of gold". Willoughby placed her in a long line of sages with whom he assumed she was familiar, following in the footsteps of Hermes, Solomon, Ripley and, most recently, Dee's more successful associate, Edward Kelley:

And now comes my La: of Cumberland knowinge how of dissolued putrefied bodies no good can be lokd for $\mathrm{w}^{\text {th }}$ out sublimatinge. She brings a dead body into $y^{\mathrm{e}}$ Alembic head of fine conceite, then disgests \& reuiues it, and lastly proiects that rectified oyle of Gratiounes upon an old bowed plate of Saturne, and by her artifice makes $y^{e}$ old mans selfe beleaue he is not metall mutch inferiour to his grandchild Sol. Praise geving lady, All praises duely return to you as water to $\mathrm{y}^{\mathrm{e}}$ mother Sea...

This elaborate metaphor depicts the countess chymically sublimating his diseased body through her kindness. Despite the miles separating Skipton and Berwick, Lady Margaret may have undertaken iatrochemical experiments to improve and prolong her friend's life.

\footnotetext{
${ }^{37}$ Cumbria Record Office, Kendal, WD/Hoth/Box 44.

${ }^{38}$ Samuel Daniel, "A Letter from Octavia to Marcus Antonius" in The poeticall essayes of Sam. Danyel (London, 1599). Willoughby alluded to this in one of his letters: "Octavia a ritch clasped boke wherein the secrets of all good wifery is contained" (Kendal, Cumbria Record Office, WD/Hoth/Box 44/4b).

${ }^{39}$ Cumbria Record Office, Kendal, WD/Hoth/Box 44/2a.

${ }^{40}$ Cumbria Record Office, Kendal, WD/Hoth/Box 44/4a.

${ }^{41}$ Ibid.
} 
However, Willoughby's letters attest to the fact that they had not seen each other recently. Any chymical discussions in the late 1590 s took place only in writing.

By returning to John Dee's diary, we find evidence that Lady Margaret's chymical alliance with Lord Willoughby began years earlier. Willoughby dined at Mortlake on 3 December 1593 , the same day the countess visited Dee. ${ }^{42}$ On the previous day the magus had rather cryptically noted "the Lord Willowghby his bowntifull promys to me". That he described some kind of chymical knowledge or creation seems reasonable; Willoughby's letter to Margaret emphasized chymistry's chrysopoetic aims, which certainly had bounty in mind. Margaret's sister, the countess of Warwick, had recently helped Dee to regain the queen's favor, and the magus eagerly cultivated courtiers to help resurrect his career. ${ }^{43}$ Like Cavendish, Willoughby helped the Dees financially, and it appears he also consulted Dee in his capacity as an astrologer. Lord Willoughby's fraternity with the Dee circle provides much-needed context for the chymical manuscript, rediscovered by biographer George Williamson in the Muniment Room at Skipton Castle, that belonged to the countess of Cumberland. ${ }^{44}$

The manuscript compilation of chymical receipts associated with Margaret Clifford sheds light on her chymical contacts. Penny Bayer's impressive 2005 article first analyzed this 138 -folio quarto volume. Like her I refer to the bound manuscript, titled "Receipts of Lady Margaret Wife of George, 3rd Earl of Cumberland for Elixirs, Tinctures, Electuaries, Cordials, Waters, etc., MS circa (1550) with Her Annotations", more concisely as "The Margaret Manuscript". ${ }^{45}$ After examining the evidence for the manuscript's links to both Clifford and John Dee, Bayer suggested that the vicar of Bradford, Christopher Tailor, compiled the receipts for Lady Margaret by liaising with members of Dee's circle. My

\footnotetext{
${ }^{42}$ Dee, The Private Diary, 47. Willoughby also appears on 1 (nativity) and 51.

${ }^{43}$ See Parry, Arch-Conjuror, Chs. 19, 20.

${ }^{44}$ Williamson, Lady Anne Clifford, 339, n. 5.

${ }^{45}$ Cumbria Record Office, Kendal, WD/Hoth/A988/5, henceforth referenced as "The Margaret Manuscript."
} 
research indicates that, although a Christopher Taylour wrote the bulk of "The

Margaret Manuscript", as supported by the presence of his name and initialed "CT" throughout, he could not have been the vicar Bayer proposed. ${ }^{46}$ Furthermore, the receipts were not copied for Clifford; she acquired the manuscript later through a mutual friend.

The question of how "The Margaret Manuscript" wound up in Margaret Clifford's library may be answered by the company she and its authors kept. Those writers require further examination.

“The Margaret Manuscript" features two primary hands, neither of which matches Clifford's own writing when compared to extant letters. ${ }^{47}$ Hand A, which opens the volume and has been dated stylistically to the mid-sixteenth century, can be found on folios $1 \mathrm{r}$ to $5 \mathrm{r}, 77 \mathrm{r}$ to $95 \mathrm{v}$ and $137 \mathrm{r}$ to $138 \mathrm{r} .^{48}$ Hand $\mathrm{B}$ can be dated to 1598 at the earliest, and composes the bulk of the manuscript: folios $5 \mathrm{r}$ to $32 \mathrm{r}, 35 \mathrm{r}$ to $67 \mathrm{r}, 95 \mathrm{v}$ to $98 \mathrm{v}, 107 \mathrm{r}$ to $130 \mathrm{r}, 133 \mathrm{r}$ to $133 \mathrm{v}$ and $135 \mathrm{v} .^{49}$ Italic annotations, consistent with the recipe headers as well as proper names in Hand B, appear on pages written by both scribes. ${ }^{50}$ Scribe B therefore appears to have compiled the manuscript. The annotating hand occasionally wrote in Latin, suggesting that it could not have been the work of Lady Margaret, who, as her daughter declared, "had no language but her own".51 Bayer correctly hypothesized that Hand B belonged to the chymist Christopher Taylour, citing similarities with writing purported to be his and the presence of hands similar to both A and B in other manuscripts

\footnotetext{
${ }^{46}$ See "The Margaret Manuscript," fol. 77r. Forty-six different pages spanning the manuscript include "CT", which occasionally appears multiple times on a single page. It seems to act as a kind of validation of the process described in preceding lines, akin to probatum est. There are also large initials "C.T." on fol. 35r. Note that "CT" could be interpreted as "CP".

${ }^{47}$ See Bayer, "Lady Margaret," 272-3, for commentary from a paleographer.

${ }^{48}$ On this last count my analysis marks a departure from Bayer, who listed fols. 137r-138r as written by Scribe B. See Bayer, "Lady Margaret," 272, n.7.

${ }^{49}$ Fol. $35 \mathrm{r}$ is explicitly dated 1598 , and references to books printed in the 1590 s support this time frame. The manuscript contains a number of blank pages. Additionally, there may be more than two hands; the handwriting on fols. $134 \mathrm{r}$ and $135 \mathrm{r}$ resembles but is not identical to Hand $\mathrm{B}$, which itself displays a great deal of variety.

${ }^{50}$ See, for instance, "Alexander A Suchten," fol. 16v, and "Spirite of Salt," fol. 17r.

${ }^{51}$ Gilson, Lives of Lady Anne, 20.
} 
associated with Christopher Taylour. ${ }^{52}$ Taylour owned or wrote a variety of manuscripts, several in the Bodleian Library. ${ }^{53}$ These include the early seventeenthcentury Ashmole MS 1392, which he addressed "to a lady". 54

Bayer relied heavily on the 1598 will of Christopher Tailor, vicar of Bradford, when proposing an identity for Taylour. ${ }^{55}$ Bradford's proximity to Skipton Castle helped to explain the countess's acquisition of the manuscript. Crucially, Tailor left his substantial library to a single son and two daughters. The Christopher Taylour of "The Margaret Manuscript", by contrast, compiled receipts for "my two beloued Sonnes". 56 With manuscripts like this one indicating a chymical culture of shared receipts, we can hypothesize that Margaret Clifford and Christopher Taylour, with their overlapping associates, may very well have known each other. He could have lent the manuscript to the countess, knowing of her interest in chymical matters. Alternatively, Taylour's sons may have declined their inheritance and sold their father's library, perhaps as a result of financial difficulties. Margaret would have been delighted to discover another predominantly English manuscript with so wide a range of receipts.

We know that the Cumberlands employed at least one Taylour: Anne, governess to young Anne Clifford. She appears alongside Samuel Daniel in the 1646 "Great Picture", which I will discuss below. ${ }^{57}$ Born Anne Cholmley in London, she had a number of children with her husband William, but outlived them all. ${ }^{58}$ Christopher, whose identity remains a mystery, may have been William's father, uncle, brother or cousin. In “The Margaret Manuscript" he presented chymistry as an enduring family affair that he had practiced alongside his brothers, Malding and an unnamed sibling. ${ }^{59}$

\footnotetext{
${ }^{52}$ Bayer, "Lady Margaret," 272, esp. n. 10.

${ }^{53}$ Ashmole MSS 1392, 1406, 1447, 1450, 1482 and 1492.

${ }^{54}$ Adam McLean, "Database of alchemical manuscripts - Bodleian - Ashmole," Alchemy Website [http://www.alchemywebsite.com/almss5.html, accessed 20 July 2010].

${ }_{55}$ Bayer, "Lady Margaret," 279-80.

56 "The Margaret Manuscript," fols. 36v and 116v.

${ }^{57}$ Williamson, Lady Anne Clifford, 342.

${ }^{58}$ Ibid., 65.

59 "The Margaret Manuscript," fols. 36v, 41r and 67r.
} 
Attributions in "The Margaret Manuscript" suggest that Taylour, like Lady

Margaret, knew John Dee. A “Treatise of Cachelah" written by Scribe A is known to have circulated among Dee's associates in the $1580 \mathrm{~s}$ and ' $90 \mathrm{~s} .{ }^{60}$ A curious flower-like symbol that appears on five different folios in "The Margaret Manuscript" may provide a more tangible link to Dee, whose name and works are otherwise curiously absent. ${ }^{61}$ He was known to incorporate "flower signs" in his manuscripts, and Jan Bäcklund has suggested that others in Dee's circle embraced such marginalia. ${ }^{62}$ Christopher Taylour may have been one of those chymists.

In referring to his own works as well as the manuscript and print publications he owned, Taylour assumed that the reader either had access to them already or would in the future. He addressed his children directly on several occasions: "And nowe my Sonnes both you haue that matter, $\mathrm{w}^{\text {ch }}$ in manye of my Bookes, pappers \& writings, I haue called by manye names". ${ }^{63}$ With one annotation Taylour exhorted his sons to "[s]tuddye well my ecphrasticall Comentarie vppon Geber, of his Bookes of Alchymie: written by me, And is amongst my bookes". ${ }^{64}$ Thus Taylour instructed them in the use of this intellectual legacy. His words served as a key not only to the general practice of chymistry, but also the more specific cartography of his library.

That chymical library was evidently impressive. "The Margaret Manuscript" refers to at least thirty-seven writers and texts spanning centuries, including works that circulated in print and manuscript form, written in English, Latin, German, French and possibly other languages. ${ }^{65}$ The most frequently mentioned authors were Paracelsus — represented by a dozen different writings —Alexander von Suchten, Gaston Dulco Clavens, Ramon Llull,

\footnotetext{
${ }^{60}$ Lauren Kassell, Medicine and Magic in Elizabethan London: Simon Forman: Astrologer, Alchemist, and Physician (Oxford: Clarendon Press, 2005): 179.

61 "The Margaret Manuscript," fols. 15v, 19v, 25v, 45r, 95v.

${ }^{62}$ Julian Roberts and Andrew G. Watson, John Dee's Library Catalogue of 1583 (London: Bibliographical Society, 1990): 25. Jan Bäcklund, "In the Footsteps of Edward Kelley" in John Dee: Interdisciplinary Studies in English Renaissance Thought, ed. Stephen Clucas (Dordrecht: Springer, 2006): 306.

63 "The Margaret Manuscript," fol. 36v.

${ }^{64}$ Ibid., fol. $43 \mathrm{v}$.

${ }^{65}$ It is unclear whether Taylour read Spanish or Catalan texts.
} 
Philippi a Rovillasco, Blaise de Vigenère, Bernard Trevisan and John Isaac Holland. ${ }^{66}$

Taylour was acquainted with celebrated and obscure chymical texts alike, from George Ripley's Medulla Alchymiae to the lesser known Stella complexionis. Two discussions of the Aureum Vellus, "printed in Duche $\mathrm{w}^{\text {th }}$ picters", confirm a writing date no earlier than 1598, when the first German edition of this allegory was printed in Rorschach am Bodensee. ${ }^{67}$ The recommendation of an "Epistle" by John Pontanus suggests a slightly later date, as his Epistle on the Mineral Fire was first published in Latin in $1600{ }^{68}$ If Taylour's library came into Lady Margaret's possession when she acquired "The Margaret Manuscript", no evidence has emerged. Though she would have been unable to read most of these works, her learned contacts and reputation as a patron doubtless offered avenues for translation.

Many of the sources named in "The Margaret Manuscript" belonged to the circle surrounding Dee and his sometime partner Edward Kelley, indicating a lively receiptsharing culture. For instance, according to Taylour, the poet and courtier Edward Dyer paid "a frenche gentleman" for the aptly named "Opus longum longum" that opens the manuscript. ${ }^{69}$ Edward Kelley's brother Thomas provided three receipts, one of which included corroboration from Dyer. ${ }^{70}$ Kelley himself contributed a cure for epilepsy, “A worcke of the Smerell Stone" and "Mercuriall water to dissolue [Sol] and to make an Elixer thereof". ${ }^{71}$ Lord Willoughby transmitted the latter to Taylour. We also find Willoughby associated with one of Thomas Kelley's receipts. ${ }^{72}$ The fact that Kelley was

\footnotetext{
${ }^{66}$ The notes that Bayer claimed were about Isaac Holland refer rather to his son and fellow chymist John Isaac Holland. However, similarities between their viewpoints and writing styles make distinguishing their works extremely difficult. See fols. 24r, 44r and 56v in "The Margaret Manuscript." Raphael Patai, The Jewish Alchemists (Princeton: Princeton University Press, 1994), Chapter 22: "Isaac Hollandus and His Son John Isaac."

67 "The Margaret Manuscript," fol. 48v. On the Aureum vellus, see Raphael Patai, The Jewish Alchemists, 268. Vols. II and III of the first edition were printed in 1599.

68 "The Margaret Manuscript", fols. 43r and 114r. On Pontanus's Epistle, see Adam McLean, "Pontanus Epistle on the mineral fire," The Alchemy Web Site [http:/www.levity.com/alchemy/pontanus.html, accessed 28 July 2010].

69 "The Margaret Manuscript", fol. 5v. Dyer is also mentioned on fols. 6r, 19v and 25v.

${ }^{70}$ Ibid., fols. $19 \mathrm{v}, 20 \mathrm{r}$ and $21 \mathrm{r}$.

${ }^{71}$ Ibid., fols. $25 \mathrm{r}, 63 \mathrm{v}$ and $21 \mathrm{v}$.

72 Ibid., fol. 20r.
} 
cited as Sir Edward indicates that he sent these receipts after 1589, when Rudolf II knighted him; similarly, the references to Sir Edward Dyer, whom Elizabeth I knighted in 1596, date from between that year and approximately 1598, when "The Margaret Manuscript" was compiled. As Bayer has previously discussed, "Mr [Thomas] Webb" on folio 5v, "Mr [Leonard] Digges" on 44r and the "Duke of Brunswick" on 57r likely indicate additional links to the Dee-Kelley circle. ${ }^{73}$ In 1594 Dee had feared implication in a chymical coining scandal that nearly cost Webb his life; the queen's miniaturist Nicholas Hilliard intervened on behalf of Webb's accomplice, goldsmith Abel Fecknam. ${ }^{74}$ Kelley and his brother were connected with this chymical coterie for obvious reasons, but the involvement of Dyer and Willoughby warrants closer examination.

Given her status before marriage as one of the queen's maids of honor, Margaret Clifford would likely have been acquainted with Edward Dyer, and eager to converse about their shared interest. Dee formed an additional link between the two, his enduring friendship with Dyer dating from $1566 .{ }^{75}$ A close friend of Philip Sidney and client of Robert Dudley, earl of Leicester, he accompanied both on a visit to Dee's Mortlake home on 16 January $1577 .^{76}$ As discussed in Chapter 2, Dyer and Sidney studied chymistry under Dee's tutelage; together they invested in Frobisher's exploratory voyages in search of gold. ${ }^{77}$ The physician — and unapologetic Paracelsian — Thomas Moffet cleverly eulogized this relationship in Nobilis, his biography of Sidney: "Deo duce, Dio praeceptore, Diero socio", that is, God was Sidney's ultimate guide, Dee his teacher and Dyer his companion. ${ }^{78}$ Dyer's interest in chymistry persisted. In May of 1588, Elizabeth I sent him to Trebon in Bohemia to assess the validity of Edward Kelley's claim that he had

\footnotetext{
${ }^{73}$ Bayer, "Lady Margaret," 276-8. For additional links with "Mr Digges," see Backlund, "Footsteps," 300. Additionally, "Mr Eden" on fol. 51v of "The Margaret Manuscript" may refer to Richard Eden (1520-1576), who shared Dee's interests in chymistry, cosmography and New World exploration.

${ }_{75}^{74}$ See Parry, Arch-Conjuror, Ch. 20.

${ }^{75}$ Steven W. May, "Sir Edward Dyer (1543-1607)," ODNB, online edn. [http://www.oxforddnb.com/view/article/8346, accessed 8 August 2010].

${ }^{76}$ Dee, The Private Diary, p. 3.

${ }^{77}$ May, "Sir Edward Dyer," ODNB.

${ }^{78}$ Thomas Moffet, Nobilis or A View of the Life and Death of a Sidney, trans. V.B. Heltzel and H.H. Hudson (San Marino: Huntington Library, 1940): 13.
} 
transmuted base metals into gold. The following year, the countess of Shrewsbury consulted Dyer regarding the medicinal value of gold salts. ${ }^{79}$ This indicates her confidence in his chymical expertise. The queen respected his judgment in these matters as well. In 1590, she sent him back to Prague, hoping to persuade Kelley and his gold-making skills to return to England. Elizabeth may have doubted Kelley's claims, but she could not risk the possibility of Rudolf II or another foreign patron benefiting financially from English ingenuity. Though he was ultimately unsuccessful, Dyer did undertake extensive chymical experimentation with Kelley while in Bohemia. ${ }^{80}$ Fascination with chymistry connected Dyer to the Dee-Kelley circle.

Margaret Clifford's place at court also connected her with Lord Willoughby. "The Margaret Manuscript" provides additional evidence of his familiarity with iatrochemistry and chrysopoeia found in his extant letters to Lady Margaret. He may have copied Thomas Kelley's “excelent preparation of Siluer for paynes in the Heade, \& other Diseases" for Taylour, who noted that Willoughby called the resulting substance "the Vitrioll of Luna". 81 A "Mercuriall water" also came to Taylour by way of Willoughby, who obtained it while visiting Edward Kelley at his house near Prague. ${ }^{82}$ Like Edward Dyer, he traveled to Bohemia as the queen's trusted servant. In a letter to a Mr. Aldrich, John Dee's son Arthur recalled Willoughby's presence in Prague, where he supposedly witnessed a transmutation. ${ }^{83}$ His time there has otherwise not been well documented. However, Willoughby's presence in "The Margaret Manuscript" and interactions with Thomas Moffet signal a longstanding interest in specifically Paracelsian medicine. Given his obvious fascination with chymical matters, it was natural that he would develop and maintain an association with the Dee-Kelley circle.

\footnotetext{
${ }^{79}$ May, "Sir Edward Dyer," ODNB.

${ }^{80}$ Ibid.

81 "The Margaret Manuscript," fol. 20r.

82 Ibid., fol. $21 \mathrm{v}$.

${ }^{83}$ Bayer, "Lady Margaret," 277.
} 
In addition to illuminating the countess of Cumberland's chymical associates,

“The Margaret Manuscript" also tells us about her understanding of chymical principles.

Because Lady Margaret did not compile but rather inherited these recipes, we cannot make many suppositions about her chymical practice on the basis of its contents. However, its approach to chymistry, the divine and nature may illuminate Lady Margaret's own views.

In contrast to the writings of Margaret Hoby and Grace Mildmay, "The Margaret Manuscript" did not treat charitable medicine as the solitary goal of chymistry. It was equally concerned with the production of the philosopher's stone. Accordingly, a cure "for the fallinge Sicknes" appears alongside "the Oyle of Salte", and a dual-purpose receipt promises " $[\mathrm{t}] \mathrm{o}$ make the excellent Waters out of Saturne to Dissolue Perle for Medicyne: And to open the Bodies of Mettales". ${ }^{84}$ These purposes differed sharply enough for Taylour to distinguish between "phisick \& alchimye". ${ }^{85}$ Both main hands recorded periodic criticisms of "vulgar Alchimisticall recaytes or practises". Scribe A claimed with particular vitriol that the "foolishe Alchimystes" "knowe not what they haue done, and vnderstand not the operation of Nature in this behalf, and therefore learn they nothinge". ${ }^{86}$ He evidently believed that many of his chymical compatriots labored under delusions about the very nature of transmutation, while others practiced deliberate fraud, running "hither and thither disceavinge this Manne today and that Manne tomorrow". 87 Alchemy herself he viewed

as a Ladie beloved of many, whoe is Chaste, and hath many maides in her house, $\mathrm{w}^{\mathrm{ch}}$ haue allwayes their eyes on their Mistres, and offer themselves in her name, to the ende to kepe her pure and vndefyled, from the hannts of so manye importunate woers, to witt, Vanitie, fraude, disceipt, Sophistrie, Couetousenes, falshood, Rasheboldenes, Lyinge, foolishenes, Pouertie, Dispaire, Ronnynge awaye, Bannishement and Beggarie, $\mathrm{w}^{\text {ch }}$ are the handemaides of Alchimye, whoe to kepe their Mystres that shee be not violated doe prostitute and geve over themselves wholie to the pleasures of those that be in love with her[.. $]^{88}$

\footnotetext{
84 "The Margaret Manuscript," fols. 25r, 26r and 19r, respectively.

${ }^{85}$ Ibid., fol. 35 r. See also fol. $44 \mathrm{v}$.

${ }^{86}$ Ibid., fols. $80 \mathrm{v}$ and $79 \mathrm{v}$.

${ }^{87}$ Ibid., fols. $83 \mathrm{v}-84 \mathrm{r}$ ("they beat but the empte strawe") and $92 \mathrm{v}$.

${ }^{88}$ Ibid., fols. $93 \mathrm{v}-94 \mathrm{r}$.
} 
The overtly sexual nature of this metaphor is apt given chymistry's status as an act of creation. Taylour even compared one stage of his work to "an infant in his Mothers wombe", accelerating the natural but time-consuming generation of metals in the womb of the earth. ${ }^{89}$ Here the active wooers, typically male natural philosophers, play the masculine role to Alchimye's passive femininity — in this tale, she is sought after and observed, with no role of her own but to be acted upon, though her handmaids actively protect her. Scribe A's scorn seems to have been reserved for anyone engaged with these maids; he accorded the philosophers or inventors of the art a great deal more respect, as did Christopher Taylour, suggesting clear distinctions in the practice and perception of chymistry by those most familiar with the art. ${ }^{90}$

"The Margaret Manuscript" mentions medicine or physic on more than fifty pages, including treatments for "paynes in the Heade \& other Diseases" as well as "Palsyes, Agues, hedaches, Rewme", the aforementioned "fallinge sickenes and manye other greifes". 91 A number of these cures "for manes bodye" ministered to "everye disease", suggesting some relationship to the philosopher's stone. ${ }^{92}$ Unlike Margaret Hoby's diary, which recounts specific patients and treatments, this manuscript is necessarily more theoretical, making it difficult to assess the extent to which these cures reflect actual experience. However, Scribe A — and Taylour, too, insofar as he valued his predecessor's work - displayed familiarity with contemporary medicine. In the "Treatise on Cachelah", he drew an apposite household analogy between the kitchen fire and that in the "vegetable stone" of the title, "by $\mathrm{w}^{\text {ch }}$ we dresse our medecyne". ${ }^{93}$ Our decidedly Paracelsian author distinguished this work from that of the Galenists, who "boaste themselves to doe away this heatt with Poppie, Endife \& Nightshade and other Colde symples, $\mathrm{w}^{\text {ch }}$ they cannot doe,

\footnotetext{
${ }^{89}$ Ibid., fol. $124 \mathrm{r}$.

${ }^{90}$ See, for instance, the "argument to proue the Arte of Alkemie to be true" on fol. 135v and 94r-94v ("Those that boaste... are no Philosophers"). Taylour described the authors he cited as "ph[ilosoph]ers" on fol. 115r.

${ }^{91}$ Ibid., fols. 20r, 110v and 25r.

92 Ibid., 48v.

${ }^{93}$ Ibid., fol. $87 \mathrm{v}$. The treatise, written by Scribe A, can be found on fols. $77 \mathrm{r}$ to $95 \mathrm{v}$.
} 
vnleasse that the heatt doe naturally Ceasse of it self". 94 Though Grace Mildmay’s practice showed that Galenic and Paracelsian theories could be used in tandem, the author of this treatise clearly found fault in the very logic driving "ye Gallynistes", going so far as to imply that any successes they experienced were happy accidents, the working of Nature herself.

Like Paracelsus, the author of "The Margaret Manuscript" emphasized the value of experience over inherited theory. Thus Taylour assured his sons that "nothinge is better then to studye contynually the worckes of nature: for we can never err yf we followe Nature". ${ }^{95}$ Scribe A evidently felt the same way, criticizing chymical activities that he believed ran "contrary to Nature" ${ }^{96}$ Nature is vividly present in the manuscript, filled with mystery yet directing the proper performance of chymical endeavors; those who merely dallied with alchemy's handmaids did so in defiance of Nature — and its creator. ${ }^{97}$ Taylour respected the natural balance of opposites and the union thereof, exemplified by the mystical hermaphrodite. ${ }^{98}$ He also believed that the work would help his sons to "see a truth in the Arte, leadinge you to a further \& better worck yf you followe Nature arighte". ${ }^{99}$ Dame Nature, like Taylour himself, acted as a guide. He exhorted them to make use of "Reason Nature and Arte" in their chymical work; the first was internal, the second external and the third contained in Taylour's library — and, indeed, "The Margaret Manuscript" itself. ${ }^{100}$

References to the divine throughout the manuscript suggest that both Scribe A and Taylour, like many chymists, perceived no conflict between their religious beliefs and perusal of the Book of Nature. Taylour compared the transformative work of the chymist to that of other skilled artisans: "god doth not make for us of Corne bread, of grapes wyne,

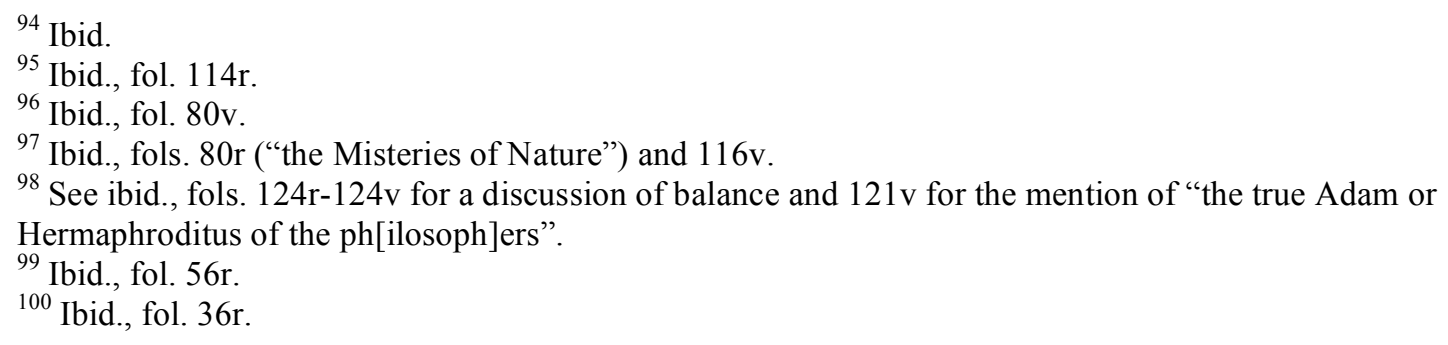


the Baker, and Vintenor ought to doe that". ${ }^{101}$ His defensive tone may indicate familiarity with counter-arguments calling the chymical art sacrilegious. The sense of responsibility in this remark is clear; not only do humans have the right to explore and experiment with the natural world, but their very creation in God's image obligated them to do so. Furthermore, any success in the laboratory could be directly attributed to God's hand, indicating He sanctioned the work. Scribe A concurred, claiming that "a Man cannot geve that $\mathrm{w}^{\text {ch }}$ he hath not received of God or of Nature". ${ }^{102}$ Like the baker and the vintner, the much-maligned chymist simply worked with raw materials provided by the Creator. Some received his blessing, learning "the Secreat of Secreates of god", but most were doomed to fail. ${ }^{103}$ According to Scribe A, only through the will of God were the fortunate few "Lovers of truth" delivered "from the deepe darkenes and the vnprofittable bablinge of suche as be Skylfull onlye by opinion". ${ }^{104}$

That darkness echoed in the world around him. He justified chymistry's exclusivity with millenarian convictions:

God also permitteth not, that purer thinges shoulde become Comon to the knowledge of everye Manne, especially in these dangerouse and evyll tymes, in $\mathrm{w}^{\mathrm{ch}}$ honestie and dishonestie, vertue and vice, truth and lyinge, are in one and the same estimation: we seeke not the truth but our owne glorye, wherefore God geveth vs an vnderstandinge perverted, that we hath one another, and beare malice one to another and are causes of the destruction of our Realme: the $\mathrm{w}^{\text {ch }}$ destruction is even at our doare. ${ }^{105}$

As earlier chapters have shown, the sense of doubt and trepidation pervading these lines was not unusual among chymists. The transmutational emphasis on renewal allowed them to combat the impending darkness and destruction of the End Times and actively help usher in heaven on earth. Lady Margaret, who supported her daughter through protracted legal battles to reclaim the inheritance that had been entailed away, likely appreciated the positive contribution she could make through chymistry at a time when these trials seemed

\footnotetext{
${ }^{101}$ Ibid., fol. $50 \mathrm{v}$.

${ }^{102}$ Ibid., fol. $83 \mathrm{v}$. See also fol. $88 \mathrm{r}$.

${ }^{103}$ Ibid., fol. $51 \mathrm{r}$.

${ }^{104}$ Ibid., fol. $94 \mathrm{v}$.

${ }^{105}$ Ibid., fols. $88 \mathrm{v}-89 \mathrm{r}$.
} 
insurmountable. Indeed, God ultimately rewarded the faith she and Anne exhibited.

Clifford commissioned Thomas Tymme, who shared her natural philosophical, occult and apocalyptic interests, to translate Dudley Fenner's Puritan tract Sacra Theologica in 1590. ${ }^{106}$ Eschatological concerns would continue to preoccupy chymists, whether practical or spiritual in emphasis. Seventeenth-century chymists like John Dury and his Hartlibian colleagues, as well as the Philadelphian Society led by John Pordage and Jane Lead(e), serve as evidence of the ongoing link between chymistry and millenarianism.

We can draw two conclusions about Margaret Clifford's chymical practice based on "The Margaret Manuscript". First, the combination of medical and more esoteric aims corroborates Lady Anne's words about her mother, as well as Willoughby's letters to the countess. Second, the representation of both God and his creation in the manuscript suggests a mindset that would have been familiar to Clifford, allowing for consistency in her beliefs and actions. The Book of Nature lay open before her and, like Margaret Hoby and Grace Mildmay, she used that knowledge to perform divinely sanctioned works.

A posthumous painting featuring the countess reveals the extent to which religion and chymistry informed her patronage and, indeed, her life. In 1646, three decades after her mother's death, Anne Clifford finally received her inheritance. In addition to her newly regained birthright, she now held the titles of Pembroke and Montgomery through her second marriage, to Mary Sidney Herbert's younger son Philip; the families continued to occupy the same social circles during the Stuart era. To commemorate her long-awaited victory Lady Anne commissioned a massive painted triptych documenting her life at three different stages: age fifty-six, age fifteen and, at the center, in utero, surrounded by her late

\footnotetext{
${ }^{106}$ Williamson, George, Third Earl, 292-3. See Thomas Tymme, The figure of Antichrist with the tokens of the end of the world (London, 1586); Thomas Tymme, A silver vvatch-bell (London, 1605); Joseph Du Chesne, The practise of chymicall, and hermeticall physicke, for the preseruation of health, trans. Thomas Tymme (London, 1605); Thomas Tymme, A dialogue philosophicall. Wherein natures secret closet is opened (London, 1612); and "A Light in Darkness" the prefatory essay to Tymme's ca. 1602 translation of John Dee’s Monas Hieroglyphica, MSS Ashmole 1440, 1459, 1819.
} 
parents and brothers. She framed her engagement with the world by means of literature, a characteristic inherited from her mother. ${ }^{107}$ The portrait of teenaged Anne in particular testifies to the importance of community in the acquisition and dissemination of knowledge. She stands before images of her governess, Anne Taylour, and her tutor, Samuel Daniel, who doubtless influenced the variety of books in the "Great Picture". Anne is depicted with, among other books, Agrippa's Vanity of Arts and Sciences, Philip Sidney's Arcadia and an epitome of Gerard's Herball that she may have copied in her youth. ${ }^{108}$ Daniel, the poet who had named Wilton House his "best Schoole", went on to one of the Clifford family homes in the late 1590s, around the same time that Christopher Taylour was compiling "The Margaret Manuscript” for his sons. ${ }^{109}$ Like Aemilia Lanyer and Edmund Spenser, another member of the Sidney circle, Daniel viewed Lady Margaret as a patron. ${ }^{110}$

Named in the dedications of at least eighteen spiritual and poetic works between 1578 and 1619, the countess of Cumberland rivaled Mary Sidney Herbert as the preeminent female patron of her generation. Others who sought her patronage included Peter Moffet, the Protestant younger brother of Thomas, professional writer Robert Greene, Puritan scholar Thomas Savile and a number of Church of England clergymen. ${ }^{11}$ Perhaps most curious is the dedication of physician Thomas Lodge's explicitly Catholic Prosopopoeia in 1596, wherein which he exhorted the virtuous countess to use the gifts

\footnotetext{
${ }^{107}$ Edith Snook, Women, Reading and the Cultural Politics of Early Modern England (Aldershot: Ashgate, 2005): 1-3.

${ }^{108}$ Cumbria Record Office, Kendal, WD/Hoth/MS JAC 332, Inscriptions on the Great Picture at Appleby Castle.

${ }^{109}$ John Pitcher, "Samuel Daniel (1562/3-1619)," ODNB, online edn.

[http://www.oxforddnb.com/view/article/7120, accessed on 10 May 2010].

${ }^{110}$ See Samuel Daniel, "A Letter from Octavia to Marcus Antonius" in The poeticall essayes of Sam. Danyel (London, 1599) and A panegyrike congratulatory to the kings maiestie. Also certaine epistles (London, 1603); Edmund Spenser, Foure hymnes, made by Edm. Spenser (London, 1596); and Susanne Woods, Lanyer: A Renaissance Woman Poet (Oxford: Oxford University Press, 1999); also Barbara K. Lewalski, "Re-Writing Patriarchy and Patronage: Margaret Clifford, Anne Clifford and Aemilia Lanyer," The Yearbook of English Studies, Vol. 21 (1991): 87-106, esp. p. 100.

${ }^{111}$ See Peter Moffet, The excellencie of the mysterie of Christ Iesus (London, 1590); Robert Greene, Penelopes Web (London, 1587); Thomas Savile, The raising of them that are fallen (London, 1606).
} 
proffered — the Virgin Mary's heavenly tears — "as the goldsmith his metall". ${ }^{112}$

This suggestive image recalls similarities between the work of smiths and chymists. A prolific writer who drew inspiration from Sidney's Arcadia, in 1591 Lodge had sailed under the command of Sir Thomas Cavendish, suggesting metallurgical interests, and in 1598 would receive a medical degree from the University of Avignon. ${ }^{113}$ He may not have known that celestial tears or dew signified the cleansing mercurial waters of chymistry, but Lady Margaret almost certainly did. ${ }^{114}$

In the central panel of the "Great Picture", Lady Anne specified that her mother be associated with four texts: the Bible, David's Psalms, the translated works of Seneca and a “written hand Booke of Alkumiste Exstraction of Distillation \& Excellent Medecines", said to have been compiled by the countess herself. ${ }^{115}$ Anne chose to remember and honor her mother's chymical knowledge alongside her piety, purity and strength. Indeed, it seems that, as with Margaret Hoby and Grace Mildmay, Lady Margaret's ability to heal through chymistry represented devotion in action. Though this book appears to have been lost, “The Margaret Manuscript" provides evidence of the countess's extensive associations and connects her to the wider Elizabethan chymical community.

Anne Clifford proudly remembered her mother as a passionate learner who made the most of the knowledge available to her. Lady Margaret cleverly operated within the confines of her social role. She patronized the translation of foreign works, invested in mining and exploratory ventures and cultivated friendships with members of the chymical community. ${ }^{116}$ The insight gained from these relationships allowed her to offer medical

\footnotetext{
112 Thomas Lodge, Prosopopoeia containing the teares of the holy, blessed, and sanctified Marie, the Mother of God (London, 1596).

${ }^{113}$ See Alexandra Halasz, "Thomas Lodge (1558-1625)," ODNB, online edn. [http://www.oxforddnb.com/view/article/16923, accessed 21 September 2010].

${ }_{114}$ Lyndy Abraham, A Dictionary of Alchemical Imagery (Cambridge: Cambridge University Press, 1998): 198. See also Archer, "Women and Alchemy," 15, 2.xii, 2.xiv.

${ }^{115}$ Cumbria Record Office, Kendal, WD/Hoth/MS JAC 332, Inscriptions on the Great Picture at Appleby Castle.

${ }^{116}$ Spence, "Margaret Clifford," ODNB.
} 
services appropriate for a woman of her standing. Margaret thus emulated the "Nurse of Nature" she introduced in her autobiographical letter. ${ }^{117}$ She nurtured and healed those around her by observing — and using to her advantage — the bounty readily available in God's creation.

In contrast to the other women who practiced chymistry during Elizabeth I's reign, Margaret Clifford did not take a strictly or even predominantly medical approach to the subject. Her family history and the variety of texts to which she was exposed from a relatively young age resulted in a necessarily broader viewpoint. Rather than seeking chymical information to augment her medical services as in the case of Margaret Hoby, Clifford approached the two areas of knowledge as complementary. Her medical expertise informed the chrysopoetic study she undertook, and her father-in-law's chymical texts enabled her to provide more comprehensive health care to the local community. Significantly, as has been the case with the other subjects of this study, Lady Margaret's Puritan beliefs informed her approach to chymistry. Isolated in a predominantly Catholic region, her good works contributed to the expansion of Protestantism; they also restored her own sense of home, and comfort, by transmuting the strange and unfamiliar into precisely the opposite.

${ }^{117}$ Williamson, George, Third Earl, 285. 


\section{Conclusion}

This thesis has examined female chymical activities during the reign of Queen Elizabeth I, suggesting that they represent a return to the art's Egyptian foundations, which were built upon both feminine and masculine principles. In the latter part of the sixteenth century, women's educations were relegated to the domestic sphere, chymistry was widespread and Queen Elizabeth, a real woman whose iconography claimed divine status for her, replaced the intangible goddess figures of the medieval era. These fundamental changes enabled gentlewomen to acquire and apply chymical knowledge.

Chapter 1 showed how the queen's interest in chymistry manifested in her iconography. Elizabeth's association with goddesses and symbols like the phoenix, pelican and serpent, I argued, perpetuated a rich history of secular rulers assuming mantles of sacred authority. While this deific imagery distanced the queen from her female subjects, it also constituted a bridge between the chymical world and English women, beginning with the gentry. Subsequent chapters examined Elizabeth's impact on individual gentlewomen.

In Chapter 2 I presented Grace Mildmay's iatrochemical papers in the context of her eschatological concerns, which have previously received little attention. Trained in medicine from a young age, Lady Grace maintained connections to the court in adulthood through her husband and in-laws. Thus her chymical practice had both motive (apocalypticism) and means (courtly affiliation). As her medical papers and meditations indicate, Grace's religious convictions and chymistry informed one another. Furthermore, she adopted aspects of both Galenism and Paracelsian theory in her practice. This reconciliatory stance emphasized the end product — good health — and testified to her engagement with a wider medical community implied in her papers.

Mary Sidney Herbert, the subject of Chapter 3, emulated the queen's chymistry in a more direct fashion: as muse and patron. The countess of Pembroke presided over her own 
microcosmic court at Wilton House, where she inspired creative works and installed her own chymical laboratory. While direct evidence of this laboratory has not survived, Lady Mary's familial connections and friends included members of the wider English chymical community. Her identification with her late brother Philip, from whose ashes she rose, phoenix-like, to complete and complement his literary and spiritual works, allowed her to transcend gender restrictions and enact the kind of transformation that figured so prominently in chymical texts familiar to them both.

Chapter 4 focused on Margaret Hoby and the spiritual diary she kept during the final years of Elizabeth's reign. A pious Puritan in predominantly Catholic North Yorkshire, Lady Margaret's religious convictions, like those of Grace Mildmay, led her to charitable healing and specifically chymical medicine. However, she attended to courtly matters more closely, counting among her friends and family associates of the queen and the English chymical community. I examined her motivations for practicing iatrochemistry in the context of these relationships, considering also how her childlessness may have impacted her interest in medicine.

Chapter 5 reinforced the importance of community in chymical practice by examining Margaret Clifford, a relative through marriage of both Herbert and Hoby. Esoteric letters from Lord Willoughby and her possession of a manuscript receipt book confirmed her daughter's claim that she "was a lover of the Study and practice of Alchimy". I suggested that her close connections to the magus John Dee's circle may reveal how she acquired "The Margaret Manuscript" now known to have been compiled by a chymist named Christopher Taylour, whose biography remains obscure. As a healer, hermetic student and patron, Lady Margaret embodied the variety of Elizabethan chymical practice.

The significance of symbols, allusions and allegories to chymical language makes it tempting to see in these women emblematic archetypes: queen, healing nurse, muse, 
industrious housewife, hermetic adept. However, just as chymical writers employed a variety of images to express their complex opus, so too each woman recalls numerous aspects of the feminine principle, as the queen's multilayered iconography indicates. The extent to which these characteristics overlap in my subjects reminds us that chymical activities in Elizabethan England took as many forms as there were practitioners. The preceding chapters merely provide a sampling based on available evidence. Nevertheless, one can draw several conclusions from my research.

First, community played a vital role for any Elizabethan practitioner irrespective of gender. I have already discussed the social links between Mary Sidney Herbert, Margaret Hoby and Margaret Clifford, whose chymical circles included both men and women, but Grace Mildmay's papers, too, sketch out the wider medical community with which she engaged. Mistress Hamblyn, the doctors whose cures she cited and the writers whose works she read influenced the nature of her practice and led her to incorporate chymical techniques and components. At a time when Paracelsian chymical theory was just beginning to reach a wider audience in England, knowing the right people could transform one's approach to medicine, whether licensed physician, gentlewoman or empiric.

Documents like Mildmay's papers and "The Margaret Manuscript" map out the chymical communities to which their authors belonged, telling us that, despite chymistry's reputation for secrets and sleight-of-hand, its practitioners willingly shared knowledge within a trusted social circle. This information did not remain the exclusive province of chymists, as literary, poetic and even religious references to celestial dew or the purifying process of trial by fire indicate. As chymically adept patrons, Mary Sidney Herbert and Margaret Clifford invited coded language from those who wished to be identified with their chymical communities. Chymistry's resonant symbolism thus became an effective tool for other modes of communication: we need look no further than poets John Donne 
and Henry Vaughan and playwrights William Shakespeare and Ben Jonson for evidence that " $[\mathrm{t}]$ he whole household of them are become alchemists". 1

Second, my research identifies religion as the singular motivating factor for acceptable female chymical practice. Indeed, the earliest chymists acknowledged the connection between faith and chymistry, the very ingredients of which derived from God's creation. Significantly, each of my subjects adhered to a more radical form of Protestantism than that espoused by their queen. They all engaged in charitable healing, as indicated by their extant writings, the testimonies of those who knew them, and the posthumous circulation of medical receipts bearing their names. As I have explicitly stated in the cases of Grace Mildmay and Margaret Hoby, through chymical medicine they transmuted good thoughts into good works in God's name.

Men shared this chymico-religious impulse. As we saw with Thomas Tymme and Paracelsus, concerns about the end of this life and the start of the next dictated appropriate behavior to the godly regardless of gender. However, my research suggests that women approached chymistry in a manner quite different from male natural philosophers. Whereas men exploited, perfected or surpassed the work of Dame Nature, unraveling and appropriating her secrets out of greed, curiosity or ambition, women, who had long been identified with the natural world, perceived in Dame Nature an extension of their own (natural) powers. ${ }^{2}$ Through her - through God's creation - they could better enact their innate ability to nurture and heal. Like their less controversial herbal counterparts, metals and minerals proliferated in the natural world for mankind's benefit.

Third, my thesis suggests that we need to reassess the role and nature of chymistry during Queen Elizabeth's reign, paying greater attention to the practical goals and benefits we overlook by amplifying the Great Work's esoteric qualities; its philosophical relationship to post-Reformation spiritual beliefs; and the communal basis for knowledge-

\footnotetext{
${ }^{1}$ Ben Jonson, The Works of Ben Jonson (London: Edward Moxon, 1838): 595.

${ }^{2}$ On the traditional approach, which I have here ascribed to men, see William Newman, Promethean Ambitions: Alchemy and the Quest to Perfect Nature (Chicago: University of Chicago Press, 2004): 4.
} 
transmission, which indicates opportunities for further research. By rejecting the assumption that chymistry's occult connections necessarily marginalized its practice, we gain a more accurate understanding of life during the latter part of the sixteenth century one unclouded by modern suppositions. The court's changing stance toward transmutation over the course of the Virgin Queen's reign deserves additional scrutiny, as does the profusion of chymical symbolism in Elizabeth's iconography. The preceding chapters also highlight an affinity between chymical (and particularly Paracelsian) theory and Protestantism, overlooking Catholicism's kinship where the deployment of symbolism is concerned.

Continued examination of Elizabethan women's receipt books for shared content and social connections will shed light on the spread of chymistry among the literate, the changing nature of household medical knowledge and the extent to which such texts shaped and reflected each writer's experiences. These healers mediated between chrysopoets, physicians and practitioners of nascent chemistry, occupying an oftoverlooked place in the history of science. Rebecca Laroche's recent study of female herbal ownership provides a useful methodology for such research, restoring a sense of identity to the acquisition and preservation of medical knowledge. ${ }^{3}$ While Deborah Harkness has emphasized similar values among London's natural philosophers, an assessment of the extent to which rural women healers formed a community would be a welcome addition to chymical historiography. ${ }^{4}$ Furthermore, gaining a fuller picture of women's relationship with chymistry during Elizabeth's reign will complement and provide background for excellent scholarship on seventeenth-century women's recipe books by, for instance, Jayne Archer, Elaine Leong and Edith Snook. ${ }^{5}$

\footnotetext{
${ }^{3}$ Rebecca Laroche, Medical Authority and Englishwomen's Herbal Texts, 1550-1650 (Aldershot: Ashgate, 2009).

${ }^{4}$ Deborah E. Harkness, The Jewel House: Elizabethan London and the Scientific Revolution (New Haven: Yale University Press, 2007).

5 Jayne Archer, "Women and chymistry in early modern England: the manuscript receipt book (c. 1616) of Sarah Wigges" in Gender and Scientific Discourse in Early Modern Culture, ed. Kathleen P. Long
} 
Those receipt manuscripts, as well as the proliferation of chymical publications during the Stuart era, contain the legacies of Elizabethan women chymical practitioners. The works of early modern English men like Thomas Norton, George Ripley, John Dee, Edward Kelley and Elias Ashmole eclipse the contributions of their female counterparts, leading to the mistaken impression that women's role in the royal art was marginal, if their presence was felt at all. That we find an increase in female chymists in the seventeenth century testifies to the impact of Elizabeth and her pioneering subjects, who came to chymistry obliquely, through religious convictions. In 1650 the pseudonymous Eugenius Philalethes, believed to be the clergyman Thomas Vaughan, wrote that chymistry is no way troublesome; a lady may read the Arcadia and at the same time attend this philosophy without disturbing her fancy. For my part, I think women are fitter for it than men, for in such things they are more neat and patient, being used to a small chemistry of sack-possets and other finical sugar-sops. ${ }^{6}$

Vaughan's language skips over the challenges and suffering earnest seekers of the philosopher's stone invariably faced, but crucially reminds us of chymistry's long association with women's work. He and his wife Rebecca performed distillations and experiments as partners, effectively bringing to fruition Maria the Jewess's adage on the chymical wedding: "Join the male and the female, and you will find that which is sought".

\footnotetext{
(Aldershot: Ashgate, forthcoming 2010); Elaine Leong, "Making Medicines in the Early Modern Household" in Bulletin of the History of Medicine, Vol. 82, No. 1 (2008): 145-68; Edith Snook, "“The Beautifying Part of Physic': Women's Cosmetic Practices in Early Modern England" in Journal of Women's History, Vol. 20, No. 3 (2008): 10-33.

${ }^{6}$ Eugenius Philalethes (Thomas Vaughan), Magia adamica or the antiquitie of magic... Whereunto is added a perfect, and full discoverie of the true coelum terrae (London, 1650): 118.
} 


\section{Bibliography}

\section{Primary Sources}

\section{Calendars and Catalogues}

Ellis, H. and F. Douce, eds. A Catalogue of the Lansdowne Manuscripts in the British Museum: With Indexes of Persons, Places and Matters. London: 1819.

Green, M.A.E., ed. Calendar of State Papers, Domestic Series, of the Reign of Elizabeth, 1591-1594. London: Longman, Green, Reader and Dyer, 1867.

. Calendar of State Papers, Domestic Series, of the Reign of Elizabeth, 1595-1597.

London: Longman, Green, Reader and Dyer, 1867.

. Calendar of State Papers, Domestic Series, of the Reign of Elizabeth, 1598-1601.

London: Longmans, Green, and Co., 1867.

Lemon, R., ed. Calendar of State Papers, Domestic Series, of the Reigns of Edward VI, Mary, Elizabeth, 1547-1580. London: Longman, Brown, Green, Longmans, \& Roberts, 1856.

Roberts, R.A., ed. Calendar of the Manuscripts of the Most Hon. the Marquis of Salisbury, Preserved at Hatfield House, Hertfordshire, Vol. 5: 1591-1595. London: Her Majesty's Stationery Office, 1894.

. Calendar of the Manuscripts of the Most Hon. the Marquis of Salisbury,

Preserved at Hatfield House, Hertfordshire, Vol. 6: 1596. London: Her Majesty's Stationery Office, 1895.

Scargill-Bird, S.R., ed. Calendar of the Manuscripts of the Most Hon. the Marquis of Salisbury, Preserved at Hatfield House, Hertfordshire, Vol. 1: 1306-1571. London: Her Majesty's Stationery Office, 1883.

\section{Manuscript Collections}

British Library, Harley Manuscripts.

$\longrightarrow$, Lansdowne Collection.

$\longrightarrow$, Sloane Manuscripts.

Hatfield House, Cecil Papers.

The National Archives of the United Kingdom, SP 12: Secretaries of State: State Papers Domestic, Elizabeth I. 


\section{Manuscripts}

British Library, MS Egerton 2614.

Cumbria Record Office, Kendal, WD/Hoth/Box 44.

$\longrightarrow, \mathrm{WD} /$ Hoth/A988/5.

$\longrightarrow$, WD/Hoth/MS JAC 332.

Trinity College, Cambridge, Wren Library, MS O.1.51.

\section{Printed Works}

Agnello, Giovanni Baptista. A reuelation of the secret spirit of Alchymie, trans. Richard Napier. London: 1623.

Anon. A good huswifes handmaide for the kitchin. London: 1594.

Anon. Cabala, Sive Scrinia Sacra: Mysteries of State and Government in Letters, London: 1691.

Aubrey, John. Brief Lives, ed. Oliver Lawson Dick. Boston: David R. Godine, 1999.

Aylmer, John. An harborovve for faithful and trevve subiectes agaynst the late blowne blast. Strasbourg/London: 1559.

Baker, George, trans. The newe Jewell of Health. London: 1576.

Bancroft, Richard. A sermon preached at Paules Crosse the 9. of Februarie. London: 1588 .

Banister, Richard. A Treatise of One Hvndred and Thirteene Diseases of the Eyes, and Eye-Liddes. London: 1622.

Becon, Thomas. The worckes. London: 1564.

Bostocke, Richard. The difference between the auncient phisicke... and the latter phisicke. London: 1585.

Case, John. Sphaera civitatis. Oxford: 1588.

Cleaver, Robert. A godlie forme of householde gouernment. London: 1598.

Clifford, Anne. The Memoir of 1603 and The Diary of 1616-1619, ed. Katherine O. Acheson. Peterbrough: Broadview Press, 2006.

Dawson, Thomas. The good husvvifes ievvell. London: 1587.

Da Vigo, Giovanni. The most excelent worckes of chirurgery, ed. Bartholomew Traheron. London: 1550.

Daniel, Samuel. Selected Poetry and a Defense of Rhyme, ed. Geoffrey G. Hiller. Asheville: Pegasus Press, 1998. 
- The poeticall essayes of Sam. Danyel. London: 1599.

- A panegyrike congratulatory to the kings maiestie. Also certaine epistles. London: 1603.

Dee, John. A True \& Faithful Relation of What Passed for Many Yeers Between Dr. John Dee and Some Spirits, ed. Meric Casaubon. London: 1659.

- General and rare memorials pertayning to the perfect arte of nauigation. London: 1577.

—. Compendious Rehearsal. London: 1597.

—. A letter, containing a most briefe discourse apologeticall. London: 1599.

—. The Private Diary of Dr. John Dee, ed. James Orchard Halliwell. London: 1842.

Du Chesne, Joseph. The practise of chymicall, and hermeticall physicke, for the preseruation of health, trans. Thomas Tymme. London: 1605.

Forman, Simon. The autobiography and personal diary of Dr. Simon Forman, ed. James Orchard Halliwell. London: 1849.

French, John. The Art of Distillation. London: 1651.

Gerard, John. The Herball or Generall Historie of Plantes. London: 1597.

Gilbert, Sir Humphrey. Queene Elizabethes achademy, ed. F.J. Furnivall. London: 1869.

Greene, Robert. Penelopes Web. London: 1587.

Gosynhyll, Edward. Here begynneth a lytle boke named the Schole house of women. London: 1541.

Herbert, Mary Sidney. Collected Works of Mary Sidney Herbert, Countess of Pembroke, 2 Vols., eds. Margaret P. Hannay, Noel J. Kinnamon and Michael G. Brennan. Oxford: Clarendon Press, 1998.

- The triumph of death, and other unpublished and uncollected poems, ed. G.F. Waller. Salzburg: University of Salzburg, 1977.

Herbert, William. Poems written by the Right Honorable William earl of Pembroke, lord steward of his Majesties houshold. London: 1660.

Hoby, Margaret. Diary of Lady Margaret Hoby. London: Routledge, 1930.

- The Private Life of an Elizabethan Lady: The Diary of Lady Margaret Hoby, 1599-1605. Thrupp: Sutton, 1998.

James VI of Scotland, Daemonologie, in forme of a Dialogue. Edinburgh: 1597.

Jonson, Ben. The Works of Ben Jonson. London: 1838.

Jorden, Edward. A brief discourse of a disease called the suffocation of the mother. London: 1603. 
Knox, John. The first blast of the trumpet against the monstrous regiment of women. Geneva: 1558.

Lodge, Thomas. Prosopopoeia containing the teares of the holy, blessed, and sanctified Marie, the Mother of God. London: 1596.

Lyly, John. Euphues and his England. London: 1581.

Markham, Gervase. The English House-vvife. London: 1631.

Meres, Francis. Palladis tamia. London: 1598.

Moffet, Peter. The excellencie of the mysterie of Christ Iesus. London: 1590.

Moffet, Thomas. Nobilis or A View of the Life and Death of a Sidney and Lessus

Lugubris, eds. Virgil B. Heltzel and Hoyt H. Hudson. San Marino: The Huntington Library, 1940.

. The silkewormes and their flies: liuely described in verse, by T.M. a countrie farmar, and an apprentice in physicke. London: 1599.

Naunton, Sir Robert. Fragmenta regalia, or, Observations on the late Queen Elizabeth, her times and favorites. London: 1641.

Partridge, John. The treasurie of commodious conceits, \& hidden secrets and may be called, the huswiues closet, of healthfull prouision. London: 1573.

Philalethes, Eugenius. Magia adamica or the antiquitie of magic... Whereunto is added a perfect, and full discoverie of the true coelum terrae. London: 1650.

Plat, Sir Hugh. Delightes for ladies, to adorne their persons, tables, closets, and distillatories. London: 1600.

Plowden, Edmund. The Commentaries, or Reports, Part I. London: 1816.

Ripley, George. The compound of alchymy, ed. Ralph Rabbards. London: 1591.

Ruscelli, Girolamo. The secretes of the reuerend Maister Alexis of Piemont. London: 1558.

Sandford, James, trans. Houres of recreation, or afterdinners. London: 1576.

Savile, Thomas. The raising of them that are fallen. London: 1606.

Scot, Reginald. The disouerie of witchcraft. London: 1584.

Sidney, Sir Philip. The Countesse of Pembrokes Arcadia. London: 1593.

- and Mary Sidney Herbert. The Sidney Psalter: The Psalms of Sir Philip and Mary Sidney. Oxford: Oxford University Press, 2009.

Spenser, Edmund. Foure hymnes, made by Edm. Spenser. London: 1596. . The Faerie Qveene, eds. A.C. Hamilton, Hiroshi Yamashita and Toshiyuki Suzuki. London: Longman, 2006. 
Trithemius, Johannes. Annales Hirsaugienses, Vol. 2. Leiden: 1690.

Turner, William. A new herbal. London: 1551.

- The first and seconde partes of the herbal of William Turner Doctor in Phisick, lately ouersene, corrected and enlarged with the thirde parte...Here vnto is ioyned also a booke of the bath of Baeth in England. Cologne: 1568.

Tusser, Thomas. A hundreth good pointes of husbandrie. London: 1557.

Tymme, Thomas. The figure of Antichrist with the tokens of the end of the world. London: 1586.

—. A silver vvatch-bell. London: 1605.

- A dialogue philosophical. Wherein natures secret closet is opened. London: 1612.

W.M. The Queens closet opened. London: 1655.

Watson, Thomas. Amintae gaudia Thoma VVatsono Loninensi, iuris studioso. London: 1592.

\section{Online Databases}

Adam Matthew Digital, Defining Gender, 1450-1910,

[http://www.gender.amdigital.co.uk].

$\longrightarrow$, Perdita Manuscripts I: Women Writers, 1500-1700,

[http://www.perditamanuscripts.amdigital.co.uk].

Chadwyck-Healey, Early English Books Online (EEBO),

[http://eebo.chadwyck.com].

Gale Cengage Learning, State Papers Online: The Government of Britain, 1509-1714,

[http://www.gale.cengage.co.uk/statepapers].

Pelling, Margaret and Francis White, eds., Physicians and Irregular Medical Practitioners in London 1550-1640: Database (2004),

[http://www.british-history.ac.uk/report.aspx?compid=17251].

Royal College of Physicians, Munk's Roll,

[http://munksroll.rcplondon.ac.uk].

TannerRitchie Publishing, Medieval and Early Modern Sources Online,

[http://sources.tannerritchie.com]. 


\section{Secondary Sources}

\section{Articles}

Alexander, Paul J. "The Medieval Legend of the Last Roman Emperor and its Messianic Origin." Journal of the Warburg and Courtauld Institutes, Vol. 41 (1978): 1-15.

Archer, Jayne. “The Queens' Arcanum: Authority and Authorship in The Queens Closet Opened. The Renaissance Journal, Vol. 1, No. 6 (2002).

Bayer, Penny. "Lady Margaret Clifford's Alchemical Receipt Book and the John Dee Circle." Ambix, Vol. 52, No. 3 (2005): 271-84.

Crawford, Julie. “Reconsidering Early Modern Women's Reading, or, How Margaret Hoby Read Her de Mornay." The Huntington Library Quarterly, Vol. 73, No. 2 (2010): 193-223.

Crossley, D.W. "The Management of a Sixteenth-Century Ironworks." The Economic History Review, Vol. 19, No. 2 (1966): 273-88.

DeVun, Leah. "The Jesus Hermaphrodite: Science and Sex Difference in Premodern Europe." Journal of the History of Ideas, Vol. 69, No. 2 (2008): 193-218.

Eamon, William. “Arcana Disclosed: The Advent of Printing, the Books of Secrets Tradition and the Development of Experimental Science in the Sixteenth Century." History of Science, Vol. 22 (1984): 111-50.

Evenden, Doreen A. "Gender Differences in the Licensing and Practicing of Female and Male Surgeons in Early Modern England.” Medical History, Vol. 42, No. 2 (1998): 194-216.

Fissell, Mary E. "Introduction: Women, Health, and Healing in Early Modern Europe." Bulletin of the History of Medicine, Vol. 82 (2008): 1-17.

Forster, Jennifer. "Anticipating the Apocalypse: An Elizabethan Prophecy." The Historian, Vol. 63, No. 3 (2001): 601-17.

Green, Monica H. “From 'Diseases of Women' to 'Secrets of Women': The Transformation of Gynecological Literature in the Later Middle Ages." Journal of Medieval and Early Modern Studies, Vol. 30, No. 1 (2000): 5-39.

Gwyn, David. "Richard Eden, Cosmographer and Alchemist." The Sixteenth Century Journal, Vol. 15, No. 1 (1984): 13-34.

Harkness, Deborah E. "A View from the Streets: Women and Medical Work in Elizabethan London." Bulletin of the History of Medicine, Vol. 82, No. 1 (2008): $52-85$.

. "Managing an Experimental Household: The Dees of Mortlake." Isis, Vol. 88, No. 2 (1997): 247-62. 
Hellwarth, J.W. “'Be unto me as a precious ointment': Lady Grace Mildmay, sixteenth-century female practitioner." Dynamis, Vol. 19 (1999): 95-117.

Houliston, V.H. "Sleepers Awake: Thomas Moffet's Challenge to the College of Physicians of London, 1584." Medical History, Vol. 33 (1989): 235-46.

Janacek, Bruce. "Thomas Tymme and Natural Philosophy: Prophecy, Alchemical Theology, and the Book of Nature." The Sixteenth Century Journal, Vol. 30, No. 4 (1999): 987-1007.

Josten, C.H. “A Translation of John Dee's 'Monas Hieroglyphica' (Antwerp, 1564), with an Introduction and Annotations." Ambix, Vol. 12, Nos. 2/3 (1964): 84-221.

. "Truth's Golden Harrow: An Unpublished Alchemical Treatise by Robert Fludd." Ambix, Vol. 3, Nos. 3/4 (1949): 91-150.

Kocher, Paul H. "The Old Cosmos: A Study in Elizabethan Science and Religion." The Huntington Library Quarterly, Vol. 15, No. 2 (1952): 101-21.

Lamb, Mary Ellen. “The Countess of Pembroke's Patronage.” English Literary Renaissance, Vol. 12, No. 2 (1982): 162-79.

Leong, Elaine. "Making Medicines in the Early Modern Household." Bulletin of the History of Medicine, Vol. 82, No. 1 (2008): 145-68.

Lewalski, Barbara K. "Re-Writing Patriarchy and Patronage: Margaret Clifford, Anne Clifford and Aemilia Lanyer." The Yearbook of English Studies, Vol. 21 (1991): 87-106.

Linden, Stanton J. "Mrs Mary Trye, Medicatrix: Chemistry and Controversy in Restoration England." Women's Writing, Vol. 1, No. 3 (1994): 341-53.

Montrose, Louis A. "Idols of the Queen: Policy, Gender, and the Picturing of Elizabeth I." Representations, No. 68 (1999): 108-61.

Newman, William R. and Lawrence M. Principe. "Alchemy and Chemistry: The Etymological Origins of a Historiographic Mistake." Early Science and Medicine, Vol. 3, No. 1 (1998): 32-65.

Obrist, Barbara. "Visualization in Medieval Alchemy." HYLE: International Journal for Philosophy of Chemistry, Vol. 9, No. 2 (2003): 131-70.

Pagel, Walter and Pyarali Rattansi. "Vesalius and Paracelsus." Medical History, Vol. 8, No. 4 (1964): 309-28.

Parry, Glyn. "John Dee and the Elizabethan British Empire in its European Context." The Historical Journal, Vol. 49, No. 3 (2006): 643-75.

Pritchard, Allan. "Thomas Charnock's Book Dedicated to Queen Elizabeth." Ambix, Vol. 26, No. 1 (1979): 56-73.

Roberts, Sasha. "Women's Literary Capital in Early Modern England: Formal Composition and Rhetorical Display in Manuscript and Print." Women's Writing, Vol. 14, No. 2 (2007): 246-69. 
Snook, Edith. “"The Beautifying Part of Physic': Women's Cosmetic Practices in Early Modern England." Journal of Women's History, Vol. 20, No. 3 (2008): 1033.

Spence, Richard T. "Mining and Smelting in Yorkshire by the Cliffords, Earls of Cumberland, in the Tudor and Early Stuart Period." Yorkshire Archaeological Journal, Vol. 64 (1992): 157-83.

Stolberg, Michael. "A Woman Down to Her Bones: The Anatomy of Sexual Difference in the Sixteenth and Early Seventeenth Centuries." Isis, Vol. 94, No. 2 (2003): 27499.

Waller, G.F. “"This Matching of Contraries': Bruno, Calvin and the Sidney Circle." Neophilologus, Vol. 56, No. 3 (1972): 331-43.

Walsham, Alexandra. "“Frantick Hacket': Prophecy, Sorcery, Insanity, and the Elizabethan Puritan Movement." The Historical Journal, Vol. 41, No. 1 (1998): 27-66.

Warren, Nancy Bradley. "Tudor Religious Cultures in Practice: The Piety and Politics of Grace Mildmay and Her Circle." Literature Compass, Vol. 3, No. 5 (2006): 1011 43.

\section{Books}

Abraham, Lyndy. A Dictionary of Alchemical Imagery. Cambridge: Cambridge University Press, 1998.

Adams, Alison and Stanton J. Linden, eds. Emblems and Alchemy. Glasgow: Glasgow Emblem Studies, 1998.

Åkerman, Susanna. Queen Christina of Sweden and Her Circle: The Transformation of a Seventeenth-Century Philosophical Libertine. Leiden: Brill, 1991.

Archer, Jayne Elisabeth, Elizabeth Goldring and Sarah Knight, eds. The Progresses, Pageants, and Entertainments of Queen Elizabeth I. Oxford: Oxford University Press, 2007.

Armstrong, Nancy and Leonard Hennenhouse, eds. The Ideology of Conduct: Essays on Literature and the History of Sexuality. London: Methuen \& Co., 1987.

Auerbach, Erna. Nicholas Hilliard. London: Routledge and Kegan Paul, 1961.

Aughterson, Kate. Renaissance Woman: A Sourcebook: Constructions of Femininity in England. London: Routledge, 1995.

Axton, Marie. The Queen's Two Bodies. London: Royal Historical Society, 1977.

Ball, Philip. The Devil's Doctor: Paracelsus and the World of Renaissance Magic and Science. New York: Farrar, Straus and Giroux, 2006.

Beier, Lucinda. Sufferers \& Healers: The Experience of Illness in Seventeenth-Century England. London: Routledge \& Kegan Paul, 1987. 
Beilin, Elaine V. Redeeming Eve: Women Writers of the English Renaissance. Princeton: Princeton University Press, 1990.

Berry, Philippa. Of Chastity and Power: Elizabethan Literature and the Unmarried Queen. London: Routledge, 1989.

Bindoff, Stanley T. The House of Commons: 1509-1558; Members D-M. London: Secker \& Warburg Ltd., 1982).

Breuer, Heidi. Crafting the Witch: Gendering Magic in Medieval and Early Modern England. New York: Routledge, 2009.

Clark, Mary T., ed. An Aquinas Reader. Bronx: Fordham University Press, 2000.

Clark, Peter, ed. The Cambridge Urban History of Britain, Volume II: 1540-1840. Cambridge: Cambridge University Press, 2000.

Clucas, Stephen, ed. John Dee: Interdisciplinary Studies in English Renaissance Thought. Dordrecht: Springer, 2006.

Cobb, Cathy and Harold Goldwhite. Creations of Fire: Chemistry's Lively History from Alchemy to the Atomic Age. New York: Plenum Press, 195.

Connolly, Annaliese and Lisa Hopkins, eds. Goddesses and Queens: The Iconography of Elizabeth I. Manchester: Manchester University Press, 2007.

Cressy, David. Birth, Marriage, and Death: Ritual, Religion, and the Life-Cycle in Tudor and Stuart England. Oxford: Oxford University Press, 1999.

Cross, Claire. The Puritan Earl: The Life of Henry Hastings, 3rd Earl of Huntingdon, 1556-1596. London: Macmillan, 1966.

Debus, Allen G. Chemistry, Alchemy and the New Philosophy, 1550-1700. London: Variorum Reprints, 1987.

- The Chemical Philosophy: Paracelsian Science and Medicine in the Sixteenth Century. Mineola: Dover, 2002.

DeVun, Leah. Prophecy, Alchemy, and the End of Time: John of Rupescissa in the Late Middle Ages. New York: Columbia University Press, 2009.

Dickson, Donald. Thomas and Rebecca Vaughan's Aqua Vitæ: Non Vitis. Tempe: Arizona Center for Medieval and Renaissance Studies, 2001.

Doran, Susan. Monarchy and Matrimony: The Courtships of Elizabeth I. London: Routledge, 1996.

and Thomas Freeman, eds. The Myth of Elizabeth. Houndmills: Palgrave Macmillan, 2003.

Dowd, Michelle M. and Julie A. Eckerle, eds. Genre and Women's Life Writing in Early Modern England. Aldershot: Ashgate, 2007.

Eales, Jacqueline. Women in Early Modern England, 1500-1700. London: UCL Press, 1998. 
Eamon, William C. Books of Secrets and the Empirical Foundations of English Natural Philosophy 1550-1660. Ann Arbor: University Microfilms International, 1986.

- Science and the Secrets of Nature: Books of Secrets in Medieval and Early Modern Culture. Princeton: Princeton University Press, 1994.

Fell Smith, Charlotte. John Dee 1527 to 1608. London: Constable \& Company, 1909.

Fletcher, Anthony. Gender, Sex and Subordination in England 1500-1800. New Haven: Yale University Press, 1995.

— and John Stevenson, eds. Order and Disorder in Early Modern England. Cambridge: Cambridge University Press, 1985.

French, Peter J. John Dee: The World of an Elizabethan Magus. London: Routledge and Kegan Paul, 1972.

Frye, Susan. Elizabeth I: The Competition for Representation. New York: Oxford University Press, 1993.

Garrett, Martin. Sidney: The Critical Heritage. London: Routledge, 2003.

Gilson, J.P. Lives of Lady Anne Clifford Countess of Dorset, Pembroke and Montgomery (1590-1676) and of Her Parents Summarized by Herself. London: The Roxburghe Club, 1916.

Govinda, Lama Anagarika. Foundations of Tibetan Mysticism. New York: Samuel Weiser, 1969.

Hackett, Helen. Virgin Mother, Maiden Queen: Elizabeth I and the Cult of the Virgin Mary. Houndmills: Macmillan, 1995.

Haigh, Christopher, ed. The English Reformation Revised. Cambridge: Cambridge University Press, 1987.

Hannay, Margaret P. Philip's Phoenix: Mary Sidney, Countess of Pembroke. Oxford: Oxford University Press, 1990.

Harrison, Peter. The Bible, Protestantism and the Rise of Natural Science. Cambridge: Cambridge University Press, 1998.

Harkness, Deborah. The Jewel House: Elizabethan London and the Scientific Revolution. New Haven: Yale University Press, 2007.

Hart, Vaughan. Art and Magic in the Court of the Stuarts. London: Routledge, 1994.

Heal, Felicity and Clive Holmes. The Gentry in England and Wales, 1500-1700. Stanford: Stanford University Press, 1994.

Huffman, William H. Robert Fludd and the End of the Renaissance. London: Routledge, 1988.

Hull, Suzanne. Chaste, Silent \& Obedient: English Books for Women, 1475-1640. San Marino: Huntington Library, 1982. 
Hunter, Lynette and Sarah Hutton, eds. Women, Science and Medicine, 1500-1700: Mothers and Sisters of the Royal Society. Thrupp: Sutton Publishing, 1997.

Jacob, Margaret C. Stangers Nowhere in the World: The Rise of Cosmopolitanism in Early Modern Europe. Philadelphia: University of Pennsylvania Press, 2006.

Jones, Norman. The Birth of the Elizabethan Age: England in the 1560s. Oxford: Blackwell, 1995.

- The English Reformation: Religion and Cultural Adaptation. Oxford: Blackwell, 2002.

Kantorowicz, Ernst H. The King's Two Bodies: A Study in Mediaeval Political Theology. Princeton: Princeton University Press, 1957.

Kassell, Lauren. Medicine and Magic in Elizabethan London: Simon Forman: Astrologer, Alchemist and Physician. Oxford: Clarendon, 2005.

Kass-Simon, G. and Patricia Farnes, eds. Women of Science: Righting the Record. Bloomington: Indiana University Press, 1993.

Koertge, Noretta, ed. A House Built on Sand: Exposing Postmodernist Myths About Science. Oxford: Oxford University Press, 1998.

Ladurie, Emmanuel le Roy. The Beggar and the Professor A Sixteenth-Century Family Saga, trans. Arthur Goldhammer. Chicago: University of Chicago press, 1997.

Laroche, Rebecca. Medical Authority and Englishwomen's Herbal Texts, 1550-1650. Aldershot: Ashgate, 2009.

Lembert, Alexandra and Elmar Schenkel, eds. The Golden Egg: Alchemy in Art and Literature. Berlin: Galda und Wilch, 2002.

Levin, Carole, Jo Eldridge Carney and Debra Barrett-Graves, eds. Elizabeth I: Always Her Own Free Woman. Aldershot: Ashgate, 2003.

Lewalski, Barbara Kiefer. Writing Women in Jacobean England. Cambridge: Harvard University Press, 1993.

Linden, Stanton J. Darke Hierogliphicks: Alchemy in English Literature from Chaucer to the Restoration. Lexington: University Press of Kentucky, 1996.

, ed. Mystical Metal of Gold: Essays on Alchemy and Renaissance Culture. New York: AMS Press, Inc., 2007.

Long, Kathleen P. Hermaphrodites in Renaissance Europe. Aldershot: Ashgate, 2006. ed. Gender and Scientific Discourse in Early Modern Culture. Aldershot: Ashgate, 2010.

Malcolmson, Cristina and Mihoko Suzuki, eds. Debating Gender in Early Modern England, 1500-1700. Houndmills: Palgrave Macmillan, 2002.

Maxwell-Stuart, P.G. The Chemical Choir: A History of Alchemy. London: Hambledon Continuum, 2008. 
McLaren, A.N. Political Culture in the Reign of Elizabeth I: Queen and Commonwealth, 1558-1585. Cambridge: Cambridge University Press, 1999.

Mendelsohn, Everett and Helga Noworthy, eds. Nineteen Eighty-Four: Science Between Utopia and Dystopia. New York: D. Riedel Publishing, 1984.

Merchant, Carolyn. The Death of Nature: Women, Ecology, and the Scientific Revolution. San Francisco: Harper \& Row, 1980.

Neale, J.E. Elizabeth I and Her Parliaments: 1584: 1601. London: St. Martin's Press, 1958.

Newman, Barbara. God and the Goddesses: Vision, Poetry, and Belief in the Middle Ages. Philadelphia: University of Pennsylvania Press, 2005.

Newman, William. Promethean Ambitions: Alchemy and the Quest to Perfect Nature. Chicago: University of Chicago Press, 2004.

- Gehennical Fire: The Lives of George Starkey, An American Alchemist in the Scientific Revolution. Cambridge: Harvard University Press, 1994.

Nicholls, Charles. The Chemical Theatre. London: Routledge \& Kegan Paul, 1980.

Nichols, John. Progresses, Public Processions, \&c. of Queen Elizabeth, 3 Vols. London: Society of Antiquaries, 1823.

Ostovich, Helen and Elizabeth Sauer, eds. Reading Early Modern Women: An Anthology of Texts in Manuscript and Print, 1550-1700. London: Routledge, 2004.

Parry, Glyn. The Arch-Conjuror of England: John Dee and Magic at the Courts of Renaissance Europe. New Haven: Yale University Press, forthcoming 2010.

Patai, Raphael. The Jewish Alchemists: A History and Source Book. Princeton: Princeton University Press, 1994.

Pollock, Linda. With Faith and Physic: The Life of a Tudor Gentlewoman, Lady Grace Mildmay, 1552-1620. London: Collins \& Brown, 1993.

Prest, Wilfrid R., ed. The Professions in Early Modern England. Beckenham: Crook Helm, 1987.

Principe, Lawrence M., ed. Chymists and Chymistry: Studies in the History of Alchemy and Early Modern Chemistry. Sagamore Beach: Science History Publications, 2007.

Prior, Mary, ed. Women in English Society, 1500-1800. London: Methuen, 1985.

Read, John. From Alchemy to Chemistry. Mineola: Dover Publications, 1995.

Rees, William. Industry Before the Industrial Revolution: Incorporating a Study of the Chartered Companies of the Society of Mines Royal and of Mineral and Battery Works, 2 Vols. Cardiff: University of Wales Press, 1968.

Reeves, Marjorie. The Influence of Prophecy in the Later Middle Ages: A Study in Joachimism. Oxford: Clarendon Press, 1969. 
Roberts, Julian and Andrew G. Watson, eds. John Dee's Library Catalogue. London: Bibliographical Society, 1990.

Rolleston, Sir Humphry Davy. The Cambridge Medical School: A Biographical History. Cambridge: Cambridge University Press, 1932.

Roob, Alexander. Alchemy \& Mysticism: The Hermetic Museum. Cologne: Tashen, 2001.

Schiebinger, Londa. The Mind Has No Sex?: Women in the Origins of Modern Science. Cambridge: Harvard University Press, 1991.

Slack, Paul. The Impact of Plague in Tudor and Stuart England. Oxford: Oxford University Press, 1985.

Snook, Edith. Women, Reading and the Cultural Politics of Early Modern England. Aldershot: Ashgate, 2005.

Spence, R.T. Lady Anne Clifford, Countess of Pembroke, Dorset and Montgomery (15901676). Thrupp: Sutton Publishing, 1997.

Stevenson, Jane and Peter Davidson. Early Modern Women Poets (1520-1700): An Anthology. Oxford: Oxford University Press, 2001.

Strong, Roy. The Cult of Elizabeth: Elizabethan Portraiture and Pageantry. London: Thames and Hudson, 1977.

- Gloriana: The Portraits of Queen Elizabeth I. New York: Thames and Hudson, 1987.

Tanner, Marie. The Last Descendent of Aeneas: The Hapsburgs and the Mythic Image of the Emperor. New Haven: Yale University Press, 1993.

Taylor, F. Sherwood. The Alchemists. London: Scientific Book Club, 1950.

Thomas, Keith. Religion and the Decline of Magic: Studies in Popular Beliefs in Sixteenth- and Seventeenth-Century England. Oxford: Oxford University Press, 1997.

Thorndike, Lynn. History of Magic and Experimental Science, 8 Vols.. New York: Columbia University Press, 1923-58.

von Franz, Marie-Louise, ed. Aurora Consurgens: A Document Attributed to Thomas Aquinas on the Problem of Opposites in Alchemy. London: Routledge \& Kegan Paul, 1966.

Waller, Gary F. Mary Sidney, Countess of Pembroke: A Critical Study of Her Writings and Literary Milieu. Salzburg: University of Salzburg, 1979.

Webster, Charles. Paracelsus: Medicine, Magic and Mission at the End of Time. New Haven: Yale University Press, 2008. , ed. Health, Medicine and Mortality in the Sixteenth Century. Cambridge: Cambridge University Press, 1979. 
Wiffen, J.H. Historical Memoirs of the House of Russell from the Time of the Norman Conquest, Vol. 2. London: Longman, Rees, Orme, Brown, Green, and Longman, 1833.

Williams, Franklin B. Index of Dedications and Commendatory Verses in English Books Before 1641. London: Bibliographical Society, 1962.

Williams, Gerhild Scholz and Charles D. Gunnoe. Paracelsian Moments: Science, Medicine \& Astrology in Early Modern Europe. Kirksville: Truman State University Press, 2002.

Williamson, George. Lady Anne Clifford Countess of Dorset, Pembroke and Montgomery, 1590-1676. Her life, letters and work, extracted from all the original documents available, many of which are here printed for the first time. Kendal: Titus Wilson and Son, 1922.

- George, Third Earl of Cumberland (1558-1605): His Life and His Voyages. Cambridge: Cambridge University Press, 1920.

Wells, Robin Hedlam. Spenser's Faerie Queene and the Cult of Elizabeth. London: Croom Helm, 1983.

Woods, Susanne. Lanyer: A Renaissance Woman Poet. Oxford: Oxford University Press, 1999.

Yates, Frances. Astraea: The Imperial Theme in the Sixteenth Century. London: Pimlico, 1993.

—. Giordano Bruno and the Hermetic Tradition. London: Routledge, 2002.

- The Occult Philosophy and the Elizabethan Age. London: Routledge, 2002.

Young, John T. Faith, Alchemy and Natural Philosophy: Johann Moriaen, Reformed Intelligencer, and the Hartlib Circle. Aldershot: Ashgate, 1998.

Zinsser, Judith P., ed. Men, Women, and the Birthing of Modern Science. De Kalb: Northern Illinois University Press, 2005.

\section{Online Databases}

British Library, English Short Title Catalogue,

[http://estc.bl.uk].

McLean, Adam, The Alchemy Web Site,

[http://www.alchemywebsite.com].

Various, Encyclopedia Britannica,

[http://www.britannica.com]. 
Various, Oxford Dictionary of National Biography, Oxford, online edn.,

[http://www.oxforddnb.com].

\section{Unpublished Theses}

Jayne Elisabeth Archer, "Women and Alchemy in Early Modern England" (PhD dissertation, Cambridge University, 1999).

James Campbell, "The Alchemical Patronage of Sir William Cecil, Lord Burghley" (Master's thesis, Victoria University of Wellington, 2009). 